\title{
Beneath the Gypsum Dunes: Cenozoic History of Wind and Water from a Core Drilled at White Sands, New Mexico
}

Jackson Bentley Jakeway

West Virginia University, jbj0003@mix.wvu.edu

Follow this and additional works at: https://researchrepository.wvu.edu/etd

Part of the Geology Commons, Sedimentology Commons, and the Stratigraphy Commons

\section{Recommended Citation}

Jakeway, Jackson Bentley, "Beneath the Gypsum Dunes: Cenozoic History of Wind and Water from a Core Drilled at White Sands, New Mexico" (2019). Graduate Theses, Dissertations, and Problem Reports. 4083. https://researchrepository.wvu.edu/etd/4083

This Thesis is protected by copyright and/or related rights. It has been brought to you by the The Research Repository @ WVU with permission from the rights-holder(s). You are free to use this Thesis in any way that is permitted by the copyright and related rights legislation that applies to your use. For other uses you must obtain permission from the rights-holder(s) directly, unless additional rights are indicated by a Creative Commons license in the record and/ or on the work itself. This Thesis has been accepted for inclusion in WVU Graduate Theses, Dissertations, and Problem Reports collection by an authorized administrator of The Research Repository @ WVU. For more information, please contact researchrepository@mail.wvu.edu. 
Beneath the Gypsum Dunes:

Cenozoic History of Wind and Water from a Core Drilled at White Sands, New Mexico

Jackson Bentley Jakeway

Thesis submitted to the Eberly College of Arts and Sciences at West Virginia University

Master of Science in Geology

Kathleen Benison, Ph.D., Chair Joe Donovan, Ph.D.

Amy Weislogel Ph.D.

Department of Geology and Geography

Morgantown, West Virginia 2019

Keywords: Sedimentology, White Sands, New Mexico, Evaporites, Gypsum, Pleistocene Copyright 2019 Jakeway 


\begin{abstract}
Beneath the Gypsum Dunes:

Cenozoic History of Wind and Water from a Core Drilled at White Sands, New Mexico
\end{abstract}

Jackson Jakeway

White Sands, New Mexico is the largest gypsum dune field on planet Earth, the result of reworking of gypsum deposits. The dunes have been well studied, but the Cenozoic history preceding the formation of the dune field has been poorly studied. A core drilled to a depth of $192 \mathrm{ft}(58.5 \mathrm{~m})$ beneath the modern dune field contains deposits from saline lakes, sandflats, perennial freshwater lakes, perennial brackish to saline lakes, and saline mudflats.

The core is composed of bottom-growth bedded gypsum, gypsum sandstone and siltstone, mixed siliciclastic-gypsum sandstones and siltstones, laminated siliciclastic mudstones, gypsum mudstones, and carbonate mudstones. Bottom-growth bedded gypsum was precipitated from saline lakes. Gypsum sandstones and siltstones were deposited by eolian processes. Mixed siliciclastic-gypsum sandstones and siltstones were deposited during periods of increased surface water inputs. Laminated siliciclastic mudstones were deposited in perennial freshwater lakes. Calcite mudstone containing charophytes and ostracods were deposited in shallow, perennial brackish to saline lakes. Gypsum mudstones indicate either shallow saline lakes or saline mudflats. Wavy lamina, climbing ripple cross-bedding, and dewatering structures in gypsum mudstones are evidence for rapid deposition of sediment by shallow, decelerating surface waters such as sheetfloods. Mudcracks and eolian reworked gypsum grains are evidence for subaerial exposure. Black beds, possibly manganese oxides, were present at two depths in the core.

Abundant displacive gypsum is interpreted as evidence for extensive saline groundwaters. Gypsum grain size and shape provide insight into production and subsequent transport of grains. Gypsum sandstones in the upper $80 \mathrm{ft}$ (24.4 m) were commonly composed of very lightly reworked gypsum grains displacive in origin and are evidence for saline mudflats and subsequent subaerial exposure. The high porosity of these units indicates that a large quantity of fine-grained sediment was deflated.

Seeds and other organic material were found throughout the core but were most abundant in the upper $80 \mathrm{ft}(24.4 \mathrm{~m})$ of core. A radiocarbon age date of $22 \mathrm{ka}$ was determined from a seed at 35.4' $\mathrm{ft}$ depth. Although the timespan of deposition of the core sediments is not known, it is estimated that the sediments at the base of the core may be as old as $\sim 200 \mathrm{ka}$, due to the diverse assemblage of megafauna fossils found throughout White Sands and Bull Lake Glaciation.

Sediment in the White Sands Core was deposited from perennial and ephemeral saline lakes, sandflats, perennial freshwater lakes, perennial brackish to saline lakes, and saline mudflats. There was abundant evidence for eolian processes. Two periods of perennial freshwater lake deposition and several saline lake deposits, as well as common eolian deposits strongly suggest fluctuations in climatic humidity and aridity during the Pleistocene. 


\section{Acknowledgments}

I would like to thank Dr. Kathy Benison for her insight, encouragement, and lightspeed return of my rough drafts. I'd also like to thank fellow students and friends including Sofia Andeskie, Luke Fritz, Shelby Isom, Bradley Smith, and Jonathan Johnson for help, support, and a few beers. Thanks to my mom and sister for support, both mental and occasionally financial, over the past few years. A big shout out to Dr. Joe Donovan for our weekly squash games and the opportunity to become acquaintances with his birds, Beta and Tuko. Thank you to Dr. Amy Weislogel for being on my committee. Another thanks to David Bustos and Patrick Martinez from White Sands National Monument. A final thanks to the staff at the USGS Core Research Center in Denver. Funding for this thesis was provided by US Department of Interior grant P18AC00211 awarded to David Bustos and Kathleen Benison. 


\section{Table of Contents}

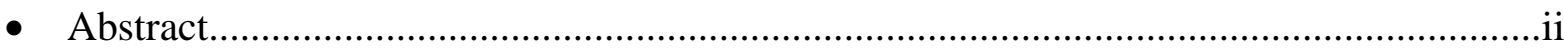

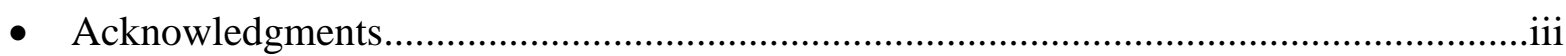

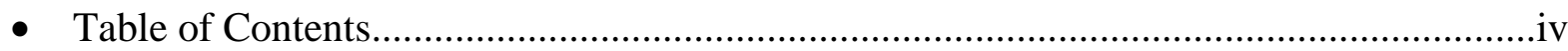

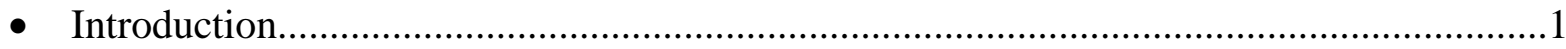

○ Overview …

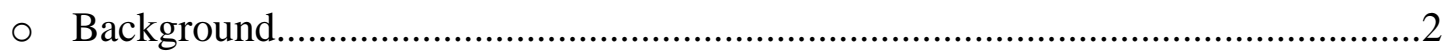

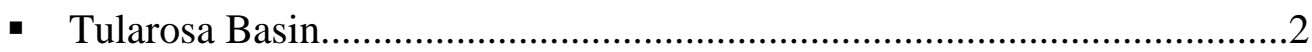

- Modern White Sands geology..................................................................

- White Sands core MW-12-11_....................................................................

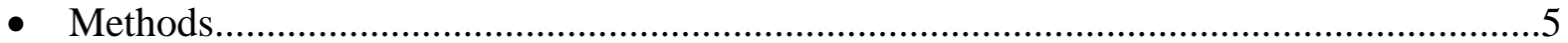

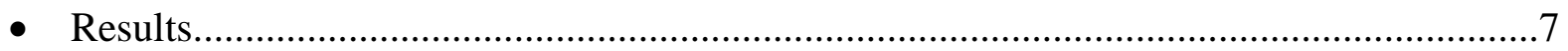

○ Summary of White Sands Core MW-12-11_.....................................................

○ Lithological Descriptions and Interpretations........................................................

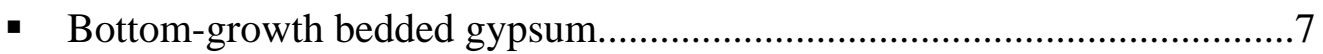

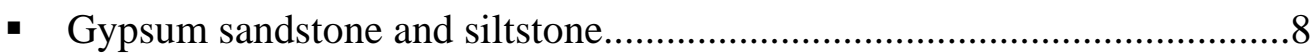

- Mixed siliciclastic-gypsum sandstone and siltstone.....................................10

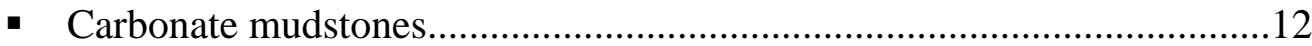

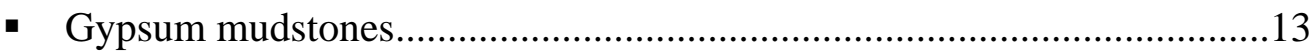

- Laminated siliciclastic mudstones.............................................................

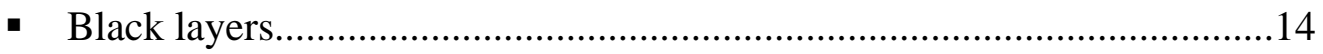

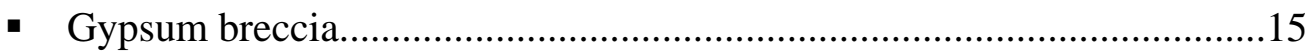

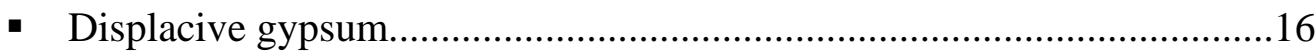

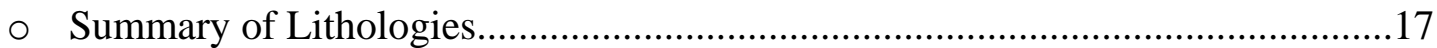

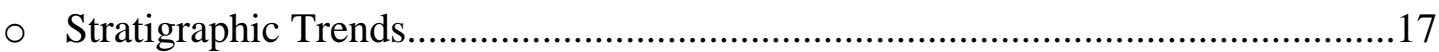

- 192.3 - $183.0 \mathrm{ft}$ - Perennial Freshwater Lake? Displacive Gypsum.......18

- 179.1 - $129.0 \mathrm{ft}$ - Saline Lakes, Sandflats, and Mudflats..................19

- 129.4 - $103.1 \mathrm{ft}$ - A Perennial Freshwater Lake and Return to Gypsum Production ....................................................20

- 103.1 - $84.0 \mathrm{ft}$ - Deflation of Previously Deposited Gypsum in Sandflats

- 84.0 - $25.0 \mathrm{ft}$ - Perennial Brackish to Saline Lakes, Saline Groundwaters,

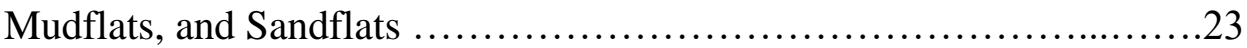

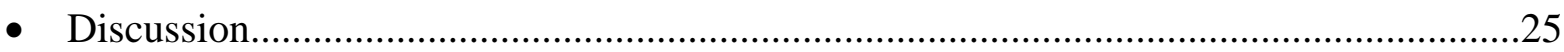

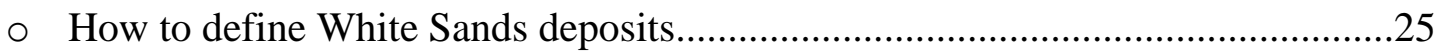

○ Lake Otero, a longer history than previously described..........................................28

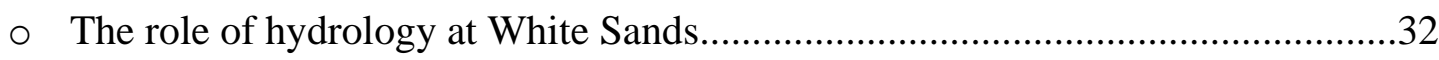

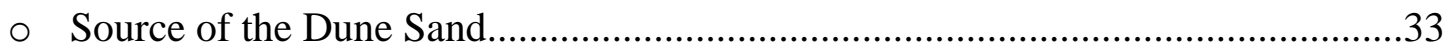

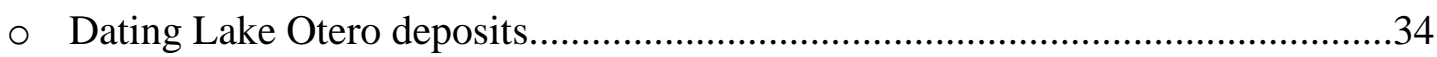


○ Comparison with other southwestern USA Pleistocene lake deposits....................36

○ Future studies and challenges associated with White Sands..............................37

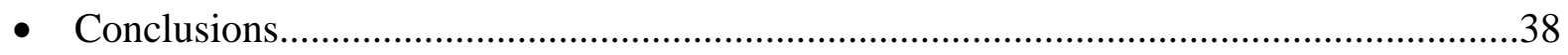

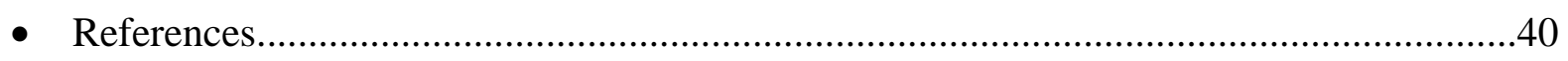

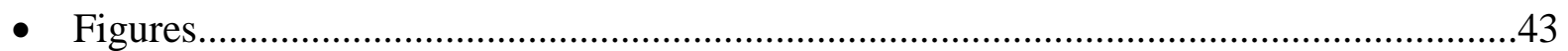

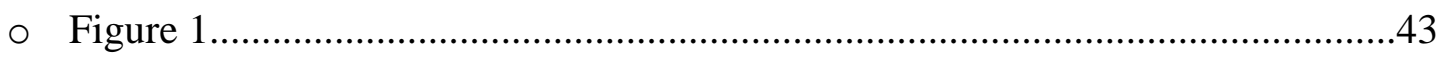

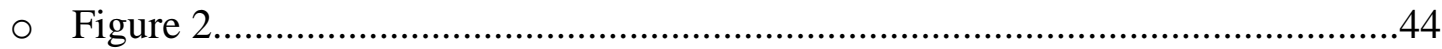

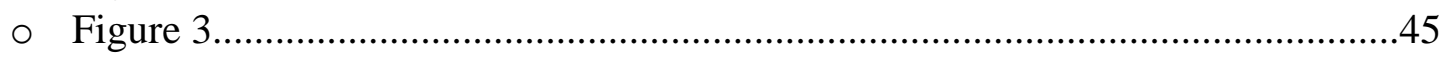

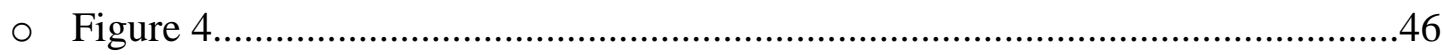

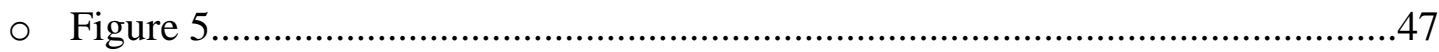

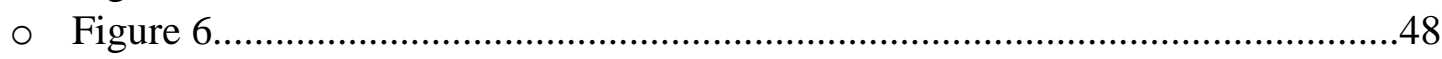

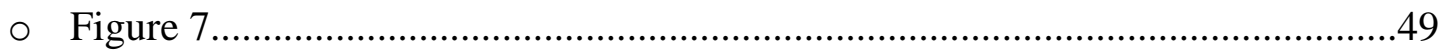

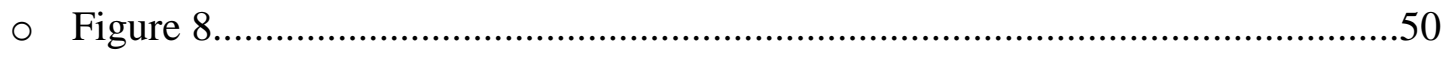

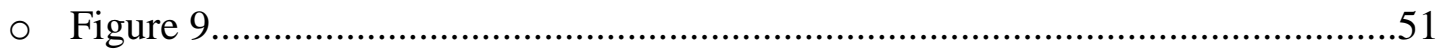

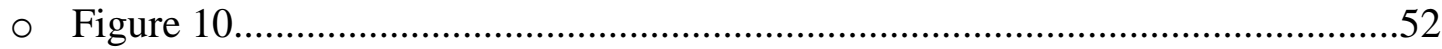

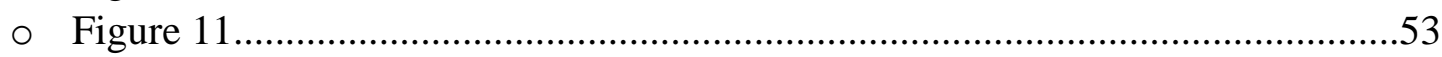

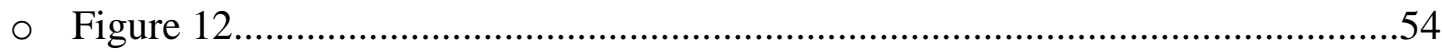

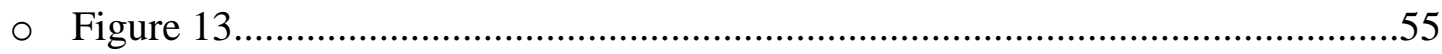

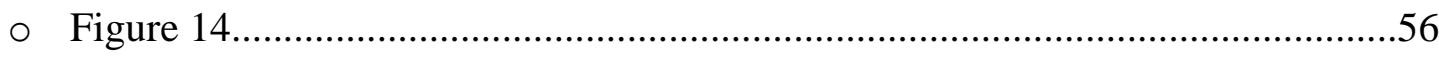

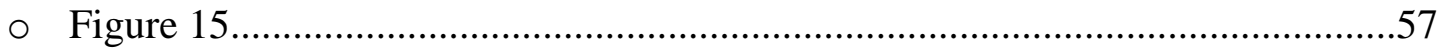

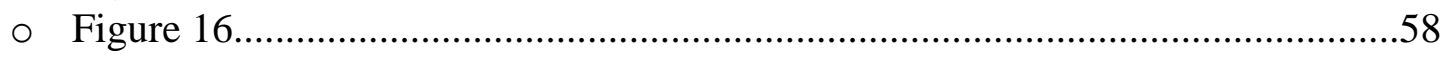

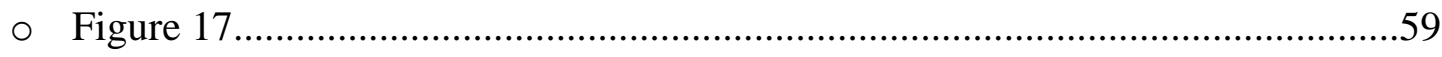

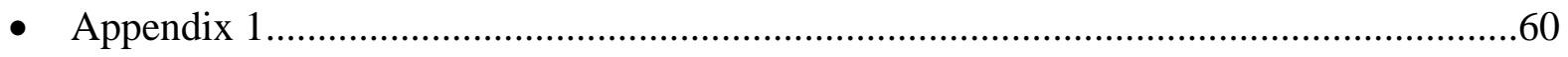

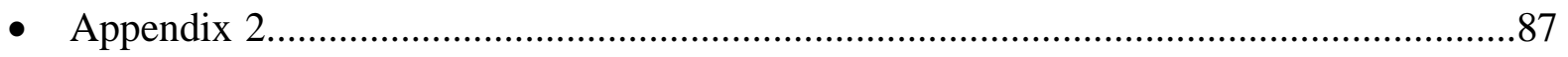




\section{Introduction}

\section{Overview}

White Sands, New Mexico is well known for its gypsum sand dunes, the largest gypsum sand dune field on the planet. The White Sands area also contains Alkali Flat and ephemeral Lake Lucero. Together, Lake Lucero, Alkali Flat, and the dunes constitute gypsum sandflats, mudflats, ephemeral saline lakes, and subaerial dunes, which occupies an area of approximately 386 square miles $\left(621 \mathrm{~km}^{2}\right)$. The eolian processes of the gypsum sand dunes have been well studied (McKee, 1966; McKee and Moiola, 1975; Kocurek et al., 2007; Ewing and Kocurek, 2010; Jerolmack et al., 2011). It has been suggested that gypsum is sourced from both modern gypsum production on Alkali Flat and Lake Lucero and deflation of gypsum deposited by a large Pleistocene lake, Lake Otero (Allmendinger, 1971). However, no detailed study of the gypsum source has been conducted.

The Cenozoic history of sedimentation at White Sands is not well known. A large perennial lake, Lake Otero, may have occupied much of the basin floor (Herrick, 1904; Meinzer and Hare, 1915; Kottlowski, 1958; Seager et al., 1987; Hawley, 1993; Allen, 2009). Lake Otero's maximum extent is speculated to have covered 300 square miles $\left(482 \mathrm{~km}^{2}\right)$. Shorelines of Lake Otero have been loosely defined by a modern-day elevation of approximately 3,937 ft (1200 m) (Langford, 2002; Allen 2005). Gypsum deposits in the Tularosa Basin are generally attributed to precipitation from saline lake waters of Lake Otero and its desiccation. Observations regarding Lake Otero have been restricted to features exposed at the surface and, until this study, no subsurface data existed.

This study presents, for the first time, sedimentological documentation of the subsurface geology of White Sands by a core drilled to a depth of $\sim 192 \mathrm{ft}(58.5 \mathrm{~m})$ below the modern dune 
field. The goal of this work is to determine past depositional environments for White Sands, utilizing a detailed measured section, petrography, geochemical data, and limited radiocarbon dating.

\section{Background}

\section{Tularosa Basin}

White Sands is in the hydrologically closed Tularosa Basin of south-central New Mexico (Fig. 1). Tularosa Basin is approximately 150 miles (240 km) long and 60 miles wide $(97 \mathrm{~km})$. The basin floor is approximately 4,000 ft (1219.2 m) in elevation. White Sands National Monument encompasses about 225 square miles $\left(362 \mathrm{~km}^{2}\right)$ and offers the only public access to White Sands. The rest of Tularosa Basin is essentially owned by White Sands Missile Range and Holloman Air Force Base.

Tularosa Basin is the product of basin and range extension and Rio Grande rifting. Normal faults bound the basin along the western and eastern margins (Seager, 1987). Another fault runs north-south through the center of the basin but is poorly constrained (Newton et. al, 2014). The western boundary is formed by, from north to south, the Oscura Mountains, the San Andres Mountains, and the Organ Mountains. The eastern boundary is formed, from north to south, by Sierra Blanca and the Sacramento Mountains. The Jarilla Mountains mark part of the southern boundary but do not entirely close Tularosa Basin, which merges with Hueco Bolson. These mountain ranges have elevations of $\sim 8,000 \mathrm{ft}$ ( $2438 \mathrm{~m}$ ), except for the 12,000-foot ( 3657 m) peak of Sierra Blanca. Numerous alluvial fans exist along the basin's east and west sides. Alluvial fans in the west are directly adjacent to White Sands and those to the east are $~ 18.5$ miles (30 km) away from White Sands. The San Andres, Oscuras, and Sacramento mountains are 
mostly composed of Paleozoic sedimentary rocks, including dolostones, limestones, siliciclastics, gypsum, and anhydrite (Stanesco, 1985). The Jarilla Mountains are composed of Paleozoic and Tertiary igneous rocks (Schmidt, 1964). A 5.6 ka lava flow, the Carrizozo basalt, lies $~ 15$ miles (24 km) north of White Sands (Dunbar, 1999).

The Camp Rice Formation, a mix of Pliocene to mid Pleistocene alluvial, fluvial, lacustrine, playa, and eolian deposits, occupies much of the basin floor south of White Sands (Seager, 1987). The Camp Rice Formation was deposited by the Rio Grande River and associated drainages before it was diverted west during the late Middle Pleistocene (Stuart and Willingham, 1984). South of White Sands, the Camp Rice Formation is exposed and sediments have been eroded to form quartz sand dunes (Seager, 1987).

\section{Modern White Sands Geology}

The 386 square miles $(621 \mathrm{~km})$ of the modern White Sands sedimentary system is composed of three facies; ephemeral Lake Lucero, Alkali Flat, and eolian dunes (Fig. 1). The modern gypsum dune field is thought to be approximately 7 ka based on OSL data from the eastern side of the dune field (Kocurek, 2007) and relationships with Paleoindian artifacts (Langford, 2002). McKee (1975) found 23 - $34 \mathrm{ft}(7-10 \mathrm{~m})$ of dune sand beneath the dune field. The dunes may have resulted from a step like drop of the water table causing deflation of gypsum (Langford, 2002; Kocurek, 2007).

Gypsum dunes at White Sands include barchan, parabolic, transverse, and dome types (McKee, 1966). Barchan dunes, stabilized by vegetation, are found to the south and eastern sides of the dune field (Ewing and Kocurek, 2010). Early diagenetic cements help stabilize the dunes

further (Fryberger and Schenk, 1988). Interdune deposits consist of gypsum sand lamina. Crinkly 
and more organic rich lamina are common in the upper part of interdunal sections (Kocurek, 2007). Different vegetation grows in interdunal areas including Indian ricegrass, alkali sacaton, and yucca (Fig. 2A).

Lake Lucero is an ephemeral lake. Flooding occurs after significant rain events and can last for hours to months (Fig. 2F). During desiccation, thick efflorescent crusts composed of mostly gypsum form (Fig. 2E). This crust is typically destroyed by deflation (Allmendinger, 1971). Wind-reworked gypsum grains ranging from fine sand to cobble size $\sim 0.02$ inch - $\sim 1$ inch $(0.1 \mathrm{~mm}-30 \mathrm{~mm})$ are found at the surface. Gypsum crystals are exposed at the surface, but their age is difficult to constrain. Gypsum could be recent, modern, or both.

West of the dune field lies Alkali Flat, which consists of wet mudflats, dry mudflats, sandflats, and scattered dunes (Fig. 2B, C, D). Flooding occurs in depressions created by deflation (Langford, 2002). Efflorescent crusts form as the result evaporative pumping of shallow, saline groundwater towards the surface when the lake is desiccated (Smoot and Castens - Seidell, 1994) (Fig. 2C). These crusts are ephemeral, either dissolved by later rainstorms or blown away. Vegetation on Alkali Flat is sparse (Fig. 2C, D). Gypsum sand is commonly deposited on the downwind side of vegetation, forming sand sheets (Fig. 2D).

\section{White Sands Core MW-12-11}

White Sands Core MW-12-11 was drilled through an interdunal area of the modern dune field within White Sands National Monument by the United States Geological Survey and National Park Service in late 2012. The location of coring is indicated on Figure 1. The core was drilled to a depth of $192.3 \mathrm{ft}(58.4 \mathrm{~m})$, and $85.5 \%$ of this depth was recovered. Depths of 192.3 $25 \mathrm{ft}(58.6 \mathrm{~m}-7.6 \mathrm{~m})$ were retained; the top $25 \mathrm{ft}(7.6 \mathrm{~m})$ was discarded and simply described as 
gypsum sands and muds. Freshwater was used as the drilling fluid due to restrictions from the National Park Service and Otero County. This freshwater may have removed any extremely soluble minerals such as halite during drilling. A simple stratigraphic column was made and published in an official government report, but no other data exists on the core (Newton et al., 2014). After drilling, the core was archived at the USGS Core Research Center in Denver, Colorado, where it was slabbed by staff. The core has been stored in boxes, unsealed and exposed to indoor conditions.

\section{Methods}

The core was studied in detail from July 24th - August 1st, 2018 at the USGS Core Research Center. Observations were made in hand sample and with a Fischer Scientific reflected light binocular microscope with 10x-30x magnification. The core had been stored unsealed for $\sim 6$ years and some alteration was evident since the core was slabbed. Comparison of photos taken at the core lab in 2018 to those taken by the USGS staff, immediately after the time of slabbing, in late 2012 or early 2013, revealed that cracking, warping, and localized iron and sulfur staining had occurred. Significant efflorescent salt precipitates, mostly gypsum, have formed on the surface of the core. These precipitates typically were millimeter or smaller in size, white to brown, donut shaped bumps and were most abundant on fine-grained sediment. Some delicate gypsum fibers also precipitated on the core surface in places.

The core was divided into 93 separate units based on lithology described at the Core Research Center. Core slab photographs were taken with an iPhone SE, Canon DSLR, and Nikon D7100. Representative samples were cut for thin section preparation by the USGS CRC staff. A 
total of 36 samples were taken for thin section petrography, XRD analysis, and C-14 radiometric dating.

Thirty standard-format (1.06 x $1.81 \mathrm{in} ; 27$ x $46 \mathrm{~mm})$ thin sections were prepared by Spectrum Petrographics, Inc. Sampling size limits of the USGS led to some samples only covering approximately half of the thin section glass. Thin section preparation included vacuum impregnation with blue epoxy and polishing to a thickness of $0.03 \mathrm{~mm}$. Thin sections were observed with an Olympus SZx12 stereo microscope (magnification range 6.3 - 63x) and an Olympus BX511r research petrographic microscope (magnification range 20 - 2,000x). Both microscopes are equipped with transmitted, reflected, and polarized light sources.

Photomicrographs were captured with SPOT5 digital imaging system. Petrographic observations included sedimentary structures, sedimentary textures, mineral composition, cements, and fossils.

Three samples taken at depths of $190.2 \mathrm{ft}(60 \mathrm{~m}), 122.4 \mathrm{ft}(37.3 \mathrm{~m})$, and $59.1 \mathrm{ft}(18 \mathrm{~m})$ were analyzed by XRD to identify minerals. Samples were selected based upon uniqueness of units and difficulty identifying minerals in hand sample at the core lab. Samples were crushed with a mortar and pestle, packaged in small glass vials and sent to K-T Geoservices for bulk mineralogy and (<4 micron) clay mineral analysis. Data was summed to $100 \%$ of the crystal fraction, percentages of one mineral depend on percentage of the others; therefore, mineral abundances are relative.

Three samples taken from depths of $177.8 \mathrm{ft}(54.3 \mathrm{~m}), 81.9 \mathrm{ft}(24.0 \mathrm{~m})$, and $35.3 \mathrm{ft}$ (10.8 m) were sent to Dr. Vance Holliday of the University of Arizona for 14C radiometric dating. Samples were prepared by Brendan Fenerty and analyzed by the University of Arizona AMS lab. The samples from $177.8 \mathrm{ft}(54.2 \mathrm{~m})$ and $81.9(24.0 \mathrm{~m}) \mathrm{ft}$ were taken from black beds thought to 
be charcoal. The sample from $35.3 \mathrm{ft}(10.8 \mathrm{~m})$ was one seed plucked from the core using tweezers. Uncalibrated and calibrated ages were provided. OxCal 4.2 / IntCal13 atmospheric calibrations were used.

Field work was performed at White Sands over the course of a 9-month internship from August of 2016 - May of 2017 and during a 4-day field trip in the spring of 2018.

Sedimentological observations were made of Lake Lucero, Alkali Flat, and the dunes for comparative sedimentology.

\section{Results}

\section{Summary of White Sands Core MW-12-11}

Gypsum was the most common mineral in the core, found in nearly all units. Fifty-five percent of the core was composed of nearly pure (>90\%) gypsum sandstones and siltstones. Almost all other units contained gypsum sand and silts. Other lithologies included bedded bottom-growth gypsum, mixed siliciclastic-gypsum sandstones and siltstones, carbonate mudstones, laminated siliciclastic mudstones, gypsum mudstones, gypsum breccia, and suspect manganese oxide layers. Diagenetic features included abundant displacive gypsum and gypsum veins. Sharp contacts between units were common. $\mathrm{HCl}$ was used to identify carbonate minerals and it was typically possible to distinguish reactions with cement and grains using the available microscope. Figure 3 presents a simplified measured section.

\section{Lithological Descriptions and Interpretations}

\section{Bedded Bottom-Growth Gypsum Lithology - Saline Lake Lithofacies}


Two units containing vertically oriented gypsum crystals, 0.2 - 1 in $(5-25 \mathrm{~mm})$ in height, were found at depths of $174.4 \mathrm{ft}(53.2 \mathrm{~m})$ and $167.8 \mathrm{ft}(51.1 \mathrm{~m})$ in the core (Fig. 4). Bedded bottom-growth gypsum composed $0.1 \%$ of the core. Beds were slightly undulating. Crystals were prismatic in shape. Some had a pointed base and widened upwards creating a V-shape. Some crystals were twinned, creating a swallow-tail shape. Vertical orientation, widening upwards, and swallow tail shapes are characteristic habits of gypsum crystals precipitated at the sediment - water interface in saline lakes (Schreiber and Tabakh, 2001; Benison et. al., 2007; Benison, 2019).

Vertically-oriented, swallowtail, and v-shaped crystals found in the White Sands core are interpreted to have precipitated from gypsum-saturated surface waters in saline lakes. One of the bedded bottom-growth gypsum units contained several beds of vertically-oriented gypsum crystals separated by coarse, abraded gypsum sand layers. This is interpreted as the result of several flooding, evapoconcentration, desiccation, and deflation cycles.

\section{Gypsum Sandstone and Siltstone - Sandflat Lithofacies}

Gypsum sandstones and siltstones were the most common lithology, comprising 55\% of the core. Grain size ranged from silt to very coarse sand. These units are white to grey in color (Fig. 5). A wide variety of grain shapes were present and included nearly original crystal shapes, platy, lenticular, and blocky (Fig. 6). Nearly perfect lenticular gypsum grains were the most common grain shape in the upper $80 \mathrm{ft}$ (24.4 m) of core. Some gypsum grains were heavily abraded while others showed little to no abrasion. Porosity ranged from 0 - 40\%. Sedimentary structures included wavy discontinuous lamina, planar lamina, cm-scale bedding, bimodal grain size distribution, cross-lamina bedding, root traces, and burrows. Bimodal grain size distribution 
was typically composed of larger, angular grains and finer, less angular grains. Many units contained fibrous, brown plant matter and seeds. Seeds were sometimes partially or entirely replaced by pyrite. Petrography revealed some gypsum sand grains had parallel brown bands, likely mud and fluid inclusions included in its structure. One gypsum siltstone unit contained several centimeter-scale, diagenetic gypsum veins.

Lithological features of the gypsum sandstones and siltstones are interpreted as being deposited in sandflats through eolian processes and subaerial exposure. The grain shape provides information about the origin and history of gypsum. Blocky, abraded grains would have been transported longer distances, which is interpreted as evidence that a greater area of surface was subaerially exposed. Grains with identifiable crystal shapes were deposited near where the gypsum originally precipitated. Angular grains suggest intermediate transport distances. Grains with parallel brown bands are interpreted to have been originally precipitated as bottom growth gypsum and reworked by wind.

In the upper $80 \mathrm{ft}$ (24.4 m) of core, gypsum sandstones and siltstones composed of nearly perfect lenticular crystals were abundant. These grains were commonly aligned horizontally. It is likely these crystals were originally precipitated as displacive gypsum from saline groundwaters. The delicate points of grains were commonly preserved, and grains were generally unabraded or very lightly abraded. The horizontal alignment of grains suggests that they may not have been transported at all, but instead, fine-grained matrix that the gypsum precipitated in was deflated and the displacive crystal grains settled which caused the horizontal alignment.

Gypsum sands and silts can be diagnostic of depositional environment and eolian transport distances. Jerolmack et al. (2011) found that the grain size decreases and grains become more equant in the first few miles of transport. At approximately 3.25 miles $(5.2 \mathrm{~km})$ downwind, 
grains were well sorted and equant. Sand grains in the dune field were typically 0.3 in $(0.8 \mathrm{~mm})$ or less (Jerolmack et al., 2011). Nearly intact crystal grains found in the core with little abrasion suggest that these grains have been transported very short distances and gypsum production occurred relatively nearby where grains were deposited. In some cases, well preserved crystal shapes allow for the distinction between bottom-growth and displacive gypsum grains. Further transport of grains leads to increased blockiness. Finding well sorted, fine, blocky grains could indicate a larger transport distance and a more distal source or, alternatively, local reworking by mixed directional winds.

\section{Mixed Siliciclastic-Gypsum Sandstone and Siltstone - Increased Surface Water Input/ Perennial Freshwater Lake Lithofacies}

Mixed siliciclastic-gypsum sandstones and siltstones were the second most abundant lithology, comprising $13.6 \%$ of the core. Siliciclastic mineral grains composed $10-40 \%$ of grains in most of these units. Only at the base of the core were there siltstones composed of nearly pure siliciclastic minerals. The core at $190.2 \mathrm{ft}(58.0 \mathrm{~m})$ returned $52 \%$ quartz and feldspars, $43.5 \%$ clays including illite, smectite, and chlorite, $3 \%$ dolomite and calcite and $1.5 \%$ gypsum (appendix 3). These units were red, red-grey, and tan (Fig. 7). Grain size typically ranged from fine sand to silt. Grains were sub-rounded - rounded and moderately - well sorted. Sedimentary structures included wave ripple cross lamina, wavy discontinuous lamina, climbing ripple cross lamina, planar lamina, and rare root traces. Siliciclastic pure units at the base of the core coarsened upward. Dewatering structures were found in one unit, at $121.0 \mathrm{ft}(36.9 \mathrm{~m})$. Plant and seed material were found in some units. Lenticular gypsum crystals, $0.01-0.02$ in $(0.5$ $\mathrm{mm}-3.0 \mathrm{~mm}$ ) in size, were found in some units. Porosity ranged from an estimated $0-\sim 30 \%$. 
Calcite nodules were found in one unit at $80.3 \mathrm{ft}(24.5 \mathrm{~m})$ and several nodules had a segmented, gastropod like shape. Some units were cemented with calcium carbonate.

Mixed siliciclastic-gypsum sandstones and siltstones are interpreted to represent periods of enhanced rainfall and sheetfloods, which transported sediment to the basin floor from the surrounding mountain ranges. Siliciclastic pure units from $\sim 190.2-180.0 \mathrm{ft}(60.0-54.9 \mathrm{~m})$ are interpreted to have been deposited in a perennial freshwater lake. One possibility is that these deposits may be the result of sedimentation in a wet period where a large, perennial freshwater lake existed that shrank in size as conditions became more arid. The gradational coarsening upwards supports that coarser material was deposited as water depths shallowed and that the recession of the lake was a gradual transition. Another possibility is that these deposits formed as a small pond that marked the termination of a stream.

Mixed siliciclastic - gypsum sandstones and siltstones in the core, are interpreted as evidence for increased surface water input and wetter conditions which caused transport of grains to the basin floor. The well sorted nature of many of these deposits suggests that eolian processes may have reworked material originally transported through streams during wetter periods. Rare wavy, discontinuous laminae and climbing ripple laminae are interpreted as evidence for movement of shallow surface water, such as occasional sheet floods (Fig. 7). Dewatering structures further support shallow surface waters and desiccation (Fig. 7). Lenticular gypsum crystals are interpreted as an early diagenetic feature, precipitating displacively from saline groundwater in the shallow subsurface.

Above $185 \mathrm{ft}$ (56.4 m), siliciclastic sand and silt were mixed with gypsum but below 185 $\mathrm{ft}(56.4 \mathrm{~m})$ contained little to no gypsum. The stratigraphically bottommost gypsum grains were identified at $187 \mathrm{ft}(57.0 \mathrm{~m})$. One and half percent gypsum was detected by XRD. This minor 
gypsum likely formed from desiccation after coring. This suggests the base of the core may represent sediment deposited before significant gypsum precipitation initiated in the basin.

\section{Carbonate Mudstones - Perennial Brackish to Saline Lake Lithofacies}

Several carbonate mudstones were found in the core, a 1 -in $(2.54 \mathrm{~cm})$ unit at $189.3 \mathrm{ft}$ $(57.7 \mathrm{~m})$, a $6 \mathrm{ft}(1.83 \mathrm{~m})$ thick unit from 119.1 - $113.6 \mathrm{ft}(36.3-34.6 \mathrm{~m})$, and several smaller carbonate mudstones from depths of 85.0 - $80.0 \mathrm{ft}$ (25.9 m - $24.4 \mathrm{~m})$ (Fig. 8). Carbonate mudstones comprised $5.6 \%$ of the core. The units between $83.5 \mathrm{ft}(25.5 \mathrm{~m})$ and $82.5 \mathrm{ft}(25.1 \mathrm{~m})$ were separated by missing core. Units were pale tan to pale red in color. While no carbonate grains were visible, they were distinguished from other mudstones by their moderate to vigorous reaction with $\mathrm{HCl}$. The unit at $189.3 \mathrm{ft}$ had a convolute structure. The unit at $119.1 \mathrm{ft}(36.3 \mathrm{~m})$ had a massive texture. Thin section petrography from $117.1 \mathrm{ft}(35.7 \mathrm{~m})$ showed an abundance of eye shaped textures like those found in the laminated siliciclastic mudstone units. The unit at $83.5 \mathrm{ft}(25.5 \mathrm{~m})$ contained woody plant fragments and lenticular shaped gypsum crystals 0.01 inches - 0.02 inches (1 - $4 \mathrm{~mm}$ ) in length. Abundant ostracod fragments, charophytes, and woody plant material and seeds were observed in the unit at $82.7 \mathrm{ft}$ (25.2 m; Fig. 8B). This unit also contained lenticular gypsum crystals.

The thin, convoluted carbonate mudstone unit at $189.3 \mathrm{ft}(57.7 \mathrm{~m})$ is interpreted as evidence for increased chemical concentration of waters leading to precipitation of carbonate minerals. The convolute structure is interpreted as a dewatering structure related to desiccation. It is also possible that this convolute feature formed during compaction of sediments.

The unit from $119-113.6 \mathrm{ft}(36.3-34.6 \mathrm{~m})$ is interpreted as being carbonate and gypsum precipitated in shallow saline waters or as saline mudflat deposits. There was a 1-foot $(0.3 \mathrm{~m})$ 
bed of gypsum sand and silt found in the middle of the unit which is interpreted as evidence for a period of subaerial exposure. The paucity of eolian gypsum except for the 1-foot $(0.3 \mathrm{~m})$ bed of gypsum in the middle of the unit suggests that this unit was subaqueously deposited.

The units from depths of $85.0-82.5 \mathrm{ft}(25.9 \mathrm{~m}-25.1 \mathrm{~m})$ are interpreted to have been deposited in a shallow perennial brackish to saline lake. Evidence for this includes aquatic fossils and carbonate deposits. Charophytes are plant like algae that can flourish in fresh to saline water (Soulié-Märsche, 2015). Finding seeds and organic material suggest a relatively shallow water depth with the possibility of plants growing either immersed or along a nearby shoreline. These carbonate deposits are relatively thin, suggesting a short period of deposition. Lenticular displacive gypsum crystals suggest that groundwater returned to saline conditions shortly after these units were deposited.

\section{Gypsum Mudstone - Saline Mudflat or Saline Lake Lithofacies}

Gypsum mudstones were found throughout the core and were typically less than 10 in (25 $\mathrm{cm}$ ) thick. Gypsum mudstones composed $6.5 \%$ of the core. They were white, grey, and pale red in color (Fig. 9). Gypsum mudstones were typically massive. Rare sedimentary structures included wavy laminae, planar laminae, burrows, and roots. Laminae were composed of gypsum silt. One unit formed intraclasts in the overlying unit (Fig. 9). These units were commonly covered with 0.01 inch $(0.2 \mathrm{~mm})$ or smaller precipitates that formed from desiccation of the core.

Gypsum muds can be deposited in ephemeral lakes, saline lakes, mudflats, and interdunes. Burrows and roots suggest subaerial exposure. Intraclasts have a slight curved texture, suggesting that they were originally mudcracked mud chips saturated with water and later desiccated. Wavy, silt lamina might indicate deposition through movement of shallow 
surface water. It's also possible that wavy, silt laminae are the remnants of efflorescent crusts, which trapped windblown gypsum silt before the efflorescent crust was destroyed. At modern White Sands, mudstones can be found in a wide range of environments. To interpret these gypsum mudstones, context of the surrounding units must be considered.

\section{Laminated Siliciclastic Mudstones - Perennial Freshwater Lake Lithofacies}

Laminated siliciclastic mudstones composed $5 \%$ of the core. Laminated siliciclastic mudstones were exclusive to a single $8 \mathrm{ft}$ (2.4 m) unit, from 129.4 - $121.5 \mathrm{ft}$ (39.4 m - $37.0 \mathrm{~m})$. Laminae ranged from dark grey to white in color and were prevalent through much of the unit (Fig. 10). XRD results from $122.4 \mathrm{ft}(37.4 \mathrm{~m})$ revealed a composition dominated by siliciclastics and clays, predominately illite and smectite and $<1.5 \%$ gypsum (Appendix 3 ). No reaction with HCL occurred. Some laminae were composed of silt grains while others were composed of organic material (Fig. 10). Root traces were also evident (Fig. 10). Several seeds were found throughout this unit. White, eye shaped textures $\sim 0.01$ inch $(0.2 \mathrm{~mm})$ in size were prevalent in thin section. Some of these eye shaped textures were replaced with pyrite. This unit had a gradational upper contact with mixed siliciclastic and gypsum sandstones above.

Laminated, siliciclastic mudstones are interpreted to have been deposited in a perennial freshwater lake. Burrows, root traces, and silty lamina suggest that lake waters may not have been deep. The undisturbed nature of lamina and fine-grained sediment are evidence for a low energy environment, distal from a sediment source. A paucity of gypsum and carbonate are interpreted as evidence for freshwater and enhanced surface water input, waters containing suspended material with little dissolved solutes. Given the amount of gypsum found below this unit, the paucity of gypsum also suggests older gypsum deposits were protected from erosion, 
likely by surface water, which helps support that these siliciclastic mudstones are lacustrine deposits. The pyritized nature of some of the white eye-shaped features suggest they may originally have been composed of some type of organic material. They are similar in shape to some seeds found in the core.

\section{Black Beds - Unknown Origin}

Two black beds were found at a depth of $177.7 \mathrm{ft}(53.9 \mathrm{~m})$ and $84.0 \mathrm{ft}(25.6 \mathrm{~m})$. were initially thought to be charcoal but after analysis were found to contain no carbon. Significant sulfur and iron staining occurred on exposed surfaces and cracks in these units (Fig. 11). Gypsum sands were encapsulated within one black bed. The black beds may be manganese oxides, which have been found exposed at the surface of White Sands (Vance Holliday, personal communication). Both units containing black layers were found stratigraphically near evidence for saline lakes, which suggest they may be related to change in hydrologic conditions.

\section{Gypsum Breccia - Unknown Origin}

One gypsum breccia unit was found in the core (Fig. 12). It is composed of gypsum crystals up to one inch in size within an iron and sulfur stained mud. Some crystals were vertically oriented, others were not vertically aligned. Other crystals had pointed tips. Some crystals had intercalated mud. This unit is underlain by 6 in $(15 \mathrm{~cm})$ of laminated siliciclastic and overlain by approximately $7 \mathrm{ft}(2.1 \mathrm{~m})$ of laminated siliciclastic mudstones. The crystals show some similarity to splayed bottom-growth gypsum observed in Salar Ignorado and Gorbea, Chile (Benison, 2019). 
The origin of these crystals is uncertain. The vertical orientation of some crystals may suggest they formed as bottom growth crystals. Mud trapped within the crystals may have occurred as the crystals precipitated as bottom-growth, but generally mud is incorporated along growth bands, such as sands found in some of the other gypsum grains in the core. It is such that mud was trapped within the crystals as they precipitated as diagenetic displacive gypsum. If the crystals are indeed bottom-growth in origin, this would suggest perennial freshwater deposition was interrupted by saline lake conditions before returning to freshwater deposits. Another possibility is that a saline spring discharged subaqueously and precipitated bottom-growth gypsum. There is little to suggest that the crystals were ever subaerially exposed. If they are diagenetic in origin, it would suggest that perennial freshwater deposition was never interrupted, and that the crystals formed later.

\section{Displacive Gypsum - Diagenetic Feature - Saline Groundwater Indicator}

Randomly oriented, lenticular gypsum crystals ranging in size from $0.1-0.2$ in $(0.2-4$

$\mathrm{mm}$ ) were found in the core in sand and mud matrix. Some crystals were twinned in an x pattern (Fig. 13). Crystals were found in a variety of lithologies including sandstones, siltstones, and mudstones. Crystals were generally clear in color. Displacive gypsum precipitates in random orientations. Some precipitated in small clusters and others were pervasive throughout a unit.

Displacive gypsum crystals precipitate from saline groundwaters as lenticular crystals and grow in the capillary, vadose, and phreatic zones and in algal mats (Schreiber, 2001). Lenticular gypsum crystals found in the core are interpreted as having precipitated directly from saline groundwaters in uncemented sediments. Many crystals were slightly imperfect which can 
present some challenges in determining if crystals are in original depositional position or not. Criteria to determine if they were in situ were perfect point terminations and random orientation.

\section{Summary of Lithologies and Lithofacies}

A range of environments are interpreted for the core, including saline lakes, sandflats, perennial freshwater lakes, perennial brackish to saline lakes, and saline mudflats (fig. 15). The amount of displacive gypsum indicates the importance of saline groundwaters at White Sands. One sequence of perennial freshwater lake deposits was confidently interpreted from the core, though some evidence near the base of the core suggests a second perennial freshwater lake may have occupied the basin. Direct evidence for saline lakes is rare, restricted to two units containing bottom-growth gypsum, but crystal shapes of reworked bottom-growth gypsum suggest these lakes were common. Evidence for brackish to saline lakes comes from carbonates and aquatic fossils and were most commonly found in the upper $85 \mathrm{ft}(25.9 \mathrm{~m})$. Evidence for eolian processes comes from the abundance of reworked gypsum sands.

\section{Stratigraphic Trends}

Shifts in climate are interpreted as the main driver of changes in depositional environments, particularly conditions becoming wetter or cooler, or both. The amount of gypsum in the core suggests that relatively arid climate conducive to gypsum precipitation was common but laminated siliciclastic mudstones interpreted as perennial freshwater lake deposits provide evidence that at least one, possibly two, perennial freshwater lakes occupied a large portion of the basin floor (fig. 15). 


\section{3 - 183.0 ft - Perennial Freshwater Lake?}

Mixed siliciclastic-gypsum sandstones and siltstones from 192.3 - $183.0 \mathrm{ft}$ (58.6 - 55.8 m) have been interpreted as a freshwater environment, near the termination of either a perennial or ephemeral stream during a transition to a more arid environment (fig 15). The base of this unit is composed of a silty mudstone. XRD analyses from sediment collected at $190.2 \mathrm{ft}$ (58 m) depth in core revealed approximately $52 \%$ mixed illite smectite, $11 \%$ illite and mica, $11 \%$ feldspars, $10 \%$ quartz, $5 \%$ calcite and dolomite, and $2 \%$ gypsum. There were abundant surface salts on the core and gypsum and calcite are likely the result of cementation or surface precipitation as the core desiccated after being drilled. Wavy laminae are interpreted as evidence for shallow surface waters. Sheet flooding is interpreted from climbing ripple lamina. The fine sand, silt, and mud grain size indicate low energy environments. Units were poorly sorted mud and silt grains which suggests they may have deposited from low energy waters. A thin convoluted, carbonate mudstone found at $189.3 \mathrm{ft}(57.6 \mathrm{~m})$ is interpreted as evidence that environmental conditions became more arid, with waters becoming concentrated enough to precipitate calcite. The convoluted structure is interpreted as a dewatering structure related to desiccation or due to compression of overlying units. Above the carbonate unit, mixed siliciclastic-gypsum sandstones and siltstones are interpreted to have been deposited mostly through eolian processes reworking older deposits elsewhere on the basin floor.

Climbing ripple cross-bedding, wavy ripple lamina, and dewatering structures indicate that occasional sheet floods occurred followed by desiccation. The first gypsum grains were noted around $187 \mathrm{ft}(57 \mathrm{~m})$ depth, evidence that gypsum production initiated on the basin floor. Gypsum grains were abraded and platy suggesting they had been transported from elsewhere on the basin floor. 


\section{1 - 129.0 ft - Saline Lakes, Sandflats, and Mudflats}

Gypsum is the most abundant mineral in units from $179.1-129.0 \mathrm{ft}(54.6-39.3 \mathrm{~m})$, most commonly as medium to coarse, angular to nearly original crystal shape gypsum sand. Bedded bottom-growth gypsum found at depths of $174 \mathrm{ft}(53 \mathrm{~m})$ and $167 \mathrm{ft}(50.9 \mathrm{~m})$ are clear indicators for saline lakes. Bottom-growth crystals are separated by gypsum sand layers indicating that lake size fluctuated, precipitating bottom-growth gypsum and exposing crystals for deflation before surface waters expanded again and precipitated more bottom-growth gypsum. Several units throughout these depths contained blocky, heavily reworked gypsum sands which suggest a large part of the basin floor was subaerially exposed, similar to the modern environment, and gypsum was transported large distances across the basin floor and that sandflat deposits were common. The distribution of grain size and shape again suggests that the size of the saline lake frequently fluctuated, exposing gypsum crystals precipitated from saline waters over large areas of the basin floor.

A mixed siliciclastic-gypsum sandstone was found at a depth of $140 \mathrm{ft}(42.6 \mathrm{~m})$ and siliciclastics only composed approximately $10 \%$ of the grains and have massive gypsum mudstones with root features overlying them from $141.4-140.2 \mathrm{ft}(43.1-42.7 \mathrm{~m})$. This is interpreted as a slightly wetter period with siliciclastics being transported in through increased surface water flows. The overlying mudstones are interpreted as having been deposited in a shallow, perennial saline lake with fine-grained gypsum precipitating and settling to the bottom, indicating a slightly wetter climate, though still arid. Similar vertical, root features were found in the overlying gypsum sandstone with approximately 10\% siliciclastic grains. From $140.2-129.4$ $\mathrm{ft}(42.7$ - $39.4 \mathrm{~m})$ gypsum sandstones with coarse to very fine sand size grains indicate subaerial exposure and eolian working in a sandflat environment where crystals had precipitated from 
saline waters nearby. Some crystals had partial swallowtail shapes or parallel bands of mud, indicating that a saline lake was precipitating bottom-growth gypsum nearby, but frequent subaerial exposure of crystals allowed for them to be reworked. Some grains had lenticular shapes, which suggests that the groundwater level had lowered enough to allow for some removal of the surface and displacive gypsum.

The bedded bottom-growth gypsum and gypsum sandstones and siltstones found between 179.1 - $129.9 \mathrm{ft}(54.6$ - $39.6 \mathrm{~m})$ were deposited in saline lakes that frequently fluctuated in size, sandflats, and saline mudflats. Both surface waters and groundwaters deposited gypsum found in these deposits. Much of the material was reworked by wind which supports fluctuating lake size. Mudstones and increased siliciclastics found in some units through these depths represent increased surface water transport and likely a larger lake. No aquatic fossils were found in thin section or hand sample suggesting that these lakes were typically inhospitable to aquatic life.

\section{4 - 103.1 ft - A Perennial Freshwater Lake and Return to Gypsum Production}

The onset of a perennial freshwater lake is marked by laminated siliciclastic mudstones found from depths of 129 - $121 \mathrm{ft}(39.3-36.9 \mathrm{~m})$. This unit is different than anything else in the core and represents an unusual environment in the Tularosa Basin during the Late Pleistocene. The paucity of carbonates and gypsum are interpreted as evidence for fluvial input providing a large supply of water low in chemical constituents. Root features, silt lamina, and seeds suggest that the lake was not particularly deep, though the relatively undisturbed lamina suggest that deposition in a low energy environment. Alternating light and dark lamina may represent a seasonal change or possibly short-term climate deviations. These laminated mudstone deposits 
are the strongest evidence for a large but shallow, fluvially fed, perennial freshwater lake which covered a large expanse of the basin floor.

The coarsening upwards transition at a depth of $\sim 121 \mathrm{ft}(36.9 \mathrm{~m})$ from laminated mudstones into $2 \mathrm{ft}(0.6 \mathrm{~m})$ unit of mixed siliciclastic-gypsum siltstone suggest a gradual transition from a large, perennial freshwater lake to a smaller, more saline system. Dewatering structures in siltstones just above the laminated mudstones suggest desiccation (Fig. 9). Cross laminated bedding and planar lamina above the dewatering structures are interpreted as evidence for eolian deposition. The mixed nature of these deposits suggest that gypsum may have begun precipitating elsewhere in the basin following the reduction of the perennial freshwater lake and was mixed with siliciclastics during transport. It is also possible the gypsum grains were reworked from older deposits.

A $6 \mathrm{ft}(1.8 \mathrm{~m})$ thick unit of calcareous mud lies above the mixed siliciclastic-gypsum siltstone at a depth of $119.1 \mathrm{ft}(36.3 \mathrm{~m})$. This mud had a moderate reaction with $\mathrm{HCl}$ which is interpreted as composition of both carbonate and gypsum. Concretions were found in this unit, generally a black center with orange and yellow staining surrounding it. Approximately 18 inches from the base of this unit a 1-foot $(0.3 \mathrm{~m})$ unit of very fine mixed siliciclastic-gypsum sand was found and is interpreted as material deposited by wind during a short period of exposure. A paucity of desiccation features, paucity of fossils, and the mixed calcareous and gypsum mud composition are interpreted as evidence for subaqueous deposition in shallow, saline lake. Thin sections did reveal an abundance of eye shaped features $\sim 0.2 \mathrm{~mm}$ in length, similar to those found in the laminated siliciclastic mudstones.

Approximately $8 \mathrm{ft}(2.4 \mathrm{~m})$ of core was missing, from $113-105.4 \mathrm{ft}(34.4-32.1 \mathrm{~m})$. Above the missing core, a 3-inch $(7.6 \mathrm{~cm})$ unit of brecciated gypsum or anhydrite clasts were 
found in a grey mud. Above that lie 18 inches $(45.7 \mathrm{~cm})$ of light grey, laminated gypsum muds. The tops of the muds form intraclasts in the unit above. Clasts have a slight curved shape suggesting that they formed as ripped up mud chips from a desiccated bed. Above this lies $2 \mathrm{ft}$ $(0.6 \mathrm{~m})$ of pale red, well sorted, very fine mixed siliciclastic-gypsum sandstones interpreted as reworking of materials deposited elsewhere in the basin, again evidence for exposure and eolian deposition. The abrupt, brecciated transition from these laminated gypsum muds to very fine sandstone is interpreted as evidence for a sudden change from wet to dry, a shallow saline lake to an arid, subaerially exposed environment.

Laminated siliciclastic mudstones, mixed siliciclastic-gypsum sandstones and siltstones, gypsum and calcium carbonate mudstones, and gypsum mudstones from $129.4 \mathrm{ft}$ - $103.1 \mathrm{ft}$ (39.4 - $31.4 \mathrm{~m}$ ) are interpreted as evidence for a perennial freshwater lake that transitioned to a fluctuating saline lake system. Laminated siliciclastic muds are evidence for a perennial freshwater lake. After the demise of the perennial freshwater lake, smaller saline lakes likely existed and frequently fluctuated in size. Gypsum sands of a variety of textures and grain sizes are evidence that gypsum production continued following the perennial freshwater lake stand.

\section{1 - 84.0 ft - Deflation of Previously Deposited Gypsum in Sandflats}

Gypsum sandstones and siltstones were abundant from depths of 103.1 - $84.0 \mathrm{ft}$ (31.4 $25.6 \mathrm{~m}$ ). These units ranged from very lightly abraded lenticular crystals to blocky silt grains (Fig. 7 and 8). Gypsum crystals were lenticular but sometimes abraded, interpreted as displacive in origin but having been lightly reworked. These grains were typically within a calcite cement. Bimodal grain size distribution, a criterion for eolian deposition, was prevalent in several units from these depths. A single 6-in $(15 \mathrm{~cm})$ mudstone unit with mudcracks that reacted slightly with 
$\mathrm{HCl}$ may have been deposited in a calcite precipitating lake that desiccated. Some lenticular crystals were unabraded and randomly oriented, interpreted that they formed as displacive gypsum and were in their original depositional position. The abundance of eolian gypsum is interpreted as sandflat deposits in an arid environment while displacive gypsum crystals indicate near-surface saline waters.

\section{0 - 25.0 ft - Perennial Brackish to Saline Lakes, Saline Groundwaters, Mudflats, and Sandflats}

The onset of a perennial brackish to saline lake is interpreted from carbonate mudstone units, containing ostracods and charophytes found at $84 \mathrm{ft}(25.6 \mathrm{~m})$. Ostracods and charophytes found in these carbonate mudstones are likely evidence for lacustrine deposition. The carbonate units also contained a significant quantity of seeds and plant fragments. Displacive gypsum precipitated after the calcite was deposited. A paucity of reworked gypsum grains suggest that previous gypsum deposits were protected, either covered by water or cemented early.

Gypsum sandstones and siltstones composed of mostly lenticular gypsum were common above $80 \mathrm{ft}$ (24.4 m). The lenticular crystals were lightly abraded to unabraded and maintained their delicate points. In some units there was bimodal grain size distribution of lenticular gypsum suggests different generations of displacive gypsum precipitation. Grains were commonly imbricated. Rare mud was captured between grains, which may be all that is preserved of the original host sediment. The nearly perfect crystal shapes of these deposits and imbrication are interpreted as evidence that the matrix that the crystals were precipitated in was deflated. Deflation caused minor abrasion of the crystal grains and the removal of sediment led to the grains settling in the imbricated alignment. When lenticular gypsum was the most abundant grain 
shape in a unit, it was rare to find other grain shapes. This helps support that lenticular gypsum grains were not transported, but instead, host sediment was deflated. The lenticular gypsum grains were likely deposited in a saline mudflat environment that experienced wet periods where gypsum precipitated and dry periods where host sediment was removed.

Another possibility for displacive gypsum is that they are in original depositional position. If displacive gypsum is in original depositional position, calcium carbonate interpreted as cement may have precipitated from lake waters before precipitation of displacive gypsum. The amount of displacive gypsum would've destroyed textures associated with original deposition. A single foraminifer was found in one of these units and provides support for lacustrine deposition followed by precipitation of displacive gypsum. It is also possible that the foraminifer was blown in. This depositional environment may have been a long-lived calcite producing lake, that frequently shrank and became more saline with displacive gypsum forming in older calcite deposits.

Other features such as wavy and planar lamina were documented but rare. One unit contained laminae which were defined by fibrous, organic material. A single mixed siliciclasticgypsum unit at $\sim 72 \mathrm{ft}(21.9 \mathrm{~m})$ with up to $40 \%$ siliciclastic minerals is interpreted as evidence for increased surface water inputs and a lacustrine period. XRD data taken from a mudstone unit at $59 \mathrm{ft}(18.0 \mathrm{~m})$ revealed 53\% magnesite and 19\% gypsum. A radiocarbon date from $34.3 \mathrm{ft}(10.5$ m) returned a calibrated age of $22 \mathrm{ka}$. Thin section petrography revealed some units with a mixed history of mud deposition, siliciclastic silt transport, and displacive gypsum.

A mix of lithologies including carbonate mudstones, gypsum mudstones, gypsum sandstones and siltstones, and mixed siliciclastic-gypsum sandstones and siltstones provide evidence for a variety of depositional environments. Aquatic fossils in the carbonate mudstones 
are interpreted as evidence for perennial brackish to saline lake deposition. The abundance of displacive gypsum, both in original position and very lightly reworked, suggests that saline mudflats were common and fine-grained sediment was removed. More heavily reworked gypsum sands and silts provide evidence of drier conditions and eolian processes that transported gypsum grains across the basin floor. The variety of lithologies and sedimentary structures indicate that wetting and drying was common and that perennial brackish to saline lakes persisted at times.

\section{Discussion}

\section{How to Define White Sands Deposits}

White Sands Cenozoic history has been poorly defined and lacks consistent terminology to describe deposits. The variety of environments interpreted within the core highlights the need for a framework that may help future geologists further study the Tularosa Basin and create a more coherent terminology amongst them.

Lithologies found in the core have been divided into 4 types of depositional environments, from least to most arid, perennial freshwater lacustrine, perennial brackish to saline lakes, perennial saline lake or lakes, and an eolian stage consisting of ephemeral lakes, saline mudflats, and sandflats. Figure 14 provides schematic illustrations of how these lakes may have occupied the basin floor. Depositional environments are difficult to spatially define based on a single core but defining environments based on sedimentological characteristics allows for a better understanding of White Sands history and will create a framework for other geologists to work within at White Sands. Figure 15 shows depositional stages relative to deposits found within the core. 
Perennial freshwater lake deposition was interpreted from laminated siliciclastic mudstones found from depths of 128 - $121 \mathrm{ft}(39.0$ - $36.9 \mathrm{~m})$. The paucity of gypsum and carbonates further suggests a freshwater environment. A perennial freshwater lake would likely have occupied a greater area of the basin floor then brackish or saline lakes (Fig. 14A). Siliciclastic sandstones and siltstones would be deposited during wetter periods where streams entered the lake, though are not found in the core. Although eolian processes could occur along the margins of the perennial freshwater lake, these deposits would likely be minimal due to the amount of surface inundated by water and stabilized by vegetation. Eolian deposits would not be found at the location where the core was drilled. If other cores were drilled in the White Sands area, perennial freshwater lake deposits would likely be an important marker bed when trying to laterally correlate, especially without ages. Perennial freshwater lakes would only exist during the wettest periods in the Tularosa Basin, times when precipitation was much greater than evaporation.

Perennial brackish to saline lakes would form during times when precipitation and evaporation were approximately equivalent (Fig. 14B). The most obvious evidence comes from the ostracods and charophytes found in a calcium carbonate mudstone from a depth of $83 \mathrm{ft}$ ( 25.3 $\mathrm{m})$ in the core. There is a possibility that some of the calcite found shallower than $83 \mathrm{ft}(25.3 \mathrm{~m})$ was also precipitated during a perennial brackish to saline lake stage, displacive gypsum has destroyed sedimentary structures. Other evidence for perennial brackish to moderately saline lakes in the core includes mudstones, which only mildly effervesced with $\mathrm{HCl}$, suggesting a mixed gypsum and calcite composition. Evapoconcentration would lead to precipitation of calcite and gypsum but lakes would be perennial. Siliciclastics would also be transported in by 
surface waters but would be restricted near their source and would be outpaced by gypsum and calcite production.

The saline lake or lakes stage would occur when there was enough water to maintain a lake or lakes most of the time, but evapoconcentration of waters would lead to saline conditions (Fig. 14C). Bottom-growth gypsum found in the core is evidence for saline lakes. This stage could take the form as one large lake, or several lakes filling local topographic lows on the basin floor. Evaporation would be greater than precipitation which would lead to evapoconcentration and precipitation of gypsum. Displacive gypsum would grow in the saline mudflats surrounding the lake. These lakes would possibly go completely dry at times and displacive gypsum may grow across the entire basin floor during desiccation. The saline lake(s) would regularly fluctuate in size which would allow for deflation of gypsum left exposed. Sand deposits containing lightly reworked, coarse crystal shapes can be used to interpret nearby saline lakes, especially if bottomgrowth gypsum can be recognized. Eolian sands related to the saline lake stage would likely be angular to almost intact crystals and coarse because gypsum crystal sources would be available across much of the basin floor. For perennial saline lakes to exist, there likely would have been a perennial input of waters but evaporation would be greater than inputs.

The ephemeral lake and eolian stage, would occur during the driest periods (Fig. 14D) and would consist of sandflat and saline mudflat deposits and possibly some bottom-growth gypsum. In this stage, abundant gypsum from older deposits would be available for eolian reworking and deposition in sandflats. Gypsum sands would be deposited over most of the basin floor and dunes would likely form. Abundant blocky, fine gypsum sands would be deposited during the eolian stage as gypsum would be transported greater distances. Ephemeral saline lakes would exist but typically would be dry, like modern Lake Lucero. Ephemeral gypsum crusts 
would form at the surface of these lakes after desiccation and it is likely that displacive gypsum would grow beneath the surface. Complete desiccation at the surface would lead to large quantities of older deposits to be deflated. The eolian stage occurs when evaporation is much greater than precipitation. No perennial streams would flow into the basin and flooding of the surface would be restricted to ephemeral streams and sheet floods. Sediments deposited by floodwaters would quickly desiccate.

\section{Lake Otero: A Longer History Than Previously Described}

Lake Otero, in some regards, has become geologic folklore, poorly defined due to limited study. Lake Otero has been loosely defined as the latest Pleistocene Lake in the Tularosa Basin (Allen, 2005). Spatially, Lake Otero has been defined by gypsum deposits of the Tularosa basin (Herrick, 1904; Meinzer and Hare, 1915; Kottlowski, 1958; Seager, 1987; Hawley, 1993; Allen, 2009).

Allen (2009) provides the only sedimentologic descriptions of sediment thought to be deposited from Lake Otero. These outcrops run along the western and northwestern margins of White Sands, where they rise 5 - $30 \mathrm{ft}$ (1.5 - 9.1 m) above the floor of Alkali Flat and Lake Lucero. The outcrops mark the boundary between alluvial fans from the San Andres Mountains and Lake Lucero and Alkali Flat. The outcrops have been labeled as shorelines or erosional shorelines (Langford, 2002). Others have suggested that the steep dips are the result of faulting (Kottlowski, 1958). Allen (2009) and Bustos (2018) describe the outcrops as being composed of interbedded and interlaminated gypsum muds and sands, siliciclastic muds, sands, and boulders, and calcite mudstones. Radiocarbon dates from the outcrops range from 10 - 40 ka. Radiocarbon dates of 12 - 16 ka present have been obtained from the nearby floor of Alkali Flat. Aquatic 
fossils have been found in these outcrops including ostracods (Candona, eucypris, Limnocythere, Cyprideis), mollusks (Stagnicolla, Planorbella, Physa), and a fish scale. Pleistocene megafauna footprints have been documented including giant ground sloths and mammoth in the outcrops and on the floor of Alkali Flat adjacent to the outcrops (Allen, 2009; Bustos et al., 2018). Allen (2009) interpreted gypsum crystals found in the outcrops as evidence for saline waters. Gypsum sands, erosional surfaces, and megafauna footprints were interpreted as evidence for subaerial exposure, and a more arid climate. Aquatic fossils were interpreted as evidence for Lake Otero. Increased siliciclastic content was interpreted as evidence for increased pluvial and fluvial processes and increased rainfall (Allen, 2009). Saline mudflats and sandflats were interpreted by Benison (personal communication) based on two large format thin sections taken from the outcrops.

There is evidence found in the core supporting Lake Otero as previously described such as ostracods and charophytes. Figure 16 shows the approximate correspondence of the radiocarbon date from the core to dates from the western outcrop. In the core, aquatic fossils were found $50 \mathrm{ft}(15.2 \mathrm{~m})$ below radiocarbon date from the core for approximately $22 \mathrm{ka}$, suggesting that Lake Otero may have existed further back in time than documented in the western outcrops. There was limited other evidence supporting lacustrine deposition in the upper $80 \mathrm{ft}(24.4 \mathrm{~m})$ of core. Several mixed siliciclastic-gypsum sandstones and siltstones are interpreted to have been deposited in wetter periods which would transport in the siliciclastic minerals. A single foraminifer was found at a depth of $44.3 \mathrm{ft}(13.5 \mathrm{~m})$ within a gypsum sandstone and siltstone composed almost entirely of gypsum interpreted as displacive in origin. The amount of displacive gypsum, even lightly reworked gypsum, suggests the basin conditions were wetter than modern. The lightly reworked nature of much displacive gypsum in the upper 
$80 \mathrm{ft}(24.4 \mathrm{~m})$ indicates that large quantities of sediment which gypsum precipitated in was deflated. The single foraminifer may have been blown in, but it is also a possibility that it is evidence of lacustrine sedimentation that was mostly deflated. There is little evidence for lacustrine deposition at the location of the core during the same time as lacustrine deposits formed on the western side. Saline Mudflats are commonly associated with saline lakes (Hardie et. al, 1972). The abundance of gypsum displacive in origin found in the upper part of the core suggests a history of saline groundwaters, likely in a saline mudflat which suggests saline lakes may have existed nearby but not been preserved in the core.

Deposits in the upper $80 \mathrm{ft}(24.4 \mathrm{~m})$ suggest the core was drilled in a location that may have been on the periphery of a perennial brackish to saline lake, occasionally inundated by water, but more often a saline mudflat or sandflat, that was frequently exposed to eolian processes. Displacive gypsum, muds containing siliciclastic sediment, and mud clumps contained within the same unit indicate that conditions frequently fluctuated which would be the case in a saline mudflat environment. Displacive gypsum would precipitate from saline groundwaters. Muds may be precipitated or reworked from elsewhere during flooding. Siliciclastic mineral grains may have been transported in either by wind or during sheet flood events.

XRD data revealed 52\% magnesite, 19\% gypsum, with the rest of the sediment being composed of predominantly siliciclastic minerals. Magnesite found in the Estancia Basin, a similar gypsum producing basin 43 miles $(70 \mathrm{~km})$ north of White Sands, was interpreted as evidence for desiccation of a Pleistocene lake there (Allen and Anderson, 2003). A similar interpretation is drawn for magnesite found in the White Sands core. Sandflat deposits overlain the magnesite-containing unit, evidence that the surface was completely desiccated allowing 
gypsum to be reworked. Further XRD analysis of the core may be worthwhile to document other magnesite layers if they exist. If more cores were drilled at White Sands, magnesite layers could be useful in correlating deposits.

Another possibility for deposits of the upper $80 \mathrm{ft}(24.4 \mathrm{~m})$ of core is that the lenticular gypsum is displacive gypsum in original depositional position. If this were the case, the calcite interpreted as cement would be the original sediment which displacive gypsum precipitated within and that original sedimentary structures were destroyed. The calcite would've precipitated from Lake Otero. The nearly perfect lenticular crystal shapes found in many units could be used as evidence to support this. The foraminifer found at $44.3 \mathrm{ft}(13.5 \mathrm{~m})$ also helps support this hypothesis. There is contradictory evidence that supports that the displacive gypsum is lightly reworked and that the calcite is cement, not the original host sediment. Obvious displacive gypsum found at other depths in the core was randomly oriented and always separated by the sediment within which it precipitated, characteristics of displacive gypsum. Many of the displacive gypsum crystals found in the upper $80 \mathrm{ft}(24.4 \mathrm{~m})$ were in contact with each other and aligned which suggests that sediment supporting it was deflated allowing the displacive gypsum grains to settle.

While the abundance of gypsum and calcite are interpreted as evidence that Lake Otero was saline or saline at times, the laminated siliciclastic mudstones found between $\sim 128-121 \mathrm{ft}$ (39.0 - $36.9 \mathrm{~m})$ suggest Lake Otero was fresh for some period, though the age of these deposits is unknown. The laminated siliciclastic mudstones exhibited a coarsening upward sequence into mixed siliciclastic-gypsum sandstones and siltstones. The mixed nature of siltstones is interpreted as the result of reworking of older gypsum deposits mixed with siliciclastic minerals transported in during the perennial freshwater lake stage. The abundance of gypsum below the 
perennial freshwater lake deposits suggest that gypsum deposits likely covered a large part of the basin floor and would be available for erosion once the lake size reduced.

Siliciclastics containing freshwater aquatic fossils have been found stratigraphically above gypsum deposits in the Tularosa Basin and informally named the Tularosa formation (Lucas, 2002). No gypsum lies above these units and they were thought to be younger than Lake Otero deposits (Lucas, 2002). It is possible that "Tularosa formation" deposits are related to the perennial freshwater lake deposits found at from $\sim 128$ - $121 \mathrm{ft}(39.0$ - $36.9 \mathrm{~m})$ in the core, especially considering no other evidence for freshwater deposition was found above the laminated siliciclastic mudstones in the core. The gypsum deposits below the "Tularosa Formation" would correlate to the gypsum deposits below the laminated siliciclastic mudstones.

\section{The Role of Hydrology at White Sands}

This study isn't focused on hydrology of the Tularosa Basin, but it does provide some data which helps understand the role of hydrology in White Sands past. While it may seem contradictory in a desert environment, hydrology has played a key role in the development of White Sands. Solutes have been transported into the system from the surrounding mountain ranges and below the basin floor by fluvial, alluvial, and groundwater processes. Freshwater can dissolve gypsum and recycle it in the system while saline waters precipitate gypsum. A high groundwater table and surface waters would have helped protect sediment from deflation. The

abundance of displacive gypsum highlights the role of saline groundwaters in gypsum production at White Sands. Desiccation of the surface would allow for reactivation of surfaces through eolian processes which leads to reworking of older deposits. 
The large clastic gypsum deposits highlight the delicate climate balance, enough water to carry solutes into the system, dry enough that gypsum is not dissolved. The perennial freshwater lake deposits suggest that, at times, it has been wet enough in White Sands geologic history to completely shut off gypsum production. Other researchers have proposed that a decrease in the elevation of the water table has left gypsum exposed and available to be deflated into the modern dune field (Langford, 2002; Ewing and Kocurek, 2010). The amount of reworked displacive gypsum found in the core supports this hypothesis and suggests that fluctuations in the water table have been common in the past at White Sands, with displacive gypsum precipitating just below the surface from saline groundwaters and previous deposits being carved away by wind once the water table no longer was able to help stabilize the sediment.

\section{Source of the Dune Sand}

The abundance of lenticular gypsum grains, both interpreted as in-situ displacive gypsum and reworked clastic gypsum, in the core show that saline groundwaters have been very important in producing gypsum that forms the modern-day dune field and deposits below. The abundance of eolian material in the core also draws the question of how much sediment has been lost through deflation. Ewing and Kocurek (2010) and Allmendinger (1973) suggested that most modern gypsum sand input into the dune field comes from modern precipitation. Knapp et al. (2017) also suggested that bottom-growth gypsum precipitates during the greatest flood events in the modern and that this material is deflated to the dune field. While it does appear that some gypsum precipitates today, mostly restricted to efflorescent crusts and displacive gypsum, it is apparent that much greater quantities of gypsum were deposited in the past. If the abundance of displacive gypsum found in the core is common across the basin, it would suggest older 
displacive gypsum deposits are the main source of dune sand. It is also likely that bottom-growth gypsum from ancient lakes has been reworked into the dune field, but there was limited evidence for bottom-growth gypsum found in the core.

While it has been suggested that gypsum crystals up to $1 \mathrm{~m}$ in length, unique to the west side of White Sands, are the source of gypsum dunes, this study suggests the opposite, that more common displacive and bottom-growth gypsum reworked from the basin floor is the source to the modern-day dunes. The amount of displacive gypsum found in the core suggests there will be a large supply of gypsum to the dune field for the foreseeable future.

\section{Dating Lake Otero Deposits}

The radiocarbon date of $22 \mathrm{ka}$ from a depth of $35.3 \mathrm{ft}(10.8 \mathrm{~m})$ indicates the core preserves sediments that are likely older than anything described by previous authors. The laminated siliciclastic mudstones found from 128 - $121 \mathrm{ft}(39.0$ - $36.9 \mathrm{~m})$ provide evidence that Lake Otero was a large, perennial freshwater lake for some time. The paucity of gypsum and carbonate in these deposits suggest that this was an especially wet climatic period, where a nearly continuous source of freshwater was input into the Tularosa Basin. The radiocarbon date of $22 \mathrm{ka}$ from $35.3 \mathrm{ft}(10.7 \mathrm{~m})$ eliminates the possibility that these were deposited during the last glacial maximum 10 - $20 \mathrm{ka}$. I hypothesize that laminated siliciclastic mudstones were likely deposited approximately 130 - $160 \mathrm{ka}$, during the Bull Lake glaciation. Moraines found on Sierra Blanca have been hypothesized to have been related to alpine glaciation during the Bull Lake glacial period, which lasted from approximately 140 - 200 ka (Richmond, 1964). With glaciers occupying Sierra Blanca, it is likely that a large quantity of water would be provided by 
perennial streams. Laminae in the siliciclastic mudstones may be varves representing seasonal variations in deposition.

If my age hypothesis is correct for the laminated siliciclastic mudstones, gypsum deposits below the perennial freshwater deposits suggest evaporites have been deposited in Tularosa Basin for at least 150,000 years, likely more. It is possible that gypsum precipitation initiated after the Rio Grande River, which flowed just south of White Sands was diverted from Tularosa Basin, sometime during the Middle Pleistocene. Interestingly, older gypsum deposits are found in the Mesilla Basin, a basin west of White Sands separated by the San Andres Mountains, where the Rio Grande River now flows (Seager et al, 1987). Diverting a perennial river out of Tularosa Basin would have a great effect on the hydrologic conditions and may have led to initiation of gypsum production.

The laminations and coarsening upwards of mixed siliciclastic-gypsum sandstone and siltstone deposits near the base of the core were similar to the laminated siliciclastic mudstones and overlying mixed siliciclastic-gypsum sandstones which suggests that a perennial freshwater lake may have existed even further back in time. The deposits near the base are not as strongly laminated but do show a similar coarsening upwards sequence to those found at $121.7 \mathrm{ft}$ ( 37.1 m). It's also possible that the mixed siliciclastic-gypsum sandstones and siltstones near the base are related to the Camp Rice Formation, which would mean the core drilled completely through deposits related to Lake Otero. More cores drilled to greater depths would be needed to confirm whether this core penetrated entirely through Lake Otero and associated deposits. 


\section{Comparison with other southwest USA Pleistocene lakes}

Comparing White Sands to other southwestern lakes is somewhat of a challenge given the uniqueness of its gypsum nature. There is evidence that many western USA lakes fluctuated in area, depth, and salinities in the last $45 \mathrm{ka}$. Benson et al. (2011) interpreted that Lake Bonneville, frequently fluctuated in depths throughout the last 45,000 years and climate was the main driver of lake level fluctuations. Western lakes including Lake Bonneville (Benson et al., 2011) and Lake Lahontan (Benson et. al 1987) reached high stands 10 - 20 ka. Evidence found in the White Sands core does not support that Lake Otero reached a high stand during that same time. Instead Lake Otero likely reached a high stand earlier in the Pleistocene when the laminated siliciclastic mudstones were deposited.

A core study from Death Valley by Lowenstein et. al. (1999) provides a detailed record of evaporite and lacustrine deposition throughout the last 200,000 years from a core. Both are in closed basins. Death Valley is dominated by halite while Tularosa Basin is dominated by gypsum. Both basins contain evaporites and siliciclastics. The sequence of events in Death Valley interpreted by Lowenstein et al. (1999) is similar to the sequence of events interpreted from White Sands. Figure 17 summarizes Lowenstein et al. (1999) description of Death Valley environments and compares with White Sands interpretations. Mudflats were more common in the Death Valley core than the White Sands core, but the grain shape of many sand deposits at White Sands support that mudflats likely existed simultaneously with sandflats and eolian environments. Halite at Death Valley is also not reworked into clastic material like gypsum from White Sands. Even at Modern White Sands, saline mudflats often contain eolian gypsum sand at the surface. Death Valley contained a large, perennial lake approximately 130 - $185 \mathrm{ka}$. Based on the depth of the deposits in the White Sands core and the Bull Lake glaciation of Sierra Blanca, 
the perennial freshwater lacustrine deposits from the White Sands core were interpreted to have been deposited roughly 130 - 160 ka which correlates well to Death Valley.

\section{Future Studies and Challenges Associated with Studying White Sands}

While this study offers new insights and a detailed sedimentologic history of White Sands, it has obvious limitations. The most obvious is that this core represents a single point in a the $\sim 400 \mathrm{mi}^{2}\left(650 \mathrm{~km}^{2}\right)$ White Sands area and $\sim 6,000 \mathrm{mi}^{2}\left(9656 \mathrm{~m}^{2}\right)$ Tularosa Basin. Given the high degree of variation in evaporite depositing environments, drawing conclusions about the entire White Sands area from a single point is challenging. While some things are clear, laminated siliciclastic mudstones indicate a perennial freshwater lake existed in the basin, bottom-growth gypsum indicates saline lakes, displacive gypsum indicates saline groundwaters, it is nearly impossible to conclude the areal extent of these environments. A perennial freshwater lake likely would occupy more area in the basin than saline lakes, but it is unknown how basin topography has varied over time and with this how deposits have shifted. Ultimately to gain a more complete understanding of the Tularosa Basin more cores need to be drilled to provide greater spatial details. Suggestions for location of further drilling would include the northwestern margin, Lake Lucero, just northeast of the dunes and to the southeast of the dune field. It is recommended that cores be drilled deeper than a hundred $\mathrm{ft}(30.5 \mathrm{~m})$, preferably $300 \mathrm{ft}(91.4 \mathrm{~m})$ or more to hopefully capture the base of evaporite deposits related to Pleistocene sedimentation.

This study was focused on the detailed sedimentology of the core, something necessary before undertaking other studies of the core. More chemical and thin section data would help gain better understanding of White Sands sedimentologic history. XRD focused on identifying the composition of the mudstone units would be especially useful. Further thin section 
petrography may reveal more fossils, which could further help determine the history of White Sands. Fluid inclusion analysis of gypsum grains may allow for the determination of past water chemistry.

Given the unique nature of White Sands, it seems that it would be a place that has been studied in detail. In reality, except for the dunes, there is little information regarding White Sands geologic history. White Sands Missile Range and Holloman Air Force Base occupy most of White Sands limiting public access. Most studies regarding the dune field have been performed at White Sands National Monument, which highlights the importance of public lands. Even then, scientists must go through a permitting process and unless there is direct cooperation with the National Park Service, it is extremely difficult to access Alkali Flat and Lake Lucero as access is restricted to either missile range roads, a 6.8 -mile $(11 \mathrm{~km})$ hike, or by National Park Service operated off-road vehicles.

\section{Conclusions}

Abundant eolian sands are evidence of a long history of eolian processes at White Sands. Perennial freshwater, perennial brackish to saline, and saline lake deposits recorded in the core help understand the history of Lake Otero, a history that has been poorly defined before this study. Lake Otero has changed in size and salinity throughout the Middle to Late Pleistocene. Sedimentological deposits provide evidence for saline lake deposition, perennial brackish to saline lake deposition, perennial freshwater lake deposition, and eolian deposition. Abundant displacive gypsum found in the core highlights the importance of saline groundwaters in shaping modern day White Sands geology. Laminated, siliciclastic mudstones found in the core provide the first concrete evidence for a perennial freshwater lake and humid climate in the Tularosa 
Basin. If these deposits are related to the Bull Lake glaciation, it would suggest that the core has recorded a geologic history for at least 150,000 years, likely more.

This study highlights the importance of detailed sedimentologic studies at White Sands. By detailing crystal morphologies, it was possible to distinguish depositional environments of White Sands in the past. More work must be performed to unravel the complex geologic history of White Sands. 


\section{References}

Allen, D.B. and Anderson, R.Y., 2000, A continuous, high-resolution record of late Pleistocene climate variability from the Estancia basin, New Mexico: GSA Bulletin, v. 112, is. 9, p. 14441458.

Allen, B.D., 2005, Ice Age lakes in New Mexico: New Mexico Museum of Natural History and Science Bulletin, no. 28, p. 107-114.

Allen, B.D., 2009, Evidence for late Pleistocene hydrologic and climatic change from Lake Otero, Tularosa Basin, south-central New Mexico, New Mexico Geology, v. 31, issue 1, p. 9-25.

Allmendinger, R.J., 1971, Hydrologic control over the origin of gypsum at Lake Lucero, White Sands National Monument, New Mexico (Master's Thesis): New Mexico Institute of Mining and Technology, Socorro, NM, United States, 182 p.

Allmendinger, R.J. and Titus, F.B., 1973, Regional hydrology and evaporative discharge as present-day source of Gypsum at White Sands National Monument, New Mexico: New Mexico Bureau of Geology and Mineral Resources, Open-File Report 55., 45 p.

Benison, K.C., Bowen, B., Oboh-Ikuenobe F. E., Jagniecki, E. A., LaClair, D.A., Story, S.L, Mormile, M., and Hong, B., 2007, Sedimentology of acid saline lakes in southern Western Australia: newly described processes and products of an extreme environment: Journal of Sedimentary Research, v. 77, p. 366-388.

Benison, K.C., 2019, Physical and chemical sedimentology of two high-altitude acid salars in Chile: sedimentary processes in an extreme environment: Journal of Sedimentary Research, V 89, p. $147-167$.

Benson, L.V., and Thompson, R.S., 1987, Lake-level variation in the Lahontan Basin for the past 50,000 Years: Quaternary Research: v. 28, no. 1, p. 69-85.

Benson, L.V., Lund, S. P, Smoot, J. P., Rhode, D. E., Spencer, R. J., Verosub, K.L., Louderback, L. A., Johnson, C. A., Rye, R. O., and Negrini, R. M., 2011, The rise and fall of Lake Bonneville between 45 and 10.5 ka: Quaternary International, v. 235, p. 57-69.

Bustos, D.B., Jakeway, J., Urban, T.M, Holliday, V.T., Fenerty, B., Raichlen, D.A., Budka, M., Reynolds, S.C., Allen, B.D., Love, D.W., McDonald, H.G., and Bennett, M.R., 2018, Footprints preserve terminal Pleistocene hunt? Human-sloth interactions in North America: Science Advances, v. 4, no. 4.

Dunbar, N., 1999, Cosmogenic ${ }^{36} \mathrm{Cl}$-determined age of the Carrizozo lava flows, south-central New Mexico: New Mexico Geology, v. 21, no. 1, p. 25-29 
Ewing, R.C., and Kocurek, G. A., 2010, Aeolian dune interactions and dune-field pattern formation: White Sands Dune Field, New Mexico: Sedimentology, v. 57, is. 5.

Hardie, L.A., Smoot, J.P., and Eugster, H. P., 1978, Saline lakes and their deposits: A sedimentological approach: Special Publications of International Association of Sedimentologists, v. 2, p. 7-41.

Hawley, J.W., 1993, Geomorphic setting and late quaternary history of pluvial-lake basin in the southern New Mexico region: New Mexico Bureau of Mines and Mineral Resources, Open-File Report 391. 28 p.

Herrick, C.L., 1904, Lake Otero, an ancient salt lake in southeastern New Mexico: The American Geologist, v. 34, pp. 174-189.

Jerolmack, D.J., Reitz, M. D., and Martin, R. L., 2011, Sorting out abrasion in a gypsum dune field: Journal of Geophysical Research, v. 116. 15 p.

Lowenstein, T.K., Brown, C., Roberts, S.M., Ku, T.L., Lao, S., and Yang, W., 1999, 200 k.y. paleoclimate record from Death Valley salt core: Geology, V. 27, no. 1, p. 3-6.

Lucas, S.G. and Hawley, J.W., 2002, The Otero Formation, Pleistocene lacustrine strata in the Tularosa Basin, southern New Mexico, New Mexico Geological Society $53^{\text {rd }}$ Annual Fall Field Conference Guidebook, p. 277-283.

Knapp, J.P., Benison, K.C., Dovick, M.A., and Bustos, D., 2016, A lacustrine model for White Sands National Monument, New Mexico: Abstracts with Program, Geological Society of America Annual Meeting, Denver, CO.

Kocurek, G., Carr, M., Ewing, R., Havholm, K.G., Nagar, Y.C., and Singhvi, A.K., 2007, White Sands dune field, New Mexico: Age, dune dynamics and recent accumulations: Sedimentology, v. 197, p. 313-331.

Kottlowski, F.E., 1958. Lake Otero: second phase in formation of New Mexico's gypsum dunes: Geological Society of American Bulletin 69, p.1733-1734.

Langford, R.P., 2003, The Holocene history of the White Sands dune field and influences on eolian deflation and playa lakes: Quaternary International, v. 104, p. 31-39.

Meinzer, O.E. and Hare, R.F., 1915, Geology and water resources of Tularosa basin, New Mexico: USGS Water Supply Paper, no 343. 
McKee E.D., 1966, Structures of dunes at White Sands National Monument, New Mexico (and a comparison with structures of dunes from other selected areas): Sedimentology, v. 7, i. 1, p. 369.

McKee, E.D. and Moiola, R.J., 1975, Geometry and growth for the White Sands Dune Field: New Mexico, Journal Research U.S. Geologic Survey, v. 3, no. 1, p. 59-66.

Newton, B.T. and Allen, B., 2014, Hydrologic investigation at White Sands National Monument: New Mexico Bureau of Geology and Mineral Resources, Open-File Report 559, 51 p.

Richmond, G.M., 1964, Glacial Deposits on Sierra Blanca, New Mexico Geologic Society $15^{\text {th }}$ Annual Fall Field Conference Guidebook, 195 p.

Seager, W.R., Hawley, J.W., Kottlowski, F.E., and Kelley, S.A., 1987, Geology of the east half of Las Cruces and northeast El Paso $1^{\circ}$ x $2^{\circ}$ sheets, New Mexico: New Mexico Bureau of Mines and Mineral Resources, Geologic Map 57, 5 sheets, scale 1:125,000.

Schmidt, P.G. and Craddock, C., 1964, The geology of the Jarilla Mountains, Otero County, New Mexico: New Mexico Bureau of Mines and Mineral Resources, Bulletin 82. 65 p.

Schreiber, B.C., El Tabakh, M., 2000, Deposition and early alteration of evaporites: Sedimentology, v. 47, p. 215-238.

Smoot, J.P. and Castens-Seidell, B., 1994, Sedimentary features produced by efflorescent salt crusts, Saline Valley and Death Valley, California: in Renaut, R., and Last, W., eds., Sedimentology and Geochemistry of Modern and Ancient Saline Lakes: SEPM, Special Publication 50, p. 73-90.

Soulié-Märsche, I. and Garcia, A., 2015, Gyrogonites and oospores, complementary viewpoints to improve the study of the charophytes: Aquatic Botany, v. 20, pt A, p 7-17.

Stanesco, J.D., 1991, Sedimentology and depositional environments of the Lower Permian Yeso Formation, northwestern New Mexico: USGS Survey Bulletin 1808-M. 11 p.

Stuart, C.J. and Willingham, D.L., 1984, Late Tertiary and Quaternary fluvial deposits in the Mesilla and Hueco bolsons, E1 Paso area, Texas: Sedimentary Geology, v. 38, p. 1-20. 


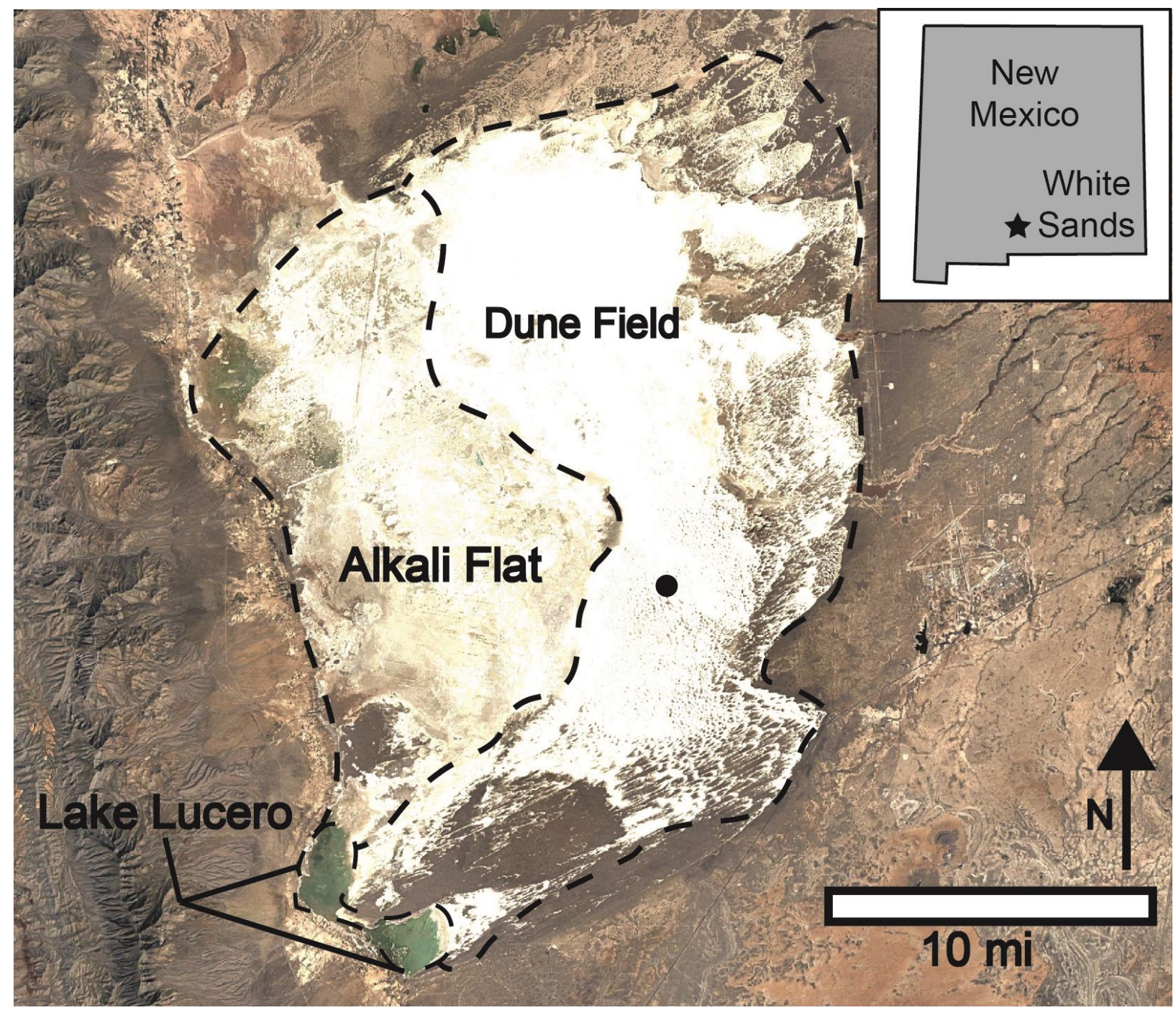

Figure 1. Map of White Sands with Lake Lucero, Alkali Flat, and the Dune Field outlined. Dot marks the location the core was drilled. Imagery was taken in 2007, note flooding on Lake Lucero's surface. Landsat/Copernicus imagery from Google Earth Pro. 3247’23.39” N, $106^{\circ} 19^{\prime} 11.86^{\prime \prime} \mathrm{W}$, Elevation $3937 \mathrm{ft}$ (1200 m) a.s.1.. 

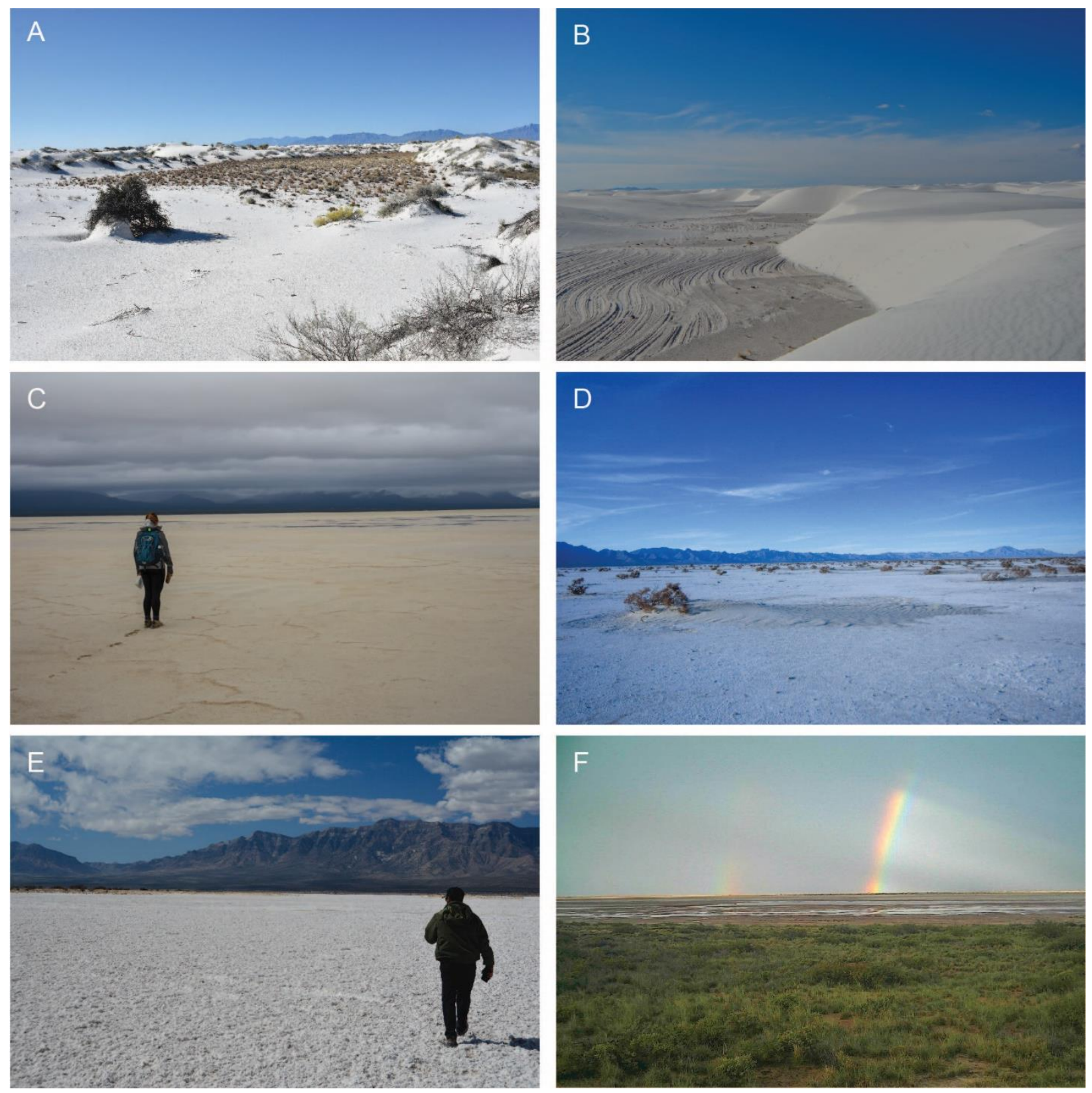

Figure 2. Modern environments at White Sands. A) Vegetated dunes and interdunes. B) Transition from dunes to Alkali Flat. C) Barren Alkali Flat with minor flooding. D) Vegetated area of Alkali Flat with a minor efflorescent crust. E) Looking west across Lake Lucero, efflorescent crust on the surface of Lake Lucero. F) Looking east across Lake Lucero, minor surface flooding following a rainstorm. 


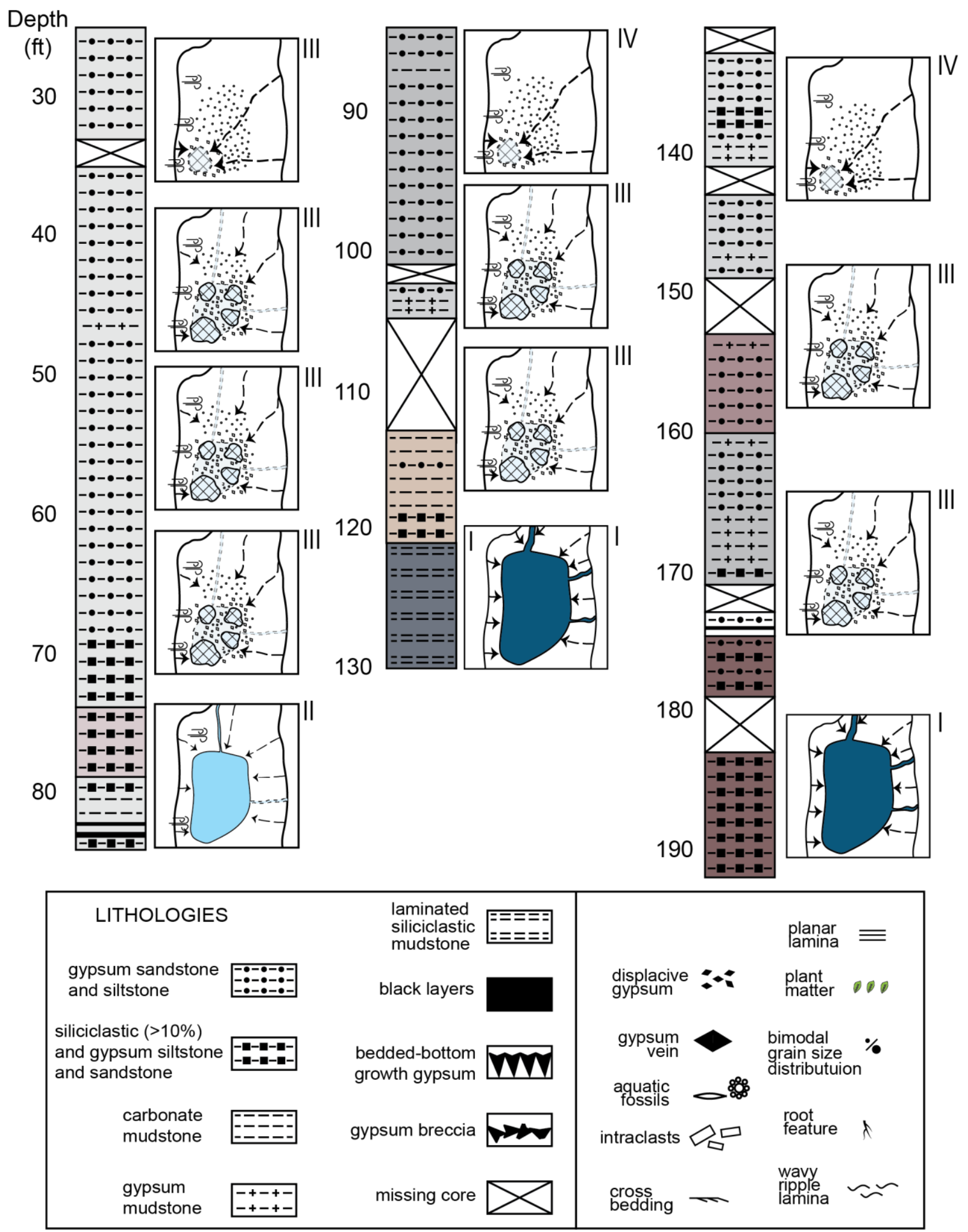

Figure 3. Simplified stratigraphic column of White Sands Core, MW-12-11. Color represents color of core. 


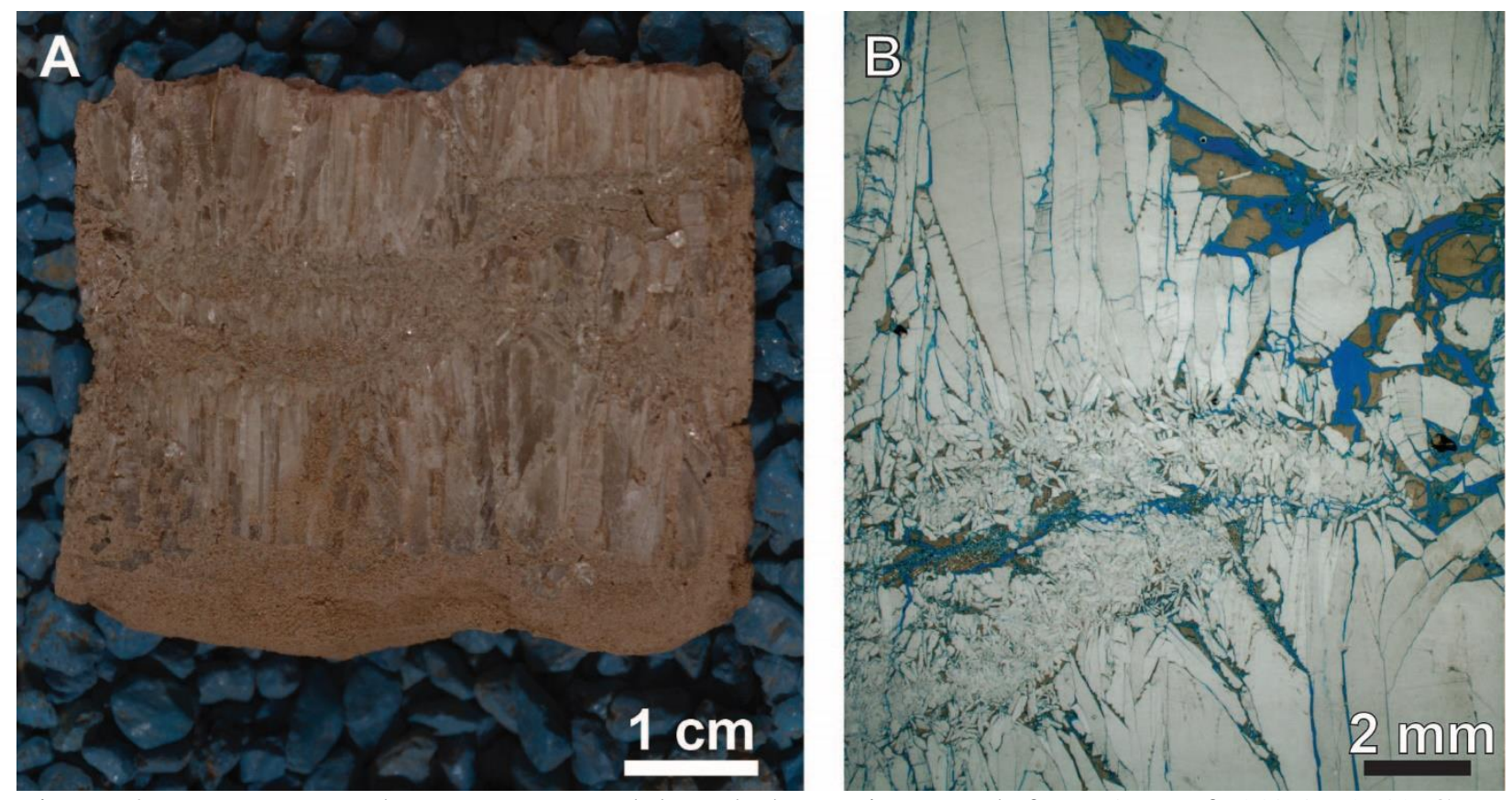

Figure 4. Bottom-growth gypsum core slab and photomicrograph from $167.7 \mathrm{ft}(51.1 \mathrm{~m}) \mathrm{A}$ ) Core slab with several bottom-growth beds. B). Bottom-growth gypsum separated by gypsum sands. 

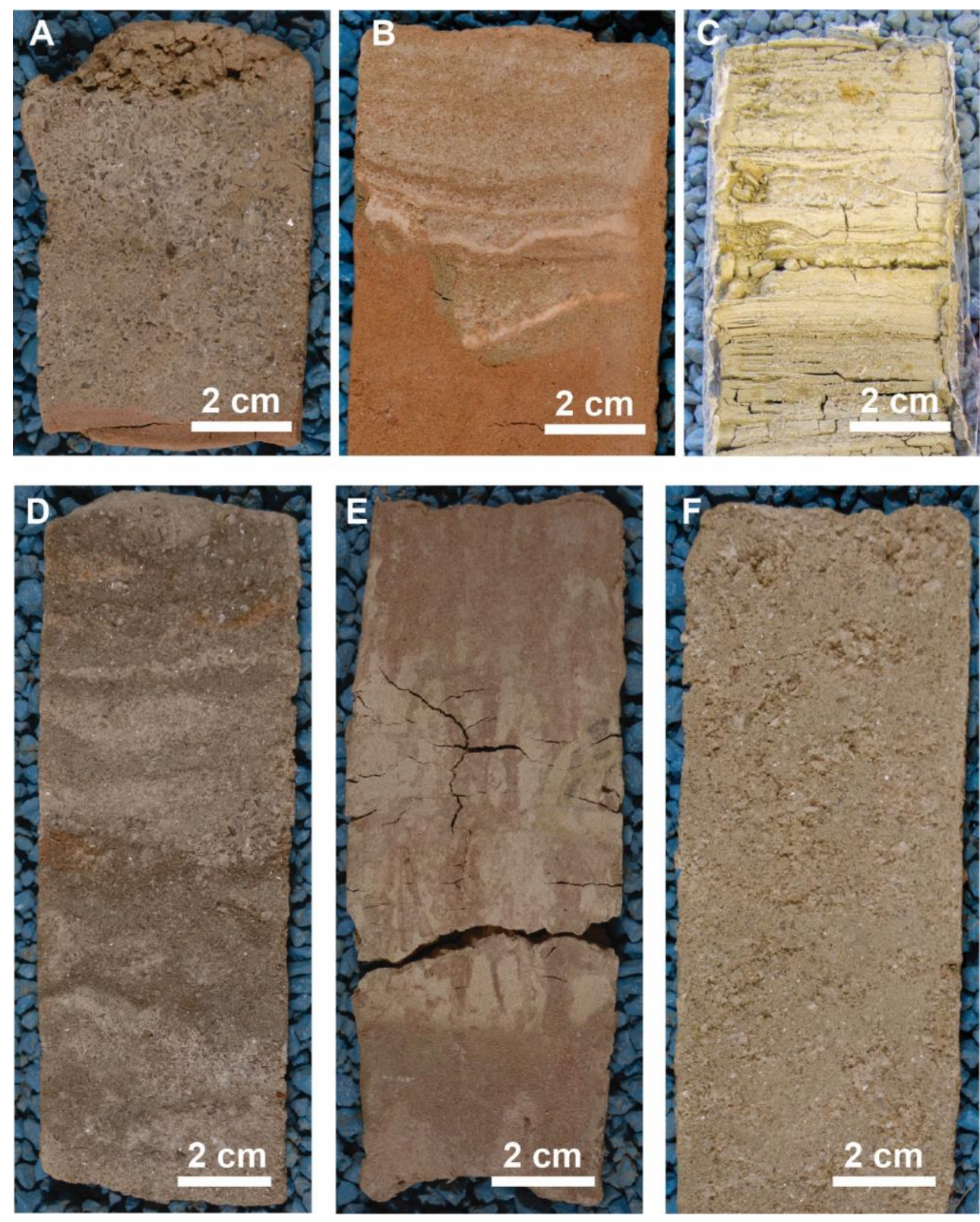

Figure 5. Gypsum

sandstone and siltstone core slab photos. A) $178.1 \mathrm{ft}$ (54.3 m). First pure gypsum sandstone found in the core. B) 103.0. $\mathrm{ft}(31.4 \mathrm{~m})$.

Laminated, coarse gypsum sandstone above a mixed siliciclasticgypsum siltstone. C) $130.0 \mathrm{ft}(39.6$ m). Bedded, coarse gypsum sandstone. D) $148.0 \mathrm{ft}$. (45.1 m) Poorly cemented, laminated gypsum siltstone. E) 140.2 $\mathrm{ft}$ (42.7 m).

Gypsum sandstone with vertical root features. F) $93.0 \mathrm{ft}$ (28.3 m). Porous, poorly sorted gypsum sandstone. 

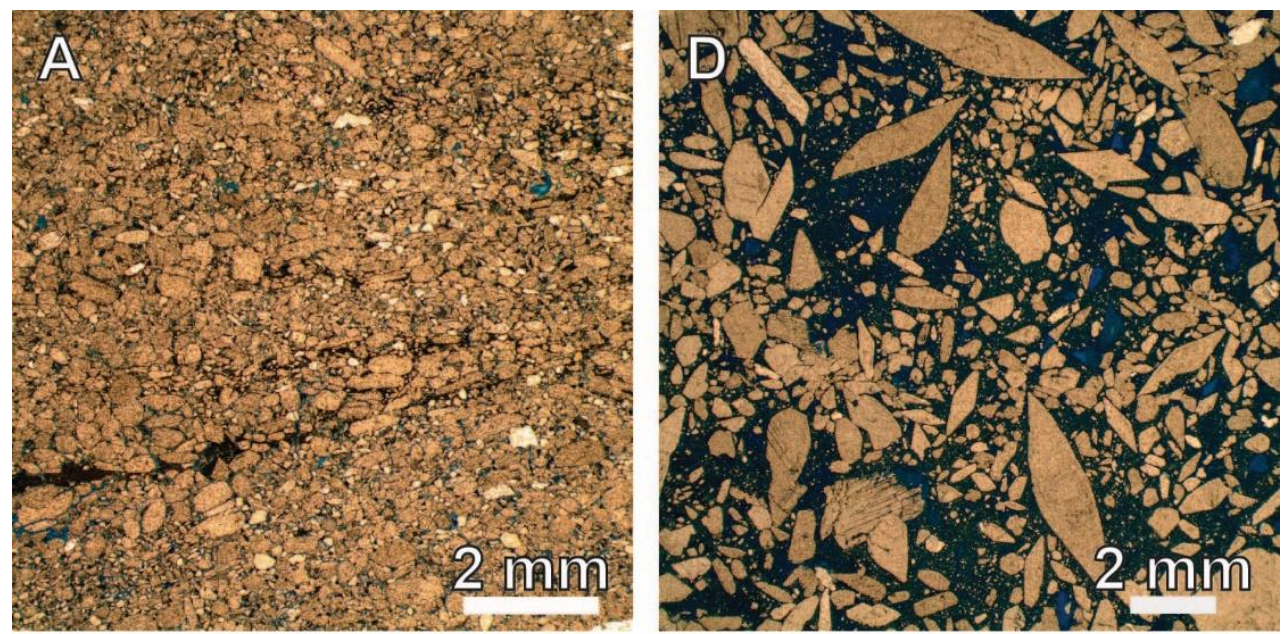

Figure 6. Gypsum

sandstones and

siltstone

photomicrographs

showing different

grain shapes. A)

$93.2 \mathrm{ft}(28.4 \mathrm{~m})$.

Blocky gypsum

sands B) $178.1 \mathrm{ft}$

(54.3 m). Sharp

contact between,

gypsum silt at base
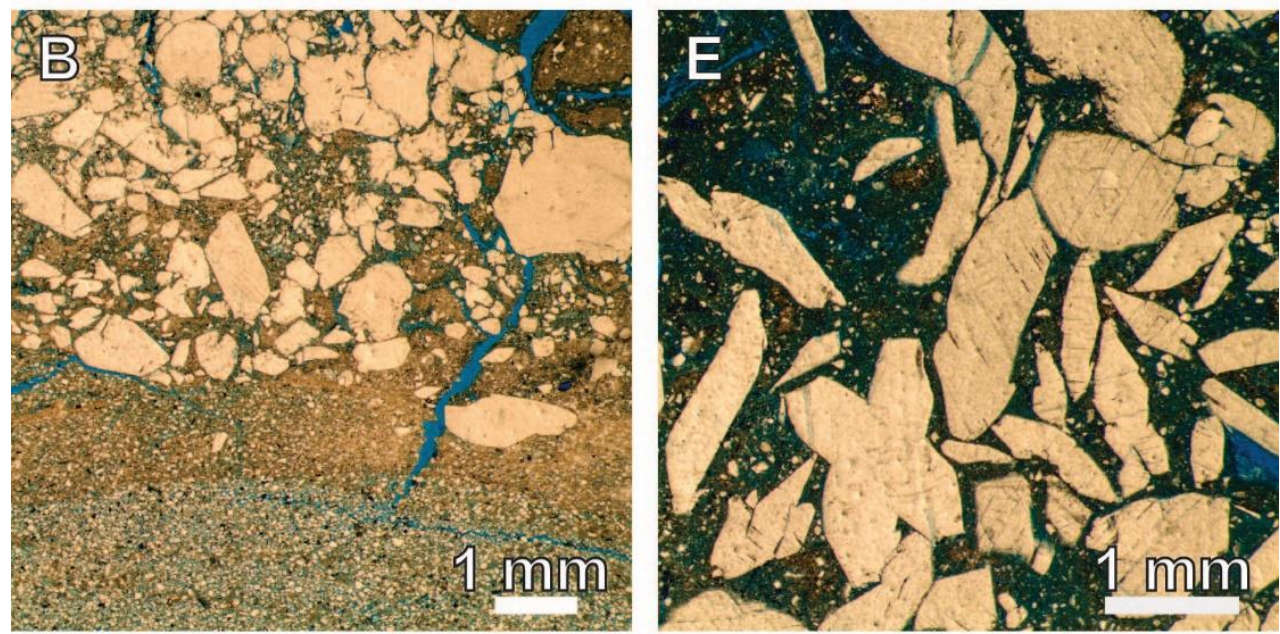

and coarse gypsum sand. C) $134.9 \mathrm{ft}$

(41.1 m).

Subrounded to angular gypsum sands. D) $129.6 \mathrm{ft}$ (39.5 m). Bimodal distribution of angular to almost perfect crystal shape gypsum grains. E) $157.8 \mathrm{ft}$ (48.1 m). Lightly
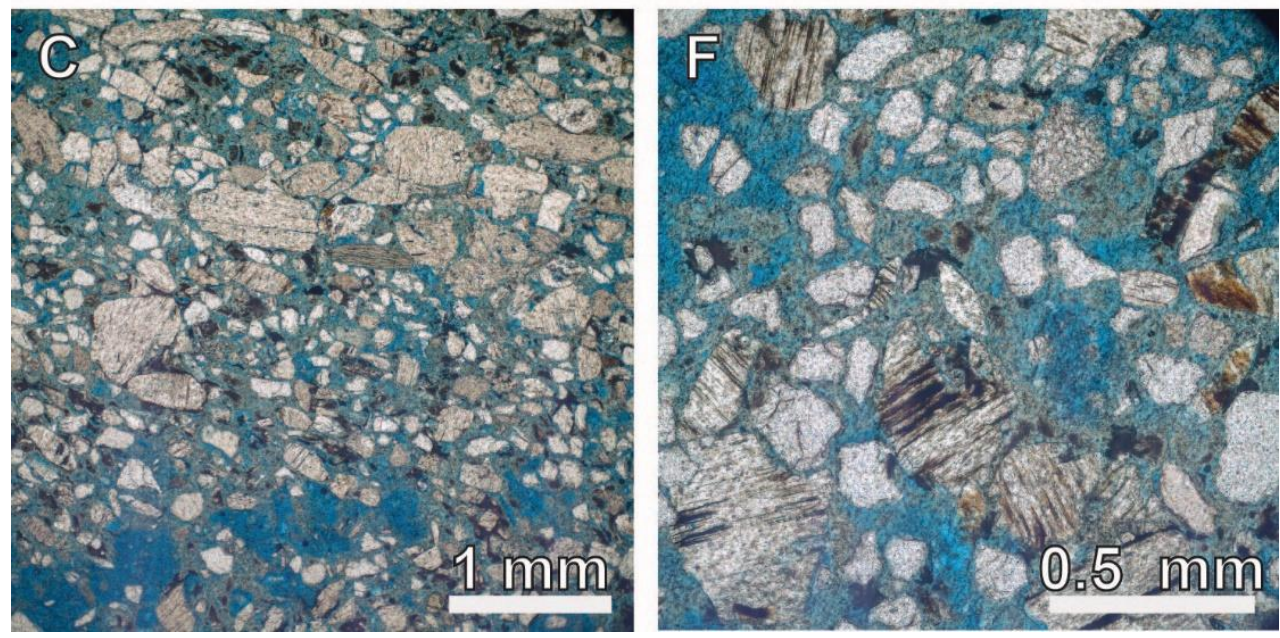
reworked, coarse gypsum sands F) $134.9 \mathrm{ft}$ (41.1 m). Parallel bands on gypsum surface interpreted as mud trapped within growth bands. 

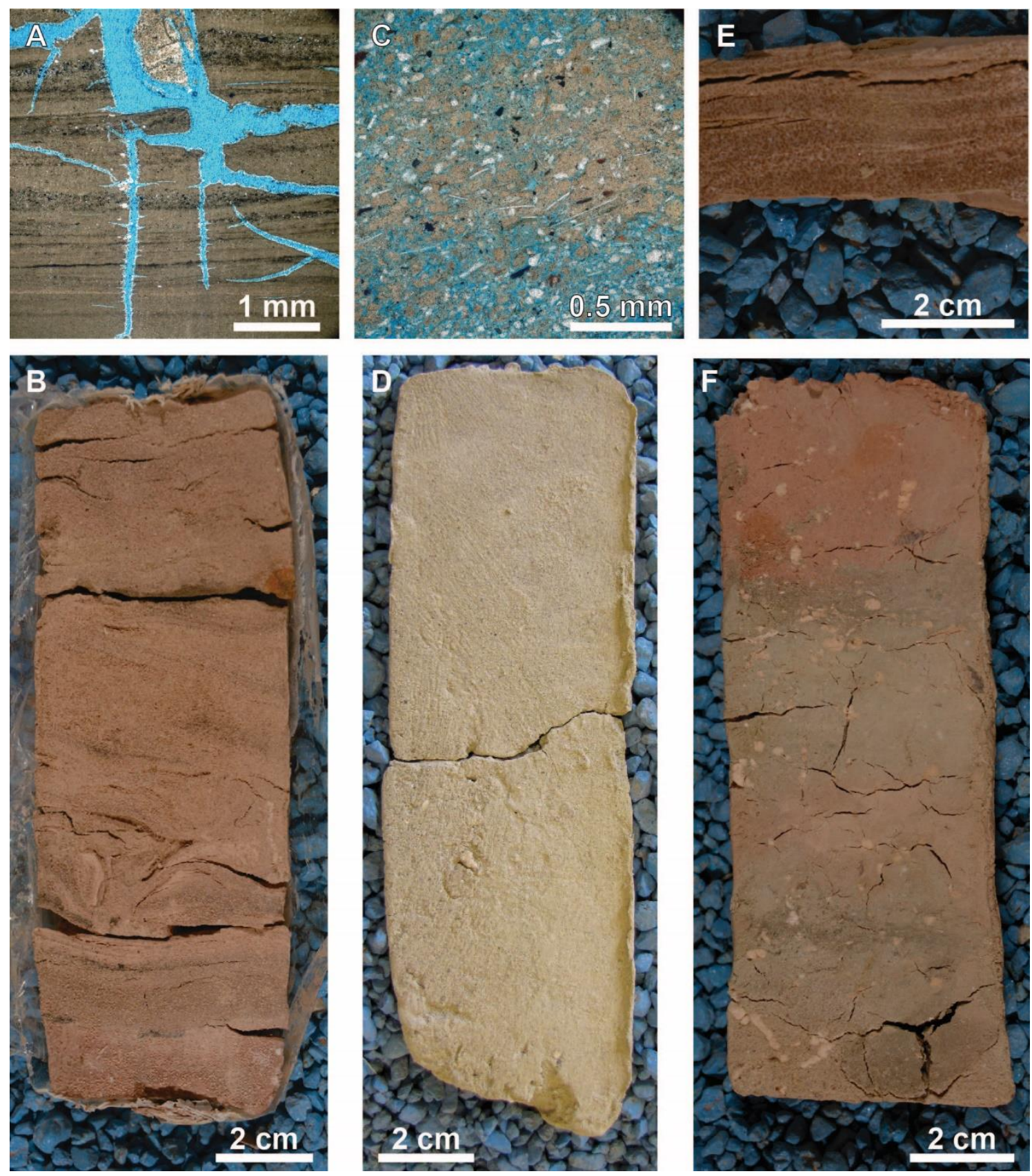

Figure 7. Core slab photos and photomicrographs of mixed siliciclastic - gypsum sandstones and siltstones. A) $190.7 \mathrm{ft}(58.1 \mathrm{~m})$. Photomicrograph of root features and lamina in a siliciclastic pure siltstone. B) $119.6 \mathrm{ft}(36.5 \mathrm{~m})$. Dewatering structure near base of slab with cross lamina above. C) $186.7 \mathrm{ft}(56.9 \mathrm{~m})$. Organic fragments in a mixed siliciclastic - gypsum siltstone with some mud lamina. D) $72.3 \mathrm{ft}(22.0 \mathrm{~m})$. Massive mixed siliciclastic-gypsum sandstone with $\sim 40 \%$ siliciclastics. E) $175.3 \mathrm{ft}$ (53.4 m). Core slab showing wavy lamina. F) $76.7 \mathrm{ft}$ (23.4 m). Mixed siliciclastic - gypsum siltstone containing carbonate nodules. Some have a gastropod shape. 

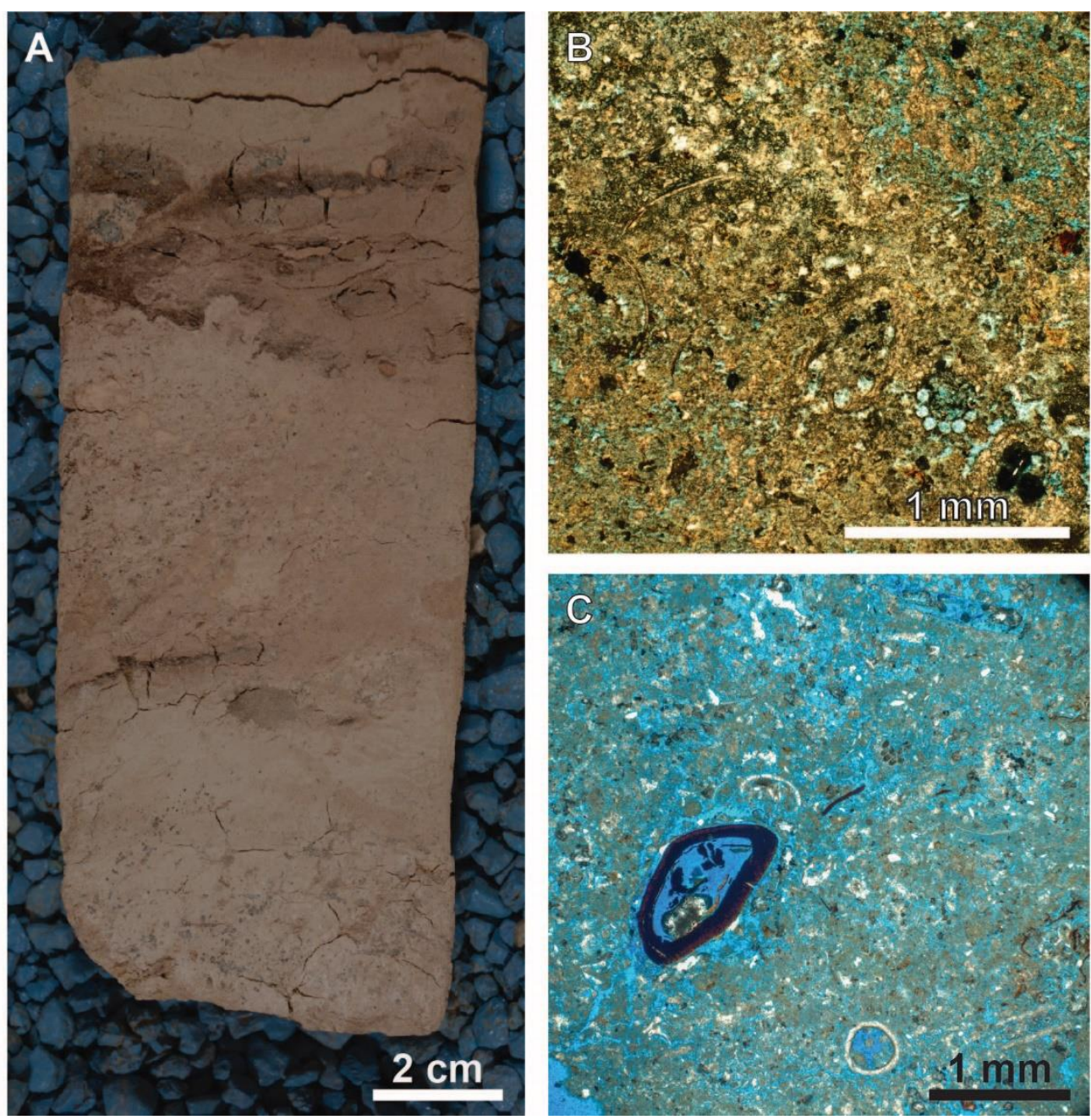

Figure 8. Thin sections and core slab photos of carbonate mudstones. A) Carbonate mudstone from $83.6 \mathrm{ft}(25.5 \mathrm{~m})$. B) $83.6 \mathrm{ft}(25.5 \mathrm{~m})$. Thin section highlighting multiple ostracod and charophyte valves. C) $83.6 \mathrm{ft}(25.5 \mathrm{~m})$. ostracods, charophytes, and a seed. 

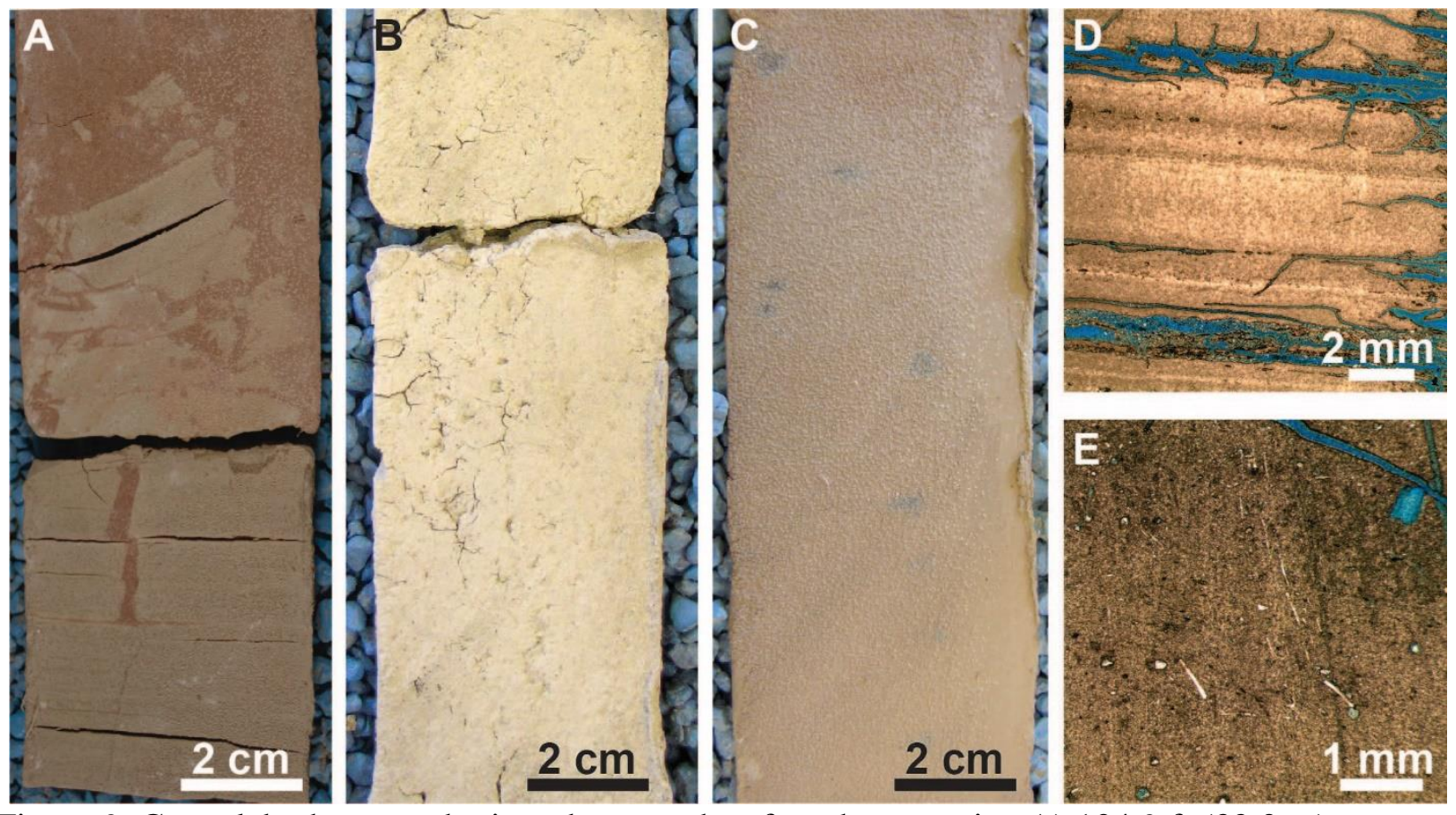

Figure 9. Core slab photos and microphotographs of mudstone units. A) $104.9 \mathrm{ft}(32.0 \mathrm{~m})$. Laminated gypsum mudstone forming intraclasts in the mixed siliciclastic-gypsum siltstone above. B) $88.0 \mathrm{ft}$ (26.8 m). Gypsum mudstone unit. C) $114.6 \mathrm{ft}$ (34.9 m). Gypsum and carbonate mudstone unit with black nodules. D) $105.0 \mathrm{ft}(32.0 \mathrm{~m})$. Horizontal root traces in a gypsum mudstone. E) $174.3 \mathrm{ft}(53.1 \mathrm{~m})$. Plant or algal fragments in a mudstone. 

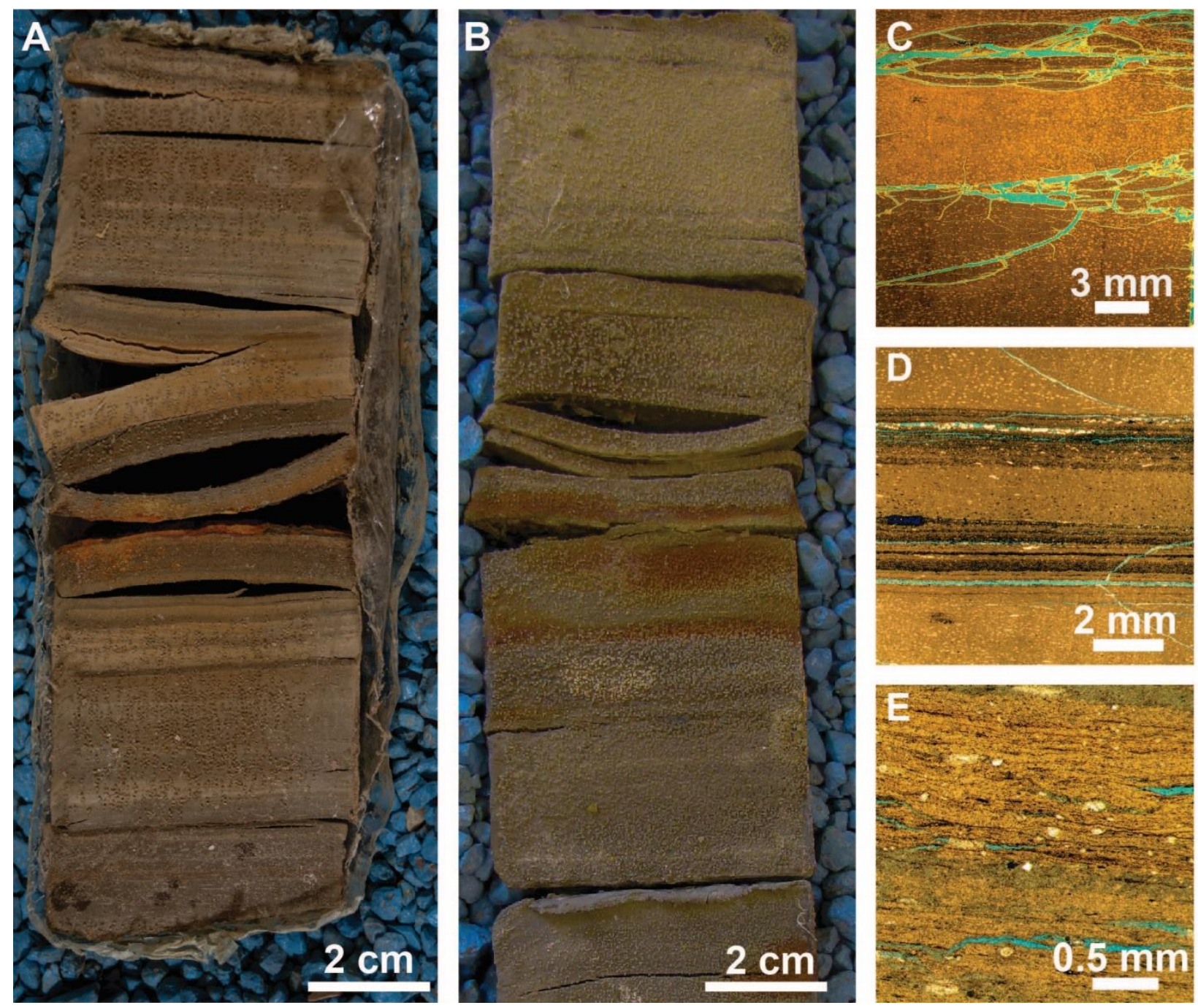

Figure 10. Laminated sliciclastic mudstones. A) $126.0 \mathrm{ft}$ (38.4 m). Laminated mudstone units. B) $121.5 \mathrm{ft}(37.0 \mathrm{~m})$. Laminated mudstone grading into siltstone. C) $121.7 \mathrm{ft}(37.1 \mathrm{~m})$. Horizontal root traces and an abundance of white dots on surface. D) $126.8 \mathrm{ft}$. Lamina composed of organics. E) $127.9 \mathrm{ft}$ (39.0 m). Wavy lamina made of organics with occasional silt grains within. 


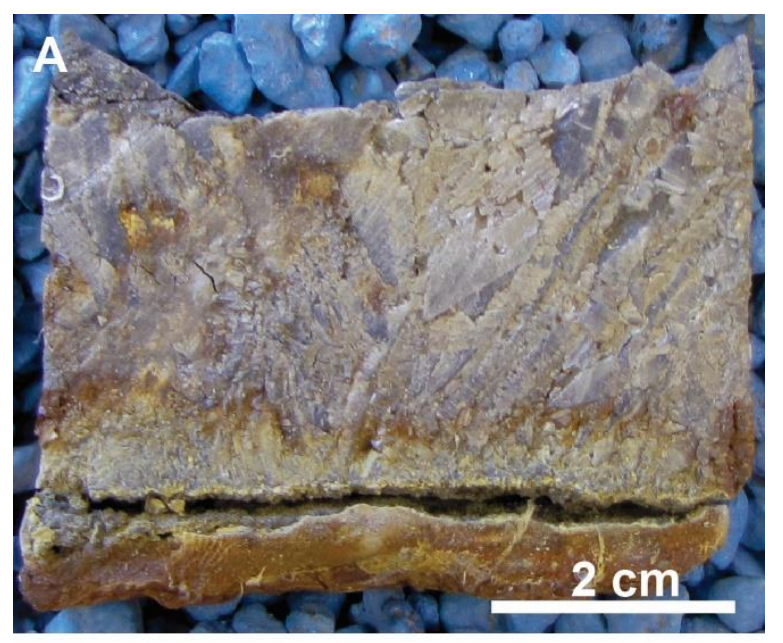

Figure 11. Gypsum breccia unit at $128.5 \mathrm{ft}$ (39.2 m). A) Core slab photo of gypsum breccia unit. B) Photomicrograph of gypsum breccia unit

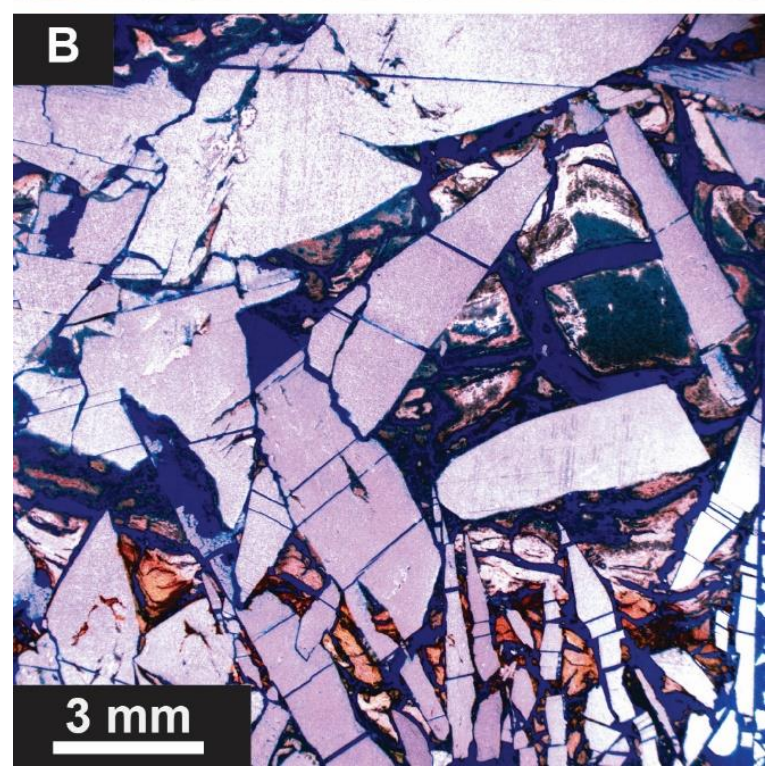



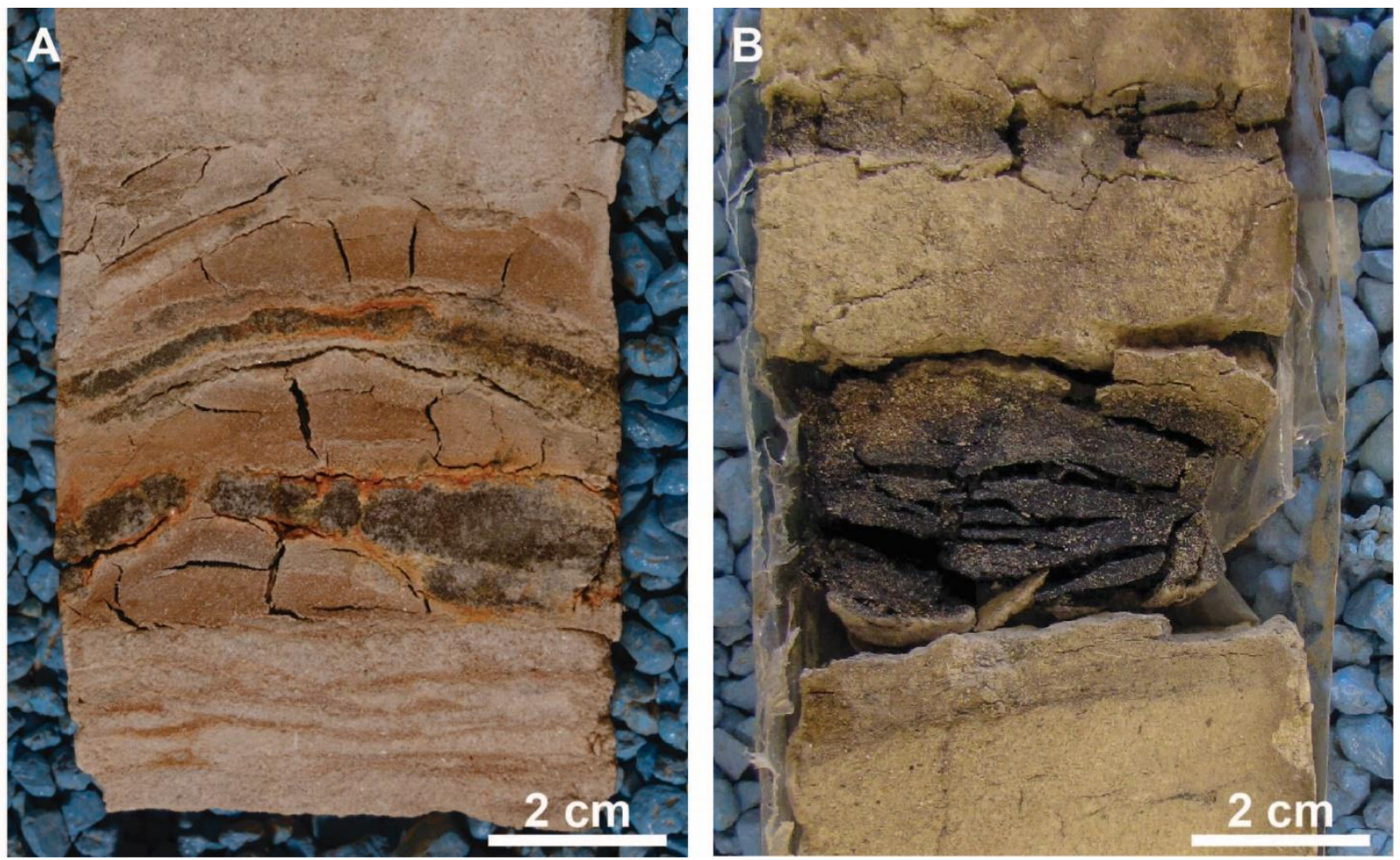

Figure 12. Core slab photos of black layers. A)180.2 ft (54.9 m). Two black layers between gypsum sand layers. B) $83.5 \mathrm{ft}(23.5 \mathrm{~m})$. Black layer surrounded by brackish to saline lake carbonate mudstones. 

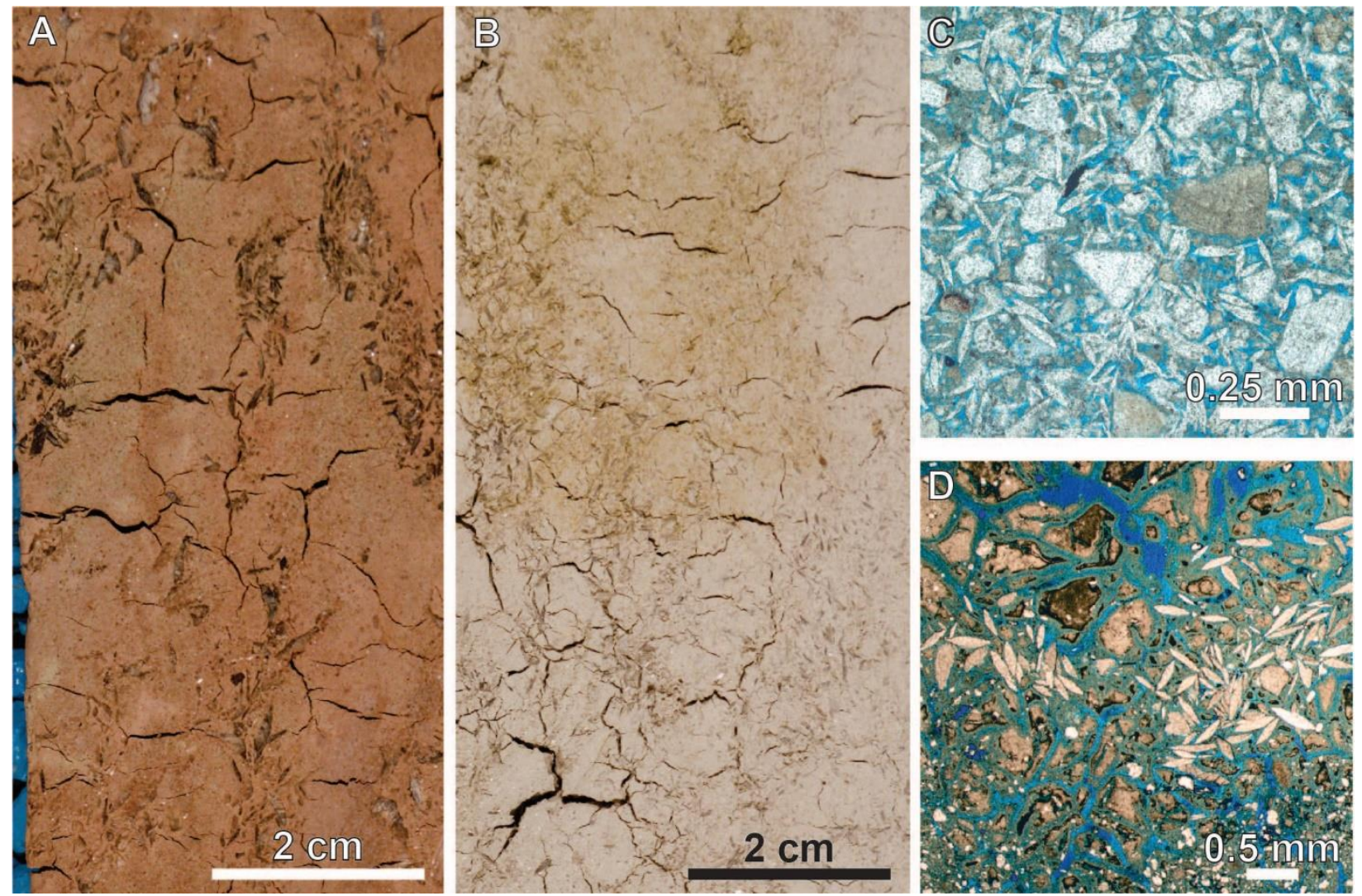

Figure 13. Displacive Gypsum core slab photos and photomicrographs. A) $159.0 \mathrm{ft}$ (48.5 m). Displacive gypsum crystals grown in a mixed siliciclastic - gypsum siltstone. B) $67.6 \mathrm{ft}$ (20.6 $\mathrm{m})$. Displacive gypsum grains in a gypsum mudstone. C) $80.0 \mathrm{ft}(24.4 \mathrm{~m})$. Photomicrograph of gypsum in mixed siliciclastic - gypsum sandstone and siltstone. D) $71.3 \mathrm{ft}(21.7 \mathrm{~m})$. Displacive gypsum in a muddy siltstone. 
perennial freshwater lake
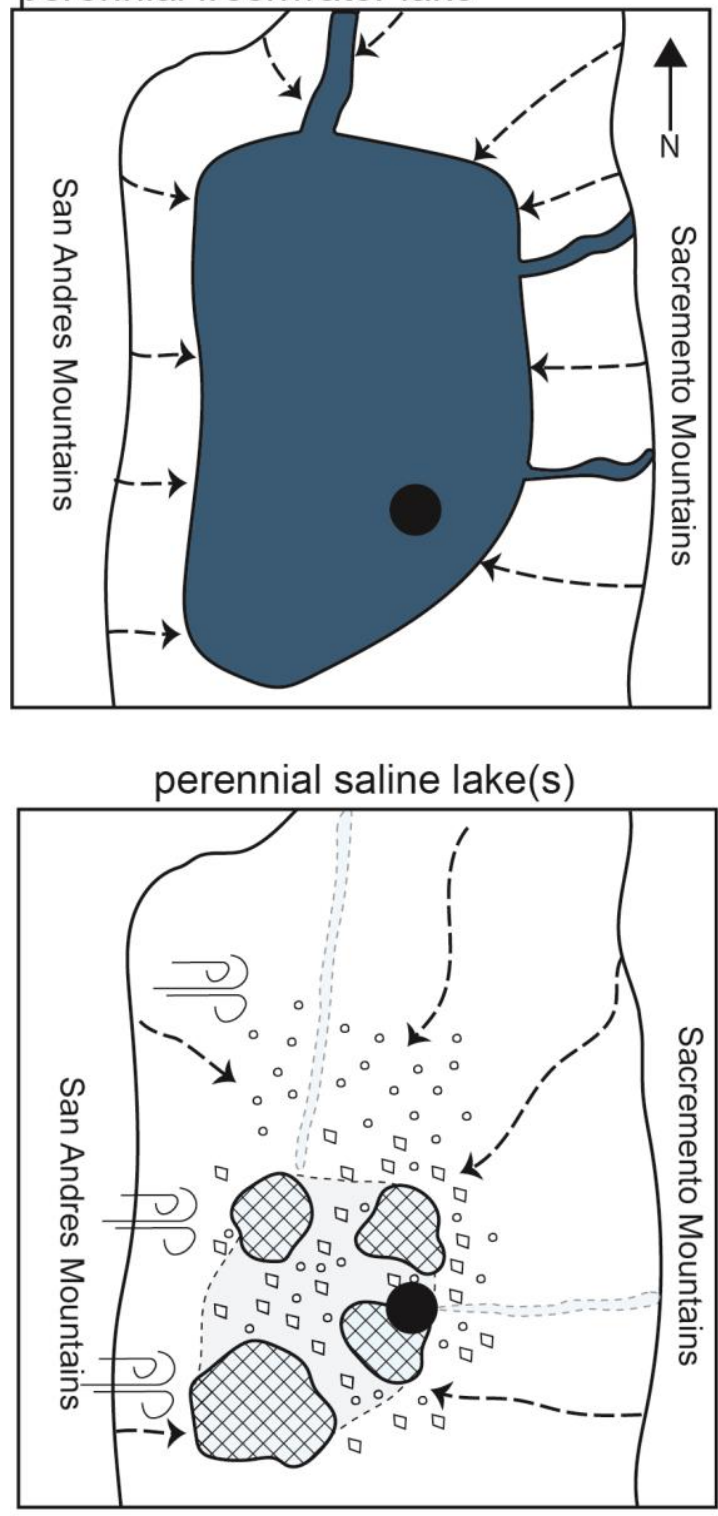

\section{$---\rightarrow$ groundwater input}

perennial brackish to saline lake

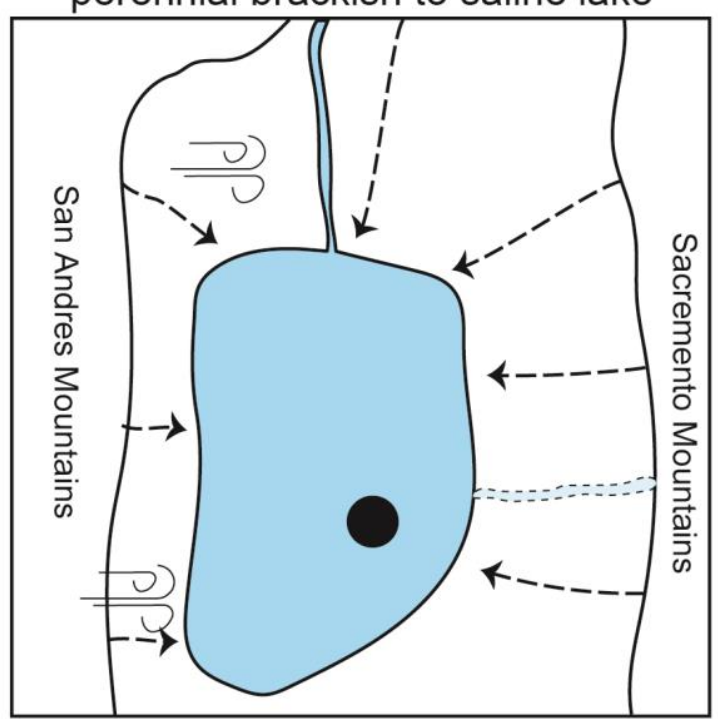

ephemeral lake + eolian processes

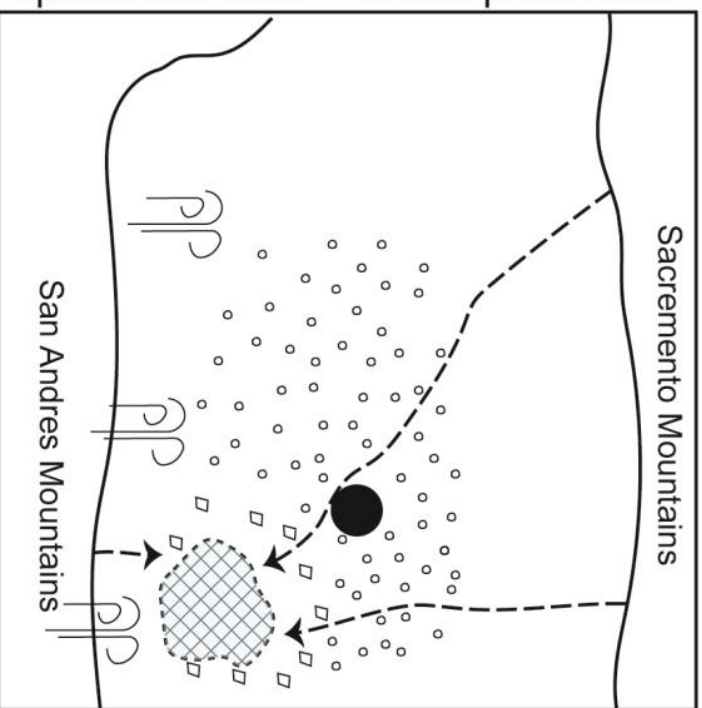

approximate core location

Figure 14. Schematic of four stages of deposition at White Sands. A) Perennial freshwater lake stage which results in deposition of siliciclastic pure units. B) Brackish to saline lake stage with carbonate and gypsum deposition. C) Saline lake stage which would result in significant bottom-growth and displacive gypsum. This could be several small saline lakes or one relatively large saline lake. Eolian processes would rework some gypsum. D) Ephemeral lake and eolian stage. Abundant gypsum sand would be deposited in sandflats through eolian processes. Ephemeral crusts would form at ephemeral lake and displacive gypsum would grow in the subsurface. 


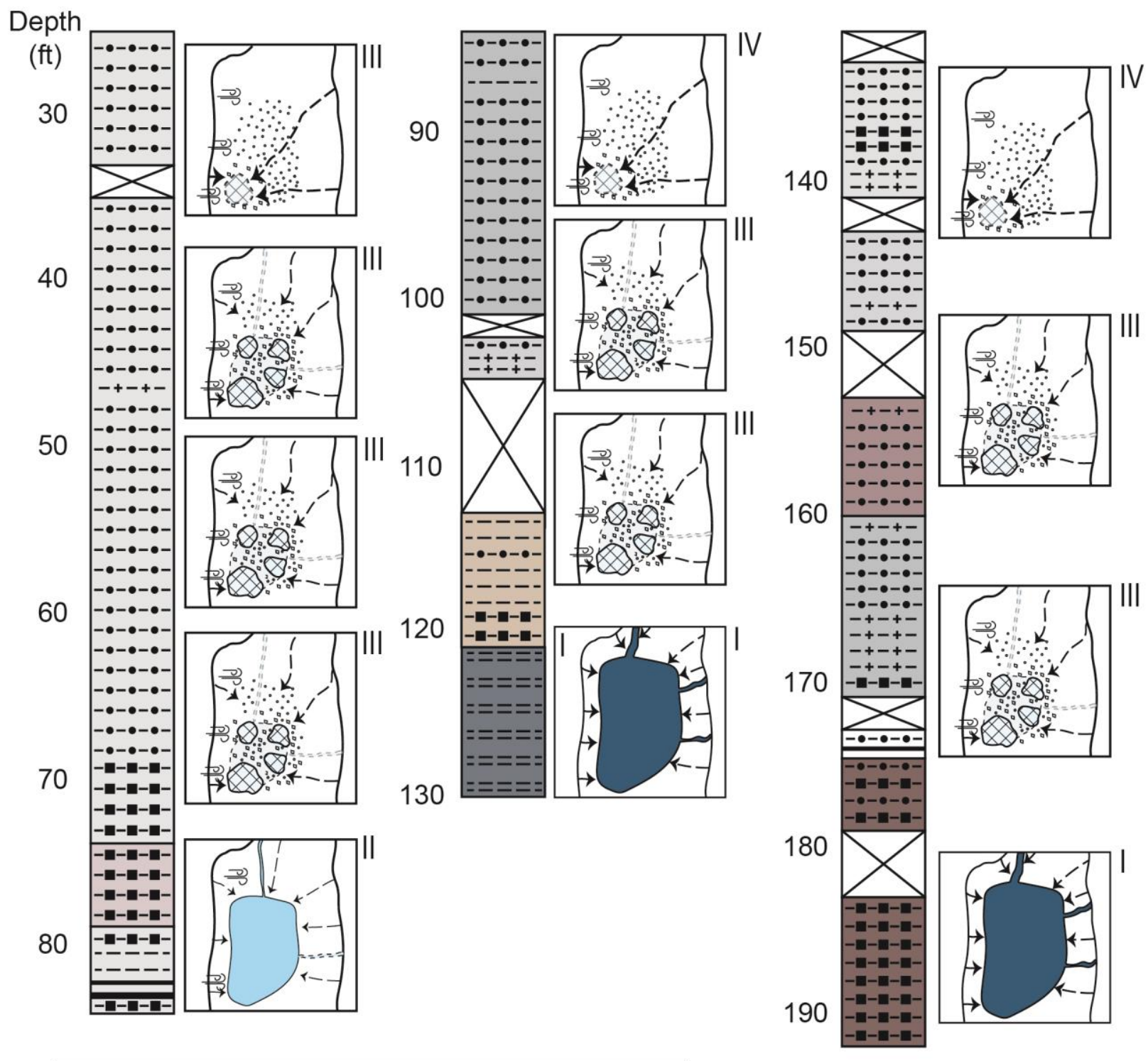

\begin{tabular}{|ll|}
\hline \multicolumn{1}{|c|}{ LITHOLOGIES } & $\begin{array}{l}\text { laminated } \\
\text { mypsum sandstone } \\
\text { and siltstone }\end{array}$ \\
$\begin{array}{l}\text { siliciclastic }(>10 \%) \\
\text { and gypsum siltstone } \\
\text { and sandstone }\end{array}$ & black layers \\
carbonate \\
mudstone
\end{tabular}

Figure 15. Measured Section with depositional environment stages from figure 14 relative to core. (I) perennial freshwater lake (II) perennial brackish to saline lake (III) perennial saline lake(s) (IV) ephemeral saline lake(s) and associated environments 


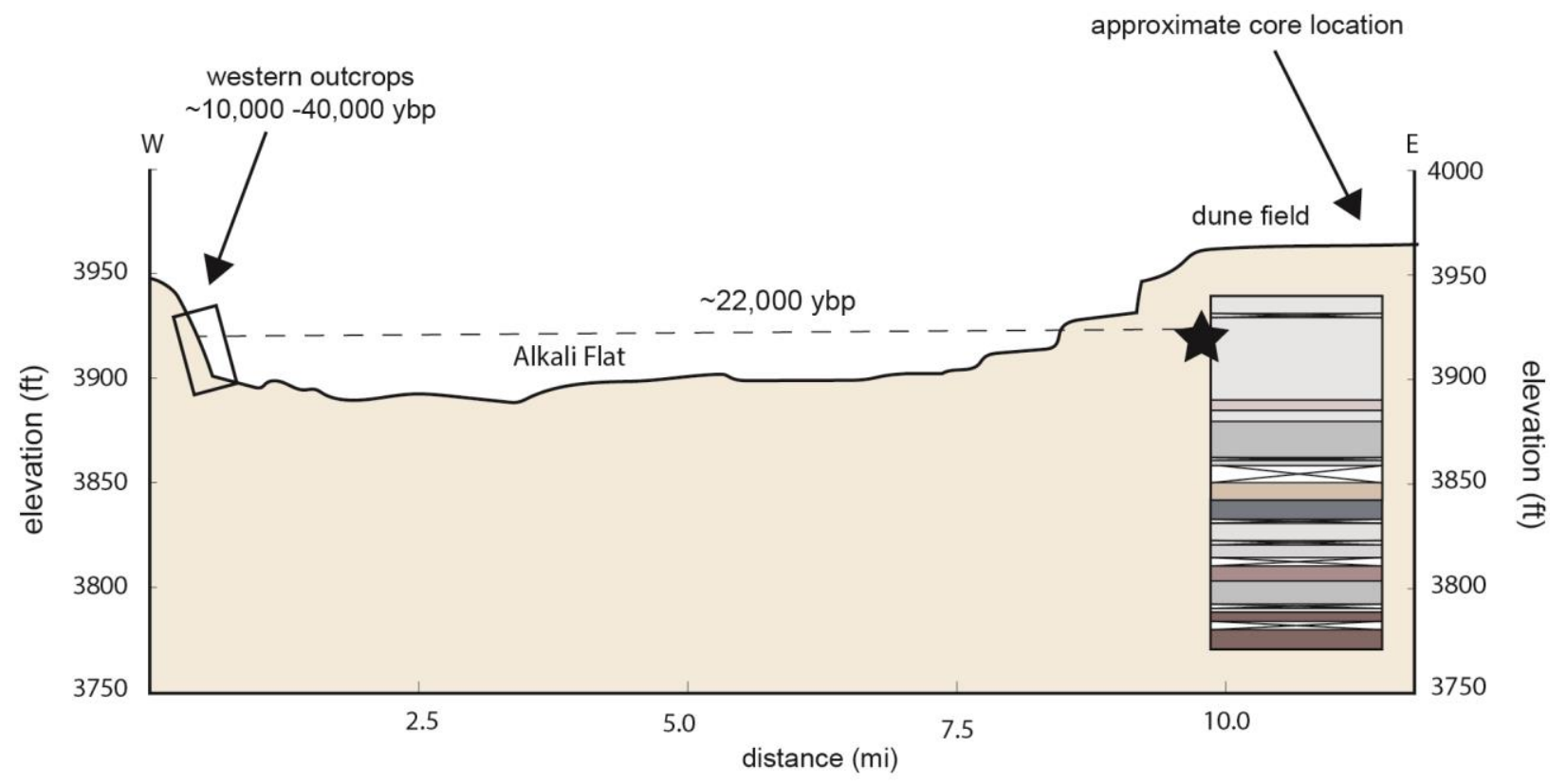

Figure 16. Topographic profile from Google Earth showing location and depth of core relative to the western outcrops. Black star is depth of calibrated radiocarbon age. Western outcrop dates come from Allen, 2009 and Bustos et al. 2018. 


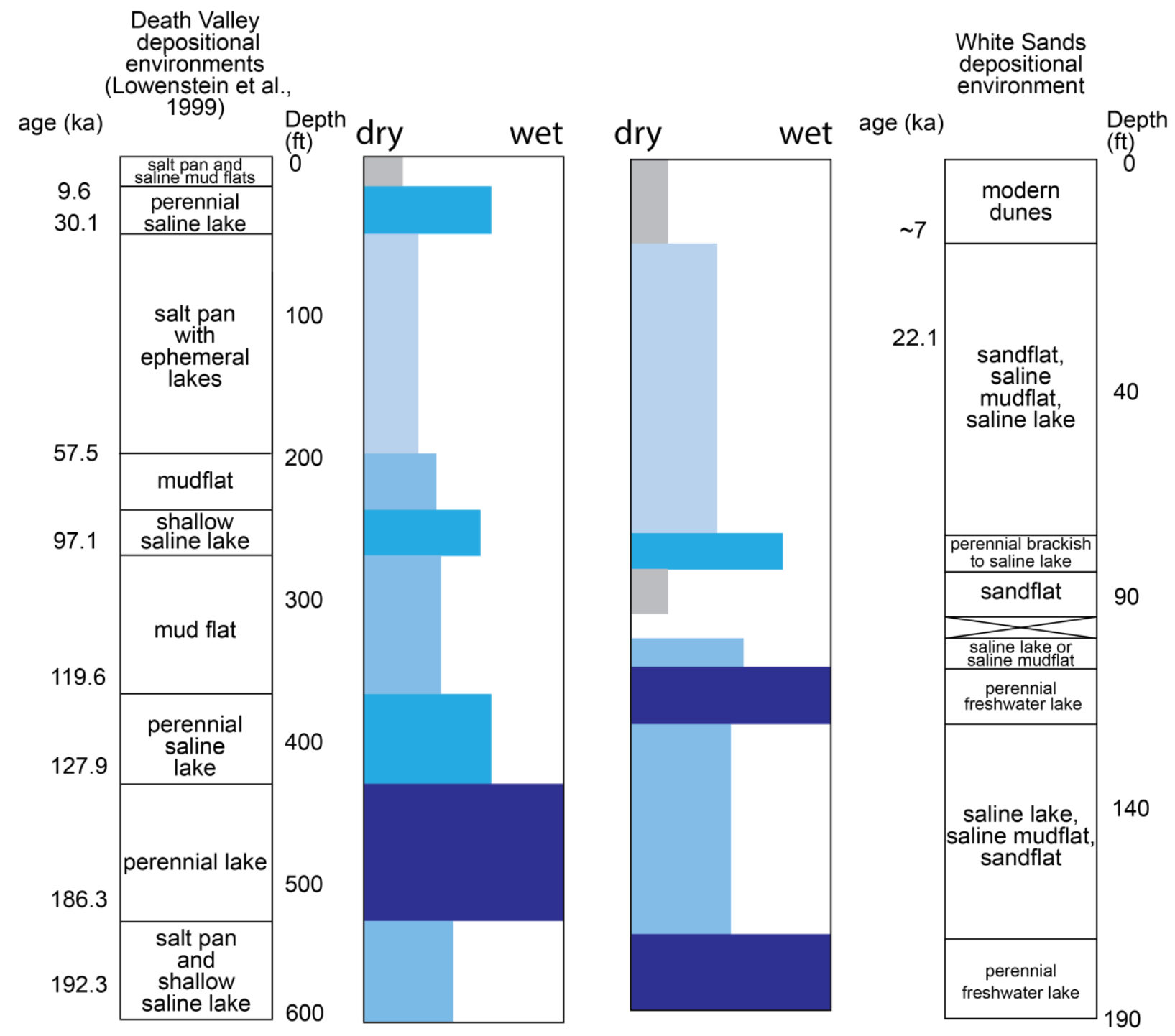

Figure 17. A comparison of depositional environments and approximated wet dry trends through time between Death Valley (Lowenstein et al, 1999) and the White Sands core mw-12-11. Note differences between time scales 


\section{Appendix 1 - Measured Section Details}

Measured section from 7 days at USGS CRC. Unless XRD is directly stated mineral composition is a visual estimate while working at the core lab.

unit: 1

depth (ft): $192.3-189.3$

lithology: silty, siliciclastic mudstone

color: medium red brown

grain composition: $11 \%$ quartz, $5.5 \% \mathrm{k}$-feldspar, $5.4 \%$ plagioclase, $4 \%$ calcite, $0.7 \%$ dolomite, $1.1 \%$ gypsum, $53 \%$ mixed-layer illite/smectite, $11 \%$ illite and mica, $7.2 \%$ kaolinite, $1.2 \%$

chlorite (from xrd at $190.2 \mathrm{ft}$ )

sedimentary textures: rounded silt grains

sedimentary structures: planar laminations, root traces

fossils: charcoal pieces, seeds

diagenetic features: none

other: surface salt precipitates

unit: 2

depth (ft): 189.3 - 189.2

lithology: carbonate mudstone

color: tan white

grain composition: (n/a)

sedimentary textures: (n/a)

sedimentary structures: convoluted

fossils: none

diagenetic features: none

other: strong reaction with $\mathrm{HCl}$

unit: 3

depth (ft): $189.2-188.0$

lithology: siliciclastic sandstone and siltstone

color: $\tan$

grain composition: siliciclastic

sedimentary textures: $40 \%$ very fine sand grains, $60 \%$ silt grains, subrounded - rounded grains sedimentary structures: laminations in upper 3 inches

fossils: none

diagenetic features: none

other: mild reaction with $\mathrm{HCl}$ with lamina in upper 3 inches 
unit: 4

depth (ft): $188.0-187.5^{\prime}$

lithology: siliciclastic sandstone and siltstone

color: $\tan$

grain composition: siliciclastic

sedimentary textures: $40 \%$ very fine sand, $60 \%$ silt, subrounded - rounded

sedimentary structures: lamina, cross laminations, wavy lamina

fossils: none

diagenetic features: none

other: mild reaction with $\mathrm{HCl}$ with lamina

unit: 5

depth (ft): $187.5-187.0$

lithology: siliciclastic (>10\%) and gypsum siltstone and sandstone

color: red brown

grain composition: $<1 \%$ gypsum, siliciclastic minerals

sedimentary textures: abraded platy gypsum, subrounded siliciclastic

sedimentary structures: cross and wavy lamina

fossils: none

diagenetic features: none

other: first gypsum grains identified

unit: 6

depth (ft): $187.0-185.5$

lithology: siliciclastic (>10\%) and gypsum siltstone and sandstone

color: tan brown

grain composition: $<5 \%$ gypsum, siliclastic minerals

sedimentary textures: very fine sand, platy abraded gypsum, subrounded siliclastics

sedimentary structures: lamina

fossils: none

diagenetic features: calcite cement

other: vigorous reaction with $\mathrm{HCl}$

unit: 7

depth (ft): $185.5-185.3$

lithology: siliciclastic (>10\%) and gypsum siltstone and sandstone

color: red grey brown

grain composition: siliciclastic

sedimentary textures: subrounded fine sand grains

sedimentary structures: none

fossils: charcoal pieces

diagenetic features: none

other: none 
unit: 8

depth (ft): $185.3-183.0$

lithology: siliciclastic (>10\%) and gypsum siltstone and sandstone

color: red grey brown

grain composition: siliciclastic, $<5 \%$ gypsum

sedimentary textures: platy gypsum grains, subrounded siliciclastic grains, silt grains, coarsens

upwards to fine sand

sedimentary structures: cross and wavy lamina

fossils: charcoal pieces

diagenetic features: none

other: none

unit: missing core

depth (ft): $183.0-179.1$

unit: 9

depth (ft): $179.1-178.0$

lithology: siliciclastic (>10\%) and gypsum sandstone and siltstone

color: white

grain composition: approximately $70 \%$ gypsum, $30 \%$ siliciclastic minerals

sedimentary textures: subrounded, fine sand grains

sedimentary structures: subtle cross and wavy lamina

fossils: none

diagenetic features: poorly cemented

other: none

unit: 10

depth (ft): $178.0-177.7$

lithology: gypsum sandstone and siltstone

color: grey

grain composition: gypsum

sedimentary textures: coarse, lightly abraded, angular, broken "books" and swallow tail pieces sedimentary structures: none

fossils: none

diagenetic features: none

other: none 
unit: 11

depth (ft): 177.7 - 177.3

lithology: gypsum sandstone with 20.5 inch black beds

color: tan white

grain composition: siliciclastic

sedimentary textures: coarse, medium, angular

sedimentary structures: wavy lamina

fossils: charcoal pieces

diagenetic features: none

other: black layers have sulfur and iron staining

unit: 12

depth (ft): $177.3-175.3$

lithology: siliciclastic (>10\%) and gypsum sandstone and siltstone

color: brown, red grey

grain composition: $75 \%$ gypsum, $25 \%$ siliciclastic minerals

sedimentary textures: $\sim 65 \%$ silt grains, $35 \%$ sand grains, coarsens upwards, subangular sedimentary structures: cross and wavy lamina

fossils: none

diagenetic features: none

other: none

unit: 13

depth (ft): $175.3-175.0$

lithology: gypsum mudstone

color: pale grey

grain composition: $75 \%$ gypsum, $25 \%$ siliciclastic minerals

sedimentary textures: few gypsum silt grains

sedimentary structures: wavy lamina

fossils: none

diagenetic features: none

other: abundant surface salt precipitates

unit: 14

depth (ft): $175.3-175.0$

lithology: siliciclastic (>10\%) and gypsum sandstone and siltstone

color: red brown grey

grain composition: $\mathrm{n} / \mathrm{a}$

sedimentary textures: mud size grains, silt grains, and very few fine sand grains sedimentary structures: few wavy lamina

fossils: none

diagenetic features: none

other: abundant surface salt precipitates, single $1.5 \mathrm{~cm}$ "book" gypsum piece 
unit: 15

depth (ft): 174.3 - 174.2

lithology: siliciclastic (>10\%) and gypsum sandstone and siltstone

color: white

grain composition: $n / a$

sedimentary textures: fine sand, rounded

sedimentary structures: few wavy lamina

fossils: none

diagenetic features: none

other: none

unit: 16

depth (ft): $174.2-174.1$

lithology: bedded bottom-growth gypsum

color: grey

grain composition: gypsum

sedimentary textures: vertically oriented gypsum crystals $\sim 0.6$ inch in height, thin layer of

sand on top of crystals

sedimentary structures: none

fossils: none

diagenetic features: none

other: none

unit: 17

depth (ft): 174.1 - 173.9

lithology: siliciclastic (>10\%) and gypsum sandstone and siltstone

color: tan

grain composition: $n / a$

sedimentary textures: silt sized grains, rounded

sedimentary structures: abundant wavy lamina

fossils: none

diagenetic features: none

other: none

unit: 18

depth (ft): $173.9-173.8$

lithology: siliciclastic (>10\%) and gypsum sandstone and siltstone

color: tan

grain composition: $75 \%$ gypsum, $25 \%$ siliciclastic minerals

sedimentary textures: fine sand, blocky gypsum, rounded siliciclastics

sedimentary structures: none

fossils: none

diagenetic features: white intergranular cement

other: none 
unit: missing

depth (ft): $173.8-171.8$

unit: 19

depth (ft): $171.8-171.2$

lithology: siliciclastic (>10\%) and gypsum sandstone and siltstone

color: $\tan$

grain composition: $75 \%$ gypsum, $25 \%$ siliciclastic minerals

sedimentary textures: fine sand, blocky gypsum, rounded siliciclastics

sedimentary structures: none

fossils: none

diagenetic features: white intergranular cement, less well cemented at top

other: similar to unit 18

unit: 20

depth (ft): $171.2-170.5$

lithology: siliciclastic (>10\%) and gypsum sandstone and siltstone

color: $\tan$

grain composition: $90 \%$ gypsum, $10 \%$ siliciclastic minerals

sedimentary textures: poorly sorted silt to coarse sand, blocky to angular gypsum, rounded

siliciclastics

sedimentary structures: none

fossils: none

diagenetic features: white intergranular cement, less well cemented at top

other: gypsum has brown tinge

unit: 21

depth (ft): $170.5-169.5$

lithology: gypsum mudstone

color: grey

grain composition: $n / a$

sedimentary textures: mud grains

sedimentary structures: few lamina near top

fossils: none

diagenetic features: none

other: scratches easily with fingernail

unit: 22

depth (ft): $169.5-167.9$

lithology: gypsum mudstone

color: red brown

grain composition: $n / a$

sedimentary textures: mud grains

sedimentary structures: pocket of gypsum sand,

fossils: none

diagenetic features: fine gypsum veins

other: abundant surface salts 
unit: 23

depth (ft): $167.5-167.7$

lithology: gypsum mudstone

color: red brown

grain composition: gypsum sand and silt

sedimentary textures: mud grains, fine sand and silt near top of unit, sand is sorted blocky

gypsum

sedimentary structures: pocket of gypsum sand,

fossils: none

diagenetic features: displacive near base

other: none

unit: 24

depth (ft): $167.7-167.6$

lithology: bedded bottom-growth gypsum

color: light grey

grain composition: gypsum

sedimentary textures: vertically oriented gypsum crystals $0.1-0.3$ inches in height

sedimentary structures: multiple beds of bottom-growth gypsum separated by gypsum sand

fossils: none

diagenetic features: none

other: none

unit: 25

depth (ft): $167.6-167.5$

lithology: gypsum sandstone and siltstone

color: light brown

grain composition: gypsum

sedimentary textures: silt grains, coarsens upwards to fine sand, blocky

sedimentary structures: none

fossils: none

diagenetic features: none

other: possible 0.1-inch bottom-growth layer, abundant surface salt precipitates

unit: 26

depth (ft): $167.5-161.4$

lithology: gypsum sandstone and siltstone

color: light brown

grain composition: gypsum

sedimentary textures: varies between silt and fine sand, generally fines upwards, single layer of 1-2 mm angular interlocked gypsum sand

sedimentary structures: planar, wavy, and cross lamina,

fossils: none

diagenetic features: gypsum veins

other: surface salt precipitates become more abundant moving upwards 
unit: 27

depth (ft): $161.4-161.0$

lithology: gypsum sandstone and siltstone

color: grey

grain composition: gypsum

sedimentary textures: coarse, angular, lightly abraded

sedimentary structures: none

fossils: none

diagenetic features: gypsum veins

other: possibly several layers of 0.1 -inch bottom growth crystals

unit: 28

depth (ft): $161.0-160.2$

lithology: gypsum mudstone

color: grey

grain composition: gypsum

sedimentary textures: $\mathrm{n} / \mathrm{a}$

sedimentary structures: wavy lamina

fossils: none

diagenetic features: none

other: none

unit: 29

depth (ft): $160.2-157.0$

lithology: siliciclastic (>10\%) and gypsum sandstone and siltstone

color: red

grain composition: $n / a$

sedimentary textures: very fine sand with few coarse grains

sedimentary structures: wavy lamina

fossils: none

diagenetic features: $1-3 \mathrm{~mm}$ lenticular displacive gypsum

other: none

unit: 30

depth (ft): $157.0-156.5$

lithology: gypsum sandstone and siltstone

color: grey

grain composition: gypsum

sedimentary textures: fine sand with few coarse grains, more silt at top of unit sedimentary structures: wavy discontinuous lamina

fossils: none

diagenetic features: none

other: secondary surface salt precipitates 
unit: 31

depth (ft): $156.5-154.2$

lithology: gypsum sandstone and siltstone

color: red brown

grain composition: gypsum

sedimentary textures: silt at base, grades to fine sand grains, moderately - well sorted sedimentary structures: wavy discontinuous lamina near base

fossils: none

diagenetic features: none

other: none

unit: 32

depth (ft): $154.2-153.4$

lithology: gypsum mudstone

color: grey

grain composition: gypsum

sedimentary textures: none

sedimentary structures: wavy discontinuous lamina near base

fossils: none

diagenetic features: none

other: easy to scratch with fingernail, surface salt precipitates

unit: 33

depth (ft): $153.4-153.0$

lithology: gypsum sandstone and siltstone

color: grey

grain composition: gypsum

sedimentary textures: silt grains at base coarsens upwards to medium sand grains, few $3 \mathrm{~mm}$ grains scattered throughout

sedimentary structures: lamina that are iron and sulfur stained

fossils: none

diagenetic features: none

other: easy to scratch with fingernail, surface salt precipitates

unit: missing

depth (ft): $153.0-148.7$ 
unit: 34

depth (ft): 148.7 - 147.8

lithology: gypsum sandstone and siltstone

color: grey

grain composition: gypsum

sedimentary textures: silt grains, some fine sand grains

sedimentary structures: ripple lamina

fossils: none

diagenetic features: none

other: iron and sulfur staining along laminations

unit: 35

depth (ft): $147.8-147.5$

lithology: gypsum sandstone and siltstone

color: grey

grain composition: gypsum

sedimentary textures: fine sand grains, blocky grains

sedimentary structures: none

fossils: none

diagenetic features: none

other: none

unit: 36

depth (ft): 147.5 - 146.3

lithology: gypsum mudstone

color: grey

grain composition: gypsum

sedimentary textures: $\mathrm{n} / \mathrm{a}$

sedimentary structures: none

fossils: none

diagenetic features: none

other: powdery yellow along crack with gypsum needles surrounding, sulfur and iron staining

unit: 37

depth (ft): $146.3-146.0$

lithology: gypsum sandstone and siltstone

color: grey

grain composition: gypsum

sedimentary textures: fine sand

sedimentary structures: none

fossils: none

diagenetic features: intergranular

other: none 
unit: 38

depth (ft): $146.0-145.3$

lithology: gypsum sandstone and siltstone

color: light grey

grain composition: gypsum

sedimentary texture: fine to coarse sand, some grains up to $5 \mathrm{~mm}$ with "book" texture sedimentary structures: none

fossils: none

diagenetic features: none

other: none

unit: 39

depth (ft): $145.3-143.5$

lithology: gypsum sandstone and siltstone

color: light white

grain composition: gypsum

sedimentary textures: silt grains, $10-15 \%$ fine sand, coarsens upwards to $25 \%$ sand sedimentary structures: wavy lamina, some discontinous

fossils: none

diagenetic features: none

other: none

unit: 40

depth (ft): $143.5-143.0$

lithology: gypsum sandstone and siltstone

color: light tan

grain composition: gypsum

sedimentary textures: silt grains

sedimentary structures: wavy discontinuous lamina

fossils: none

diagenetic features: $1-2$ inch gypsum crystals

other: none

unit: missing

depth (ft): 143.0 - 141.4

unit: 41

depth (ft): $141.4-140.8$

lithology: gypsum mudstone

color: grey

grain composition: $n / a$

sedimentary textures: none

sedimentary structures: none

fossils: none

diagenetic features: none

other: abundant surface salt precipitates 
unit: 42

depth (ft): $140.8-140.2$

lithology: gypsum mudstone

color: grey

grain composition: $n / a$

sedimentary texture: none

sedimentary structures: lamina

fossils: none

diagenetic features: none

other: surface salt precipitates

unit: 42

depth (ft): $140.8-140.2$

lithology: gypsum mudstone

color: grey

grain composition: $\mathrm{n} / \mathrm{a}$

sedimentary texture: none

sedimentary structures: lamina

fossils: none

diagenetic features: none

other: surface salt precipitates

unit: 43

depth (ft): $140.2-139.7$

lithology: gypsum sandstone and siltstone

color: red grey

grain composition: gypsum

sedimentary textures: fine sand grains, $90 \%$ gypsum, $10 \%$ siliciclastic minerals

sedimentary structures: vertical root traces filled with gypsum mud grains

fossils: none

diagenetic features: none

other: surface salt precipitates

unit: 44

depth (ft): $139.7-137.5$

lithology: siliciclastic (>10\%) and gypsum sandstone and siltstone

color: red grey

grain composition: $90 \%$ gypsum, $10 \%$ siliciclastic minerals

sedimentary textures: subrounded - subangular, moderately sorted

sedimentary structures: vertical root traces filled with gypsum mud grains

fossils: none

diagenetic features: reduction spots?

other: surface salt precipitates 
unit: 45

depth (ft): $137.5-133.7$

lithology: gypsum sandstone and siltstone

color: red grey

grain composition: $95 \%$ gypsum, $5 \%$ siliciclastic minerals

sedimentary textures: subrounded - subangular, moderately sorted, coarsens upwards from fine sand to medium sand

sedimentary structures: single suspect root trace

fossils: none

diagenetic features: suspect reduction spots

other: base reacts with acid, iron and sulfur stained band

unit: 46

depth (ft): $133.7-133.2$

lithology: gypsum sandstone and siltstone

color: red grey

grain composition: gypsum

sedimentary textures: poorly sorted, fine to pebble size grains, lightly abraded grains, some

platy gypsum grains, some grains had partial swallow tail shapes

sedimentary structures: none

fossils: none

diagenetic features: none

other: grains were tightly packed

unit: 47

depth (ft): $133.2-133.0$

lithology: gypsum sandstone and siltstone

color: red grey

grain composition: gypsum

sedimentary textures: $50 \%$ silt abraded, blocky, 50\% lightly abraded angular sand, grains up to $3 \mathrm{~mm}$ at top of unit

sedimentary structures: none

fossils: none

diagenetic features: none

other: none

unit: missing

depth (ft): $133.0-130.9$ 
unit: 48

depth (ft): $130.9-129.0$

lithology: gypsum sandstone and siltstone

color: white, grey

grain composition: gypsum

sedimentary textures: poorly sorted, fine sand to pebble sized grains, suspect swallow tail shapes, platy grains, angular grains, top 1.5" of unit is more well sorted and fine sand.

sedimentary structures: none

fossils: none

diagenetic features: patchy white and grey cements

other: patchy $\mathrm{HCl}$ reaction with cement

unit: 49

depth (ft): $129.0-128.6$

lithology: laminated siliciclastic mudstone

color: grey

grain composition: $\mathrm{n} / \mathrm{a}$

sedimentary textures: mud size grains

sedimentary structures: lamina

fossils: none

diagenetic features: $\mathrm{n} / \mathrm{a}$

other: abundant surface salt precipitants

unit: 50

depth (ft): $128.6-128.5$

lithology: gypsum breccia

color: grey

grain composition: gypsum crystals, mud unknown

sedimentary textures: mud size grains, gypsum crystals up to 1", some prismatic with points at both ends

sedimentary structures: few gypsum crystals aligned vertically

fossils: none

diagenetic features: $\mathrm{n} / \mathrm{a}$

other: significant sulfur and iron staining 
unit: 51

depth (ft): $128.5-121.6$

lithology: laminated siliciclastic mudstone

color: grey/white

grain composition: from XRD at $122.4 \mathrm{ft}$ : Quartz 14.2\%, K-Feldspar 7.9\%, Plagioclase 6.7\%, Calcite $1.4 \%$, Dolomite $1.1 \%$, pyrite $1.6 \%$, gypsum 1.6\%, mixed layer Illite/Smectite with $90 \%$ Smectite layers $41.8 \%$, Illite and Mica $14.2 \%$, Chlorite $1.9 \%$

sedimentary textures: few silt grains identified in thin section

sedimentary structures: roots traces identified in thin section, $<0.1 \mathrm{~mm}$ eye shaped dots

identified in thin section, coarsens at the top

fossils: none

diagenetic features: $n / a$

other: gradational contact with unit 52

unit: 52

depth (ft): $121.6-119.1$

lithology: siliciclastic (>10\%) and gypsum sandstone and siltstone

color: $\tan$

grain composition: 70 - 80\% gypsum, 20 - 30\% siliciclastic minerals

sedimentary textures: frosted blocky gypsum silt, moderately sorted, silt and fine sand grains, coarsens upwards

sedimentary structures: coarsens near top, cross and wavy lamina, dewatering structure near top of unit

fossils: charcoal fragments

diagenetic features: $n / a$

other: mild reaction with $\mathrm{HCl}$ in bottom foot

unit: 53

depth (ft): $119.1-113.6$

lithology: carbonate mudstone

color: red grey

grain composition: $n / a$

sedimentary textures: frosted blocky gypsum silt, moderately sorted, silt and fine sand grains, coarsens upwards

sedimentary structures: $<0.1 \mathrm{~mm}$ eye shaped dots, 1 foot bed of fine gypsum sand near base of unit

fossils: none

diagenetic features: few iron concretions

other: reaction with $\mathrm{HCl}$, heavy salt surface precipitates 
unit: 54

depth (ft): $113.6-113.0$

lithology: gypsum mudstone

color: pale red grey

grain composition: $n / a$

sedimentary textures: $\mathrm{n} / \mathrm{a}$

sedimentary structures: $n / a$

fossils: none

diagenetic features: 3 clusters of gypsum grains up to $1 \mathrm{~mm}$

other: abundant salt surface precipitates

unit: missing

depth (ft): $113.0-105.9$

unit: 55

depth (ft): 105.9 - 105.7

lithology: gypsum mudstone

color: red grey

grain composition: few gypsum sand grains near top

sedimentary textures: angular gypsum sand $1-3 \mathrm{~mm}$

sedimentary structures: convoluted structure, suspect mudcracks

fossils: none

diagenetic features: few iron concretions

other: none

unit: 56

depth (ft): $105.7-104.9$

lithology: gypsum mudstone

color: grey

grain composition: $n / a$

sedimentary textures: bottom 1.5" of unit contains fine gypsum sand

sedimentary structures: laminated mudstone, forms intraclasts in overlying unit

fossils: none

diagenetic features: none

other: abundant surface salt precipitates

unit: 57

depth (ft): $104.9-103.2$

lithology: siliciclastic (>10\%) and gypsum sandstone and siltstone

color: red

grain composition: $85 \%$ gypsum, $10 \%$ siliciclastic minerals

sedimentary textures: fine sand grains, well sorted, coarsens to medium to coarse grains near top, blocky gypsum, rounded siliciclastics

sedimentary structures: laminated mudstone, forms intraclasts in overlying unit

fossils: none

diagenetic features: none 
other: undulating contact with 58

unit: 58

depth (ft): $103.2-103.0$

lithology: gypsum sandstone and siltstone

color: grey

grain composition: gypsum

sedimentary textures: fine sand grains, well sorted, coarsens to medium to coarse grains near top, blocky gypsum, rounded siliciclastics, suspect bottom growth gypsum

sedimentary structures: bedded defined by alternations of fine and medium fine gypsum grains

fossils: none

diagenetic features: gypsum cement

other: none

unit: missing

depth (ft): $103.0-101.7$

unit: 59

depth (ft): $101.7-94.6$

lithology: gypsum sandstone and siltstone

color: grey and white

grain composition: gypsum

sedimentary textures: coarse grains, beds are well sorted,

sedimentary structures: 0.4 " beds defined by slight alteration of grain size

fossils: none

diagenetic features: limited gypsum cement

other: none

unit: 60

depth (ft): $94.6-91.5$

lithology: gypsum sandstone and siltstone

color: grey and white

grain composition: gypsum

sedimentary textures: bimodal grain size distribution, coarse and fine sand, coarse grains are angular with some cleavage faces, fine grains are abraded and blocky

sedimentary structures: none

fossils: none

diagenetic features: $n / a$

other: none 
unit: 61

depth (ft): $91.5-90.0$

lithology: gypsum sandstone and siltstone

color: grey and white

grain composition: gypsum

sedimentary textures: bimodal grain size, coarse and fine sand, grains are mostly lenticular, sedimentary structures: some imbrication of grains

fossils: none

diagenetic features: $n / a$

other: none

unit: 62

depth (ft): $90.0-88.4$

lithology: gypsum sandstone and siltstone

color: grey and white

grain composition: gypsum

sedimentary textures: coarse - very coarse, few medium grains, poorly sorted, unabraded platy grains, medium grains are blocky and abraded

sedimentary structures: none

fossils: none

diagenetic features: gypsum cement

other: none

unit: 63

depth (ft): $88.4-87.8$

lithology: gypsum mudstone

color: grey and white

grain composition: $10 \%$ gypsum sand

sedimentary textures: fine sand is moderately sorted, clear and abraded grains

sedimentary structures: suspect mudcracks

fossils: none

diagenetic features: none

other: none

unit: 64

depth (ft): $88.4-84.6$

lithology: gypsum sandstone and siltstone

color: grey and white

grain composition: gypsum

sedimentary textures: poorly sorted, fine to pebble size grains, suspect swallowtail grains, abraded and unabraded grains

sedimentary structures: suspect mudcracks

fossils: none

diagenetic features: $\mathrm{n} / \mathrm{a}$

other: none 
unit: 65

depth (ft): $84.6-84.0$

lithology: gypsum sandstone and siltstone

color: grey and white

grain composition: gypsum

sedimentary textures: poorly sorted, silt to medium sand, lenticular grains, blocky grains abraded and unabraded

sedimentary structures: none

fossils: none

diagenetic features: $n / a$

other: none

unit: 66

depth (ft): $84.0-83.5$

lithology: carbonate mudstone with 1 " black bed

color: $\tan$

grain composition: limited gypsum grains

sedimentary textures: gypsum grains are fine sand size

sedimentary structures: none

fossils: charcoal fragments, seeds

diagenetic features: displacive gypsum

other: vigorous reaction with $\mathrm{HCl}$

unit: 67

depth (ft): $83.5-83.0$

lithology: carbonate mudstone

color: $\tan$

grain composition: $n / a$

sedimentary textures: $n / a$

sedimentary structures: none

fossils: seeds, ostracods and charophytes identified in thin section

diagenetic features: displacive gypsum

other: vigorous reaction with $\mathrm{HCl}$

unit: missing

depth (ft): $83.0-82.7$ 
unit: 68

depth (ft): $82.7-82.5$

lithology: carbonate mudstone

color: $\tan$

grain composition: $<5 \%$ gypsum

sedimentary textures: fine gypsum sand

sedimentary structures: none

fossils: seeds, fibrous brown material, stringy black material

diagenetic features: displacive gypsum

other: vigorous reaction with $\mathrm{HCl}$

unit: 69

depth (ft): $82.5-80.3$

lithology: carbonate mudstone

color: $\tan$

grain composition: $30 \%$ gypsum silt, limited siliciclastic minerals near top of unit

sedimentary textures: gypsum silt is blocky and abraded

sedimentary structures: suspect dewatering structure, wavy lamina, mudcracks, coarsens

upward

fossils: charcoal bits

diagenetic features: few displacive gypsum crystals

other: vigorous reaction with $\mathrm{HCl}$

unit: 70

depth (ft): $80.3-75.3$

lithology: siliciclastic and gypsum sandstone and siltstone

color: pink grading to white

grain composition: $30 \%$ gypsum silt, limited siliciclastic minerals near top of unit

sedimentary textures: fine sand, subrounded, sortedness increases moving upwards

sedimentary structures:

fossils: none

diagenetic features: carbonate cement

other: cement reacts vigorously with $\mathrm{HCl}$

unit: 71

depth (ft): $75.3-73.7$

lithology: siliciclastic and gypsum sandstone and siltstone

color: white

grain composition: $90 \%$ gypsum, $10 \%$ siliciclastics

sedimentary textures: well sorted, fine sand

sedimentary structures: suspect root traces

fossils: seeds

diagenetic features: carbonate cement, clusters of displacive gypsum

other: cement reacts vigorously with $\mathrm{HCl}$ 
unit: missing

depth (ft): $73.7-73.0$

unit: 72

depth (ft): $73.0-71.6$

lithology: siliciclastic and gypsum sandstone and siltstone

color: $\tan$

grain composition: $60 \%$ gypsum, $40 \%$ siliciclastics

sedimentary textures: fine sand grains, bimodal grain size distribution, subangular to

subrounded, abraded to unabraded, abraded - clear gypsum

sedimentary structures: suspect root traces

fossils: none

diagenetic features: carbonate cement

other: cement reacts vigorously with $\mathrm{HCl}$

unit: 73

depth (ft): $71.6-69.6$

lithology: siliciclastic and gypsum sandstone and siltstone

color: $\tan$

grain composition: gypsum

sedimentary textures: fine sand grains, fines upwards to silt sized grains, lenticular gypsum

grains

sedimentary structures: none

fossils: none

diagenetic features: carbonate cement, displacive gypsum

other: cement reacts vigorously with $\mathrm{HCl}$

unit: 74

depth (ft): $69.6-65.3$

lithology: gypsum mudstone

color: grey

grain composition: gypsum

sedimentary textures: $\mathrm{n} / \mathrm{a}$

sedimentary structures: none

fossils: fibrous organics, seeds, greatest abundance of organics found in core

diagenetic features: displacive gypsum

other: vigorous reaction with $\mathrm{HCl}$ at base, none at top, 100 micron yellow mineral, surface is

highly cracked 
unit: 75

depth (ft): $65.3-65.2$

lithology: gypsum sandstone and siltstone

color: grey

grain composition: gypsum

sedimentary textures: lightly reworked displacive grains $<1 \mathrm{~mm}$

sedimentary structures: none

fossils: fibrous organics, seeds,

diagenetic features: displacive gypsum, carbonate cement

other: cement reacts with $\mathrm{HCl}$

unit: 76

depth (ft): $65.2-64.0$

lithology: gypsum sandstone and siltstone

color: grey

grain composition: gypsum

sedimentary textures: poorly sorted, medium to fine sand, swallow tail and lenticular crystal

shapes,

sedimentary structures: none

fossils: fibrous organics, seeds,

diagenetic features: gypsum, carbonate cement

other: cement reacts with $\mathrm{HCl}$

unit: missing

depth (ft): $64.0-63.0$

unit: 77

depth (ft): $63.0-59.6$

lithology: gypsum sandstone and siltstone

color: grey

grain composition: gypsum

sedimentary textures: minimally abraded lenticular grains, abraded blocky grains

sedimentary structures: none

fossils: fibrous organics, seeds

diagenetic features: carbonate cement

other: cement reacts with $\mathrm{HCl}$ 
unit: 78

depth (ft): $63.0-57.8$

lithology: gypsum sandstone and siltstone

color: white

grain composition: gypsum

sedimentary textures: bimodal grain size distribution, medium and fine grains, angular - blocky

grains minimally abraded lenticular grains, abraded blocky grains

sedimentary structures: none

fossils: fibrous organics, seeds

diagenetic features: carbonate cement, cluster of displacive

other: cement reacts with $\mathrm{HCl}$

unit: 79

depth (ft): $57.8-47.9$

lithology: gypsum sandstone and siltstone

color: white

grain composition: gypsum

sedimentary textures: poorly sorted, angular clear medium grains, fine blocky frosted grains

sedimentary structures: suspect root traces

fossils: none

diagenetic features: carbonate cement, cement patchy in places

other: reacts more strongly with $\mathrm{HCl}$ moving up

unit: 80

depth (ft): $47.9-47.4$

lithology: carbonate mudstone

color: grey

grain composition: gypsum grains scattered throughout, more abundant at top of unit

sedimentary textures: fine to coarse gypsum sand, angular to rounded, frosted to clear

sedimentary structures: suspect root traces

fossils: sparse plant piece

diagenetic features: none

other: reacts with $\mathrm{HCl}$

unit: 81

depth (ft): $47.9-47.4$

lithology: gypsum sandstone and siltstone

color: $\tan$

grain composition: gypsum

sedimentary textures: bimodal grain size distribution, medium angular grains, frosted blocky

fine grains, suspect swallowtail shapes

sedimentary structures: suspect root traces

fossils: some seeds near top of unit

diagenetic features: carbonate cement

other: patchy reaction with $\mathrm{HCl}$ 
unit: 82

depth (ft): $43.2-42.4$

lithology: gypsum sandstone and siltstone

color: white

grain composition: gypsum

sedimentary textures: bimodal grain size distribution, medium angular grains, fine frosted

blocky grains, suspect swallowtail shapes

sedimentary structures: brown crinkly lamina defined by organic material

fossils: fibrous material, seeds

diagenetic features: $n / a$

other: $\mathrm{n} / \mathrm{a}$

unit: 83

depth (ft): $42.4-40.2$

lithology: gypsum sandstone and siltstone

color: grey

grain composition: gypsum

sedimentary textures: poorly sorted, medium and fine grains, blocky grains, few angular grains, finer and more well sorted near the top

sedimentary structures: brown crinkly lamina defined by organic material, wavy lamina

fossils: seeds

diagenetic features: carbonate cement

other: cement reacts with $\mathrm{HCl}$

unit: 84

depth (ft): 40.2 - 39

lithology: gypsum sandstone and siltstone

color: $\tan$

grain composition: gypsum

sedimentary textures: bimodal grain size distribution, fine and medium, abraded, angular -

blocky grains, fines upwards and becomes more well sorted, frosted grains

sedimentary structures: none

fossils: none

diagenetic features: carbonate cement

other: cement reacts with $\mathrm{HCl}$ 
unit: 85

depth (ft): $39.0-38.0$

lithology: gypsum sandstone and siltstone

color: light grey

grain composition: gypsum

sedimentary textures: bimodal grain size distribution, fine and coarse sand, abraded, angular blocky grains, fines upwards and becomes more well sorted, frosted grains

sedimentary structures: poorly defined beds based on grain size

fossils: organic fibrous material

diagenetic features: carbonate cement

other: cement reacts with $\mathrm{HCl}$

unit: 86

depth (ft): $38.0-36.9$

lithology: gypsum sandstone and siltstone

color: $\tan$

grain composition: gypsum

sedimentary textures: well sorted, fine sand, 2 beds composed of medium gypsum, abraded, rounded grains

sedimentary structures: poorly defined beds based on grain size

fossils: organic fibrous material

diagenetic features: carbonate cement

other: cement reacts with $\mathrm{HCl}$

unit: 87

depth (ft): $36.9-35.6$

lithology: gypsum sandstone and siltstone

color: white

grain composition: gypsum

sedimentary textures: bimodal grain size distribution, medium and fine, blocky, abraded grains, few coarse angular grains

sedimentary structures: poorly defined beds based on grain size

fossils: organic fibrous material, seeds

diagenetic features: carbonate cement

other: gradational transition with unit 86 
unit: missing

depth (ft): $34.7-33.0$

unit: 89

depth (ft): $33.0-33.5$

lithology: gypsum sandstone and siltstone

color: grey

grain composition: gypsum

sedimentary textures: well sorted, fine grains, blocky and abraded

sedimentary structures: root traces, suspect cross lamina

fossils: none

diagenetic features: carbonate cement

other: cement reacts with $\mathrm{HCl}$

unit: 90

depth (ft): $33.5-29.9$

lithology: gypsum sandstone and siltstone

color: white

grain composition: gypsum

sedimentary textures: poorly sorted, silt to coarse sand, some bimodal grain size distribution, platy and blocky grains, angular to subrounded

sedimentary structures: cross lamina, imbrication of grains

fossils: none

diagenetic features: carbonate cement

other: cement reacts with $\mathrm{HCl}$

unit: 91

depth (ft): $29.9-29.0$

lithology: gypsum sandstone and siltstone

color: white

grain composition: gypsum

sedimentary textures: moderately sorted, fine sand grains, few platy grains

sedimentary structures: wavy lamina

fossils: organic fibers, seeds

diagenetic features: carbonate cement

other: cement reacts with $\mathrm{HCl}$ 
unit: 92

depth (ft): $29.0-28.2$

lithology: gypsum sandstone and siltstone

color: white

grain composition: gypsum

sedimentary textures: well sorted fine sand

sedimentary structures: none

fossils: organic fibers

diagenetic features: carbonate cement

other: cement reacts with $\mathrm{HCl}$

unit: 93

depth (ft): $28.2-28.5$

lithology: gypsum sandstone and siltstone

color: white

grain composition: gypsum

sedimentary textures: some bimodal grain size distribution, mostly well sorted, few platy

grains, frosted, blocky grains

sedimentary structures: none

fossils: organic fibers

diagenetic features: carbonate cement

other: cement reacts with $\mathrm{HCl}$ 


\section{Appendix 2}

\begin{tabular}{|c|c|c|c|c|c|c|c|c|c|c|c|c|c|c|c|c|c|c|c|c|c|c|}
\hline 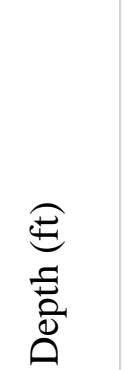 & 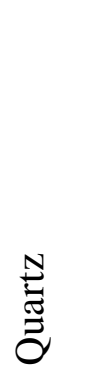 & 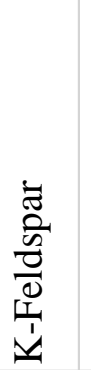 & $\begin{array}{l}0 \\
\frac{0}{0} \\
\frac{0}{0} \\
\frac{\pi}{00} \\
\frac{\pi}{2}\end{array}$ & $\frac{\stackrel{\mathscr{n}}{\tilde{U}}}{\tilde{U}}$ & 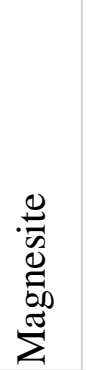 & 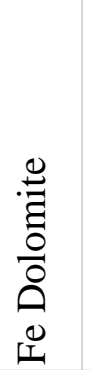 & 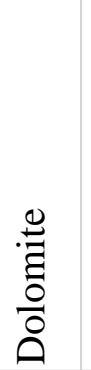 & 莺 & 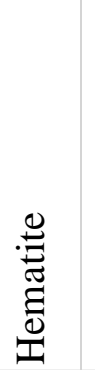 & 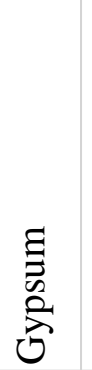 & 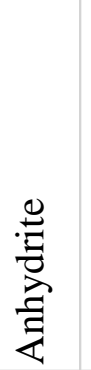 & 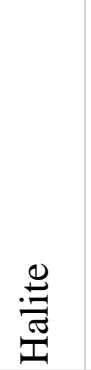 & 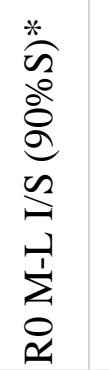 & 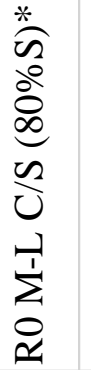 & 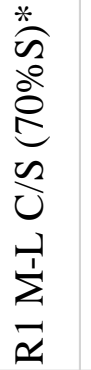 & 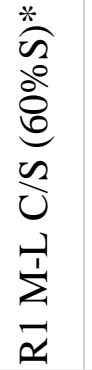 & 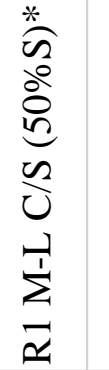 & 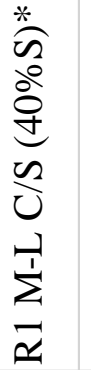 & 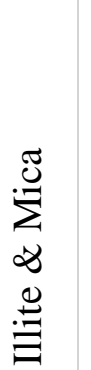 & 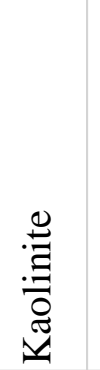 & 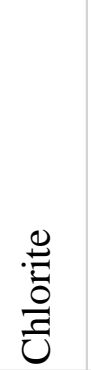 & $\underset{6}{\stackrel{2}{E}}$ \\
\hline 190.2 & 10.9 & 5.5 & 5.4 & 4 & 0 & 0 & 0.7 & 0 & 0 & 1.1 & 0 & 0 & 52.9 & 0 & 0 & 0 & 0 & 0 & 11.1 & 7.2 & 1.2 & 100 \\
\hline 122.4 & 14.2 & 7.9 & 6.7 & 1.4 & 0 & 0 & 1.1 & 1.6 & 0 & 1.6 & 0 & 1 & 41.8 & 0 & 0 & 0 & 0 & 0 & 14.2 & 7.1 & 1.4 & 100 \\
\hline 57.1 & 3.7 & 5.2 & 6.5 & 0 & 51.7 & 0 & 1.9 & 0 & 0 & 19 & 0 & 0 & 2.9 & 0 & 0 & 0 & 0 & 0 & 6.7 & 0.5 & 1.9 & 100 \\
\hline
\end{tabular}

*Mixed-Layer Clay Minerals:

R0 M-L I/S (90\%S) - R0 (Random) Ordered Mixed-Layer Illite/Smectite with 90\% Smectite Layers

R0 M-L C/S (80\%S) - R0 (Random) Ordered Mixed-Layer Chlorite/Smectite with 80\% Smectite Layers

R1 M-L C/S (70\%S) - R1 Ordered Mixed-Layer Chlorite/Smectite with 70\% Smectite Layers

R1 M-L C/S (60\%S) - R1 Ordered Mixed-Layer Chlorite/Smectite with 60\% Smectite Layers

R1 M-L C/S (50\%S) - R1 Ordered Mixed-Layer Chlorite/Smectite with 50\% Smectite Layers

XRD data for samples. Analysis run by K-T Geoservices. 